University of Rhode Island

DigitalCommons@URI

Open Access Dissertations

1965

\title{
INHIBITION OF ACETYLCHOLINESTERASE BY COPPER CHELATES
}

Ernest Mario

University of Rhode Island

Follow this and additional works at: https://digitalcommons.uri.edu/oa_diss

\section{Recommended Citation}

Mario, Ernest, "INHIBITION OF ACETYLCHOLINESTERASE BY COPPER CHELATES" (1965). Open Access

Dissertations. Paper 157.

https://digitalcommons.uri.edu/oa_diss/157

This Dissertation is brought to you for free and open access by DigitalCommons@URI. It has been accepted for inclusion in Open Access Dissertations by an authorized administrator of DigitalCommons@URI. For more information, please contact digitalcommons-group@uri.edu. 


\section{INHIBITION OF ACETYLCHOLINESTERASE \\ BY COPPER CHEIATESS \\ BY}

ERNEST MARIO

A THESIS SUBMITTED IN PARTIAL FULFTLLMENT OF THE REQUTREMENTS FOR THE DEGREE OF

DOCTOR OF PHILOSOPHY

IN

PHARMACY

UNIVERSITY OF RHODE ISLAND

1965 


\section{DOCTOR OF PHILOSOPHY THESIS \\ OF}

ERNEST MARIO

\section{Approved: \\ Thesis Committee: \\ Chairman}

Dean of the Graduate School

UNIVERSITY OF RHODE ISLAND 1965 
ACKNOWLEDGMENTS

The author wishes to express his sincere thanks and appreciation to Dr. Sanford M. Bolton, for his continual support, original thinking and patience during the preparation of this thesis. Further, the author would like to acknowledge the able assistance of Dr. James C. Price in setting up the instrumentation necessary for data measurements. There were many others who contributed to this paper including Dr. William E. Ohnesorge, who interpreted spectral data and Dr. Scott Mackensie, who interpreted organic inductive mechanisms. 
TABLE OF CONTENTS

CHAPTER

PAGE

I. INTRODUCTION. . . . . . . . . . . . . 1

II. EXPERTMENTAL. .................... 13

Reagents. . . . . . . . . . . 13

Description of pH STAT Instrumentation. . . . . . 14

Free Cupric Ion Determination ......... 15

Chelation Studies........... 17

Enzyme Inhibition Studies . . . . . . . . 18

Derivations and Calculations. . . . . . . . 19

III. RESULTS AND DISCUSSION. . . . . . . . . . 26

Free Cupric Ion Determinations. . . . . . . 26

Ligand Dissociation Constants . . . . . . . 29

Stability Constants .......... . . 29

AOH. . . . . . . . . . . . . 32

$\mathrm{AH}$. . . . . . . . . . . . 36

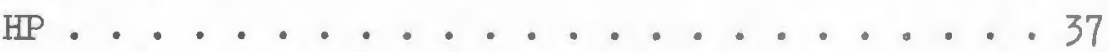

Inhibition Studies. . . . . . . . . . 44

Inhibition by Free Cupric Ion. . . . . . . . 44

Inhibition by Free Ligand. . . . . . . . . 46

Inhibition by the AOH System . . . . . . 4 47

Inhibition by the AH System. . . . . . . . 57

Inhibition by the HP System. . . . . . . . 66

Correlation of the Inhibition Studies . . . . . 71

Relation of Inhibition to Stability Constants. . 71 
Relation of Inhibition to Charge ...... 73 pH Effects on Inhibition . . . . . . . 73 Relation of Coordination Vacancies and Inhibition. 75 Relation of Configuration and Inhibition . . . 75 IV. SUMMARY . . . . . . . . . . . . 77 BIBLIOGRARHY . . . . . . . . . . . 79 APPENDIX A. Multiple Regression Approach. . . . . . 82 APPENDIX B. Fortran IV Listing for Quadratic Solution . . 83 APPENDIX C. Fortran IV Listing for Cubic Solution . . . 84 APPENDIX D. $\propto$ Determinations According to the Method Described by Maengwyn-Davies and Friedenwald (18).......... 86 


\section{LIST OF FIGURES}

FIGURE

PAGE

1. Calibration Curve for Free Cupric Ion Versus

Diffusion Current . . . . . . . . . . 27

2. Calibration Curve for Free Cupric Ion Versus

Absorbance. . . . . . . . . . . . 28

3. Titration of 1,3 Diaminopropanol-2(diHCl) in the

Absence of, and in the Presence of, $\mathrm{Cu}^{++}$Ion. ... 33

4. Titration of 1,3 Diaminopropanol-2(diHCl) in the

Absence of, and in the Presence of, $\mathrm{Cu}^{++}$Ion. . . . 34

5. Titration of 1,3 Diaminopropane(diHCl) in the

Absence of, and in the Presence of, $\mathrm{Cu}^{++}$Ion. . . . 38

6. Titration of 1,3 Diaminopropane(diHCl) in the

Presence of $\mathrm{Cu}^{++}$Ion. . . . . . . . . . 39

7. Titration of Hydroxy-L-Proline (HCI) in the Absence

of, and in the Presence of $\mathrm{Cu}^{++}$Ion ....... . 41

8. Titration of Hydroxy-L-Proline(HCl) in the Presence

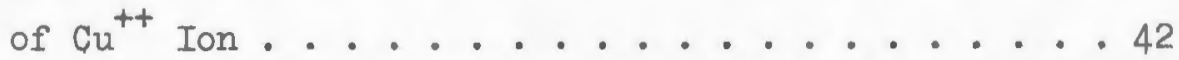

9. Formation Functions of Copper Chelates of $\mathrm{AH}$ and HP . . 45

10. Comparison of Inhibition by 1-1 AOH Chelate at

Various $\mathrm{pH}$ Values . . . . . . . . . . 50

11. Comparison of Inhibition by 1-1 $\mathrm{AOH}$ Chelate at

Various pH Values... . . . . . . . . 52

12. Analysis of Inhibition by 1-1 $\mathrm{AOH}$ Chelate at

$\mathrm{pH} 8.5$ Using $1 /(\mathrm{s})$ Values............ 55 
13. Analysis of Inhibition by 1-1 AOH Chelate at $\mathrm{pH} 8.5$ Using (I) Values. . . . . . . . . 56

14. Inhibition by $1-1$ and 2-1 $\mathrm{AH}$ Chelates at $\mathrm{pH} 8.0$. . . 58

15. Analysis of Inhibition by 1-1 AH Chelate at $\mathrm{pH} 8.0$ Using $1 /(\mathrm{s})$ Values. . . . . . . . . . 60

16. Analyais of Inhibition by 1-1 AH Chelate at $\mathrm{pH} 8.0$ Using (I) Values ............ . . 61

17. Inhibition by 1-1 AH Chelate in Several LigandMetal Ratios at $\mathrm{pH}$ 8.0............ 64

18. Inhibition by $1-1$ and 2-1 $\mathrm{AH}$ Chelates at $\mathrm{pH} 8.5 . . .65$

19. Inhibition by 1-1 HP Chelate in Several LigandMetal Ratios at $\mathrm{pH} 8.25$.......... 68 
LIST OF TABLES

TABLE

PAGE

I. Ligand Dissociation Constants. . . . . . . 30

II. Stability Constants for Ligand Interactions with $\mathrm{Cu}^{++}$............... 31

III. Calculated Free Ligand Species at Various $\bar{n}$ Values for the $\mathrm{AH}-\mathrm{Cu}^{++}$Interaction......... 40

IV. Calculated Free Ligand Species at Various $\bar{n}$ Values for the $\mathrm{HP}-\mathrm{Cu}^{++}$Interaction. . . . . . 43

V. Inhibition by 1-1 $\mathrm{AOH}$ Chelates in a 2.1-1 LigandMetal Ratio Solution . . . . . . . . 4 48

VI. Inhibition by 1-1 AOH Chelate in a 2.2-1 LigandMetal Ratio Solution at $\mathrm{pH} 8.5$ with Varying Substrate Concentrations . . . . . . . 53

VII. Inhibition by 1-1 $\mathrm{AH}$ Chelates in a 2.1-1 LigandMetal Ratio Solution at $\mathrm{pH} 8.0$ with Varying Substrate Concentrations . . . . . . . 62

VIII. Inhibition by 1-1 $\mathrm{AH}$ Chelate in 2.2-1 and 2.3-1 Ligand-Metal Ratio Solution at $\mathrm{pH} 8.0$ with a Substrate Concentration of $1.22 \times 10^{-3} \mathrm{M} \ldots 63$

IX. Inhibition by 1-1 $\mathrm{HP}$ Chelate in Several LigandMetal Ratio Solutions at $\mathrm{pH} 8.25$ with a Substrate Concentration of $1.22 \times 10^{-3} \mathrm{M}$....... 70

X. Relation of Chelate Stability Constants $\left(\mathrm{K}_{1}\right)$ to Ihibition Constants $\left(\mathrm{K}_{\mathrm{I}}\right)$. . . . . . . 72 


\section{ABSTRACT}

As part of a study to investigate metal chelates as possible inhibitors of acetylcholinesterase, ccpper chelates of 1,3 dianinopropanol-2, 1,3 diaminopropare, and hydroxy-L-proline are examined. Since the chelate solutions cuntair mixtures of species in equilibrium, it is necessary to calculate the corcentrations of pertinent species under experimertal conditions. Equations are derjved which can be used to calculate the concertrations of individual species in an equilibriam mixture of lipand an . pper urder pued ronditions of concentration and $\mathrm{pH}$ with the ald of an IBM 14 ic computer. Initial measurements of reaction velocity of enzyme-substrate breakdown to enzyme plus acid products, are made by observing the speed of $\mathrm{pH}$ drop with the aid of' a Beckman Automatic 'Titrator. Selection of equilibrium $\mathrm{pH}$ values and legand-metal ratios is dependent on the formation constants calculated for each system. Enzyme kinetıc studies are used in an effort to determine the nature of the irnhibition of acetylcholinesterase.

It is found that (a) 1-1 ligand-copper chelate inhiblt the acetylcholinesterase system, (b) tree cupric ion may inhingt, the enzyme system if concentrations greater than $1 \times 10^{-6} \mathrm{M}$ are present in the equilibrium mixture, (c) coordination vacancies on the metal ion are necessary prerequisites for inhibitiur, (d) 1-1 ligandcopper chelates of 1,3 dianinopropanol inhibit the enzyne in an essentially "competitive" manner, (e) 1-1 ligand-copper chelates of 1,3 diaminopropane inhibit the erryme in an essentially "ioncompetitive" manner, (f) 1-1 ligrand-ocopper chelates of hydruxy- 
L-proline exhibit a "yield value" (or critical concentration requirement) before any inhibition occurs, and $(g)$ the equilibrium $\mathrm{pH}$ of the experiments affects both the extent and nature of the inhibition. 


\section{INTRODUCTION}

In recent years, the study of enzyme inhibition has gained widespread attention. Enzyme activity may be affected by a variety of factors such as $\mathrm{pH}$ ohanges (1) and chemical or physical interference $(2,3)$. For example, recent findings concerning the use of ultraviolet light to impair the succinate oxidase enzyme system have been reported by several investigators (4-7). Unfortunately, in most instances, the exact mechanism(s) behind the inhibition of enzymes remains obscure. This is not unexpected since enzymes are, by nature, extremely complex molecules (8).

Acetylcholinesterase is a typically complex enzyme. It has a protein-like structure with a molecular weight of approximately three million, and is found in erythrocytes, nervous and electrical tissue (9). Acetylcholinesterase, in vivo; hydrolyzes the ester, acetylcholine, into choline andacetic acid and the following mechanism has been suggested (8):

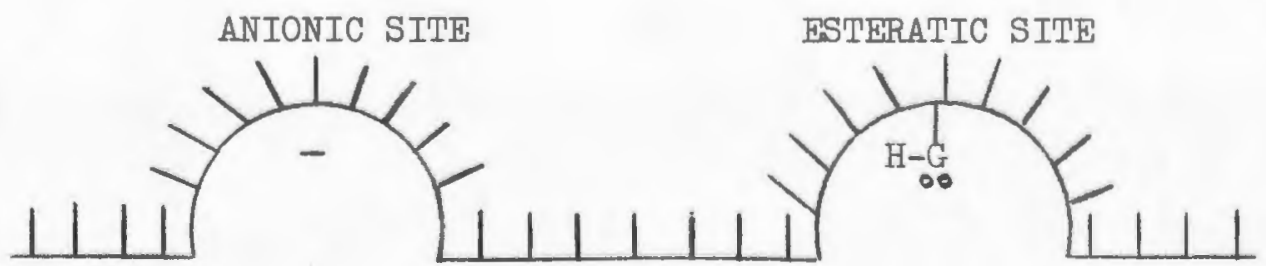

ACETYLCHOLINESTERASE

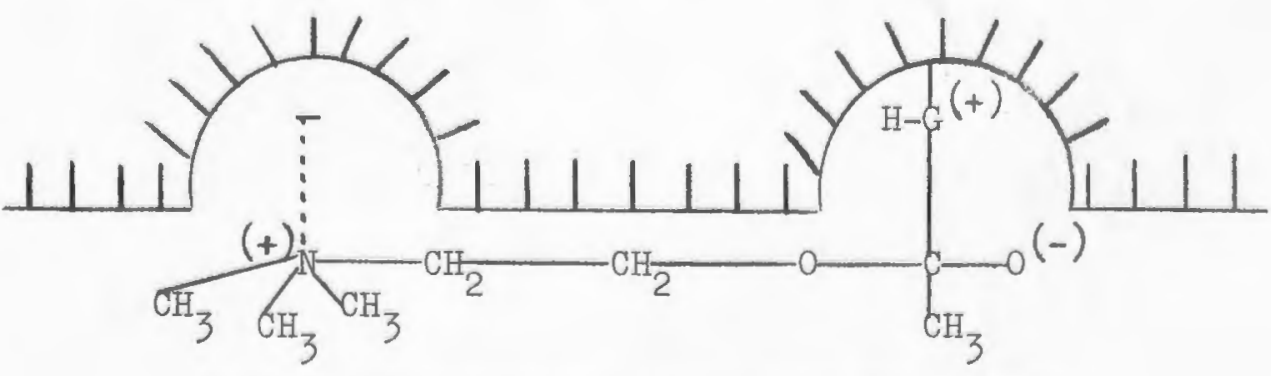


The complex formed dissociates to yield erryme plus products. lhe model has two active siles io which the substrate may attach, an anionic site that attracts the quarternary ritiroger group of acetylcholine and an esteratic site which reacts with the carbonyl moiety a tie titer. Wilson arta Bergmanr (10) ruve found that acetylcholinesterase exhibits optimun artivity at pH 8.3. Above or below this pH, the ecrivity of the eneyme

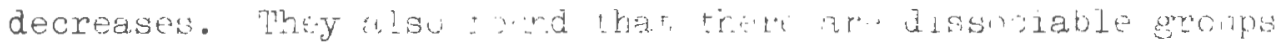
near the active sites which have pK valus at 7.2 and 9.5. These dissociable groups can interact or bind with various substrates resultine in enzyme activity al pH valuss above ard below the optimum vallie of $8 . \overline{3}$.

Prostigmine and eserine are two classical examples of acetylcholinesterase irhibitors. Prostizmine contains a quartes:nary ammonium uroup which is charged throughout the pH range of enzyme activity. Fserine, on the other havd, contains a basio group with a pK value rear 8.2. When fjxta concentratiiris ut these inhibitors were studied at different pH values, the inhibitory effect of prostigmine was constant; whereas the inhibitory effect of eserine was higher cr the acid side of pH

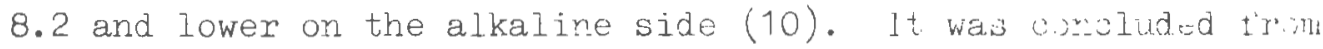
this information that the inhibitors attach to the anionic sitw and a cationic group ir the inhibitor is essentual for jubibitar. to take place (11). This conclusing was further substantiatod by observirg the eifects ot wjmple amm am compounds on the 
activity of acetylcholinesterase. Wilson (12) showed that the inhibition of acetylcholinesterase by simple ammonium compounds is dependent on the charge of the ammonium moiety. At high $\mathrm{pH}$ values, where there is less of the cationic form, the inhibitory effects of these ammonium compounds are less pronounced. Tris reduction of inhibitory effect, as $\mathrm{pH}$ is increased, illustrated a significant point. Since there is a dissociable group on the enzyne surface, near the active site, with a pK value of 9.3 , the influence of the positively charged ammonium group might be expected to be more apparent when this $\mathrm{pH}$ is approached. The fact that the inhibition falls off as $\mathrm{pH}$ is raised, indicates that the ammonium moiety is binding not to an adjacent dissociable group, but, rather, directly to the active anionic site on the enzyme surface. Furthermore, if the binding occurs only at the active site, the inhibition will appear as "competitive", (i.e., the inhibitor and the substrate will vie for the same site) when the data are analyzed using conventional theoretical enzyme kinetic theory methods (13-17). If the binding occurs at adjacent sites, the inhibition is often found to be "non-competitive". Unfortunately, most inłibitors do not show a sharp delineation between "competitive" and "non-competitive" inhibition, but exhibit instead, a combination of both types (18).

The present investigation was undertaken in ar attempt to elucidate the nature of enzyme inhibition by metallo-organic 
compounds. It was felt that the chelates might act as irihibitors due to the presence of the positively charged metallic ion. Since the interaction of chelates with the enzyme may be related to chelate properties, it would be of value to review some of the pertinent chemistry of chelate compounds. The term "chelate", first introduced by Morgan and Drew (19), is taken from the Greek term chele, meaning crab's claw. The analogy Is obvious, since roth a claw arid a chelating agent or ligand may hold an object (i.e., the metal ion) through two or more points of attachment. These attachments are the result of ligand molecules successfully competing with the water molecules normally associated with metal ions. The number of water molecules associated with a given metal ion under known conditions is referred to as the coordination number of the metal. The binding forces between ligand molecules and metal ions may be electrostatic in nature (i.e., the attraction of a positive metal ion for a negative ion or the attraction of a positive metal ion for the negative portion of the dipole of a neutral molecule such as water). On the other hand, the binding may be primarily covalent in nature with eleotron-pair bonds accounting for the major portion of the affinity. Whether the binding is primarily electrostatic, primarily covalent, or something intermediate, the function of the ligand is always that of donating electrons to the metal (20). The overall net charge of the chelate molecule will depend on the nature of the ligand 
molecule and the type of binding which occurs. If the ligand forms a stable, water soluble metal chelate, it is called a sequestering agent. This sequestering property can be shown by elevating the $\mathrm{pH}$ of the ligand-metal mixture and observing the presence or absence of metal hydroxide precipitation. If no precipitate appears at elevated $\mathrm{pH}$ values, the metal is said to De "sequestered." When one ligarid molecule contairs sulficient electron donor groups to saturate all the coordinating positions or the metal ion, a single, stable 1-1 ligand-metal chelate is usually formed. The interaction of ethylenediaminetetraacetic acid with several metal ions as described by Schwarzerbach and coworkers (21-23) is a good example of a metal chelate species containing a ligand-metal ratio of unity. If, however, the introduction of one ligand molecule does not saturate all the coordinating positions on the metal ion, it is possible in certain cases to bind one or more additional ligand molecules to the same metal ion and still retain solubility of the chelate. The formation of higher ligand-metal ratios occurs in a stepwise manner not dissimilar to the dissociation of protons from a polyprotic acid. A typical example of stepwise chelate formation has been reported by Chaberek and Martell (24) and concerns the interaction of imino-diacetic acid with $\mathrm{Cu}^{++}, \mathrm{Ni}^{++}$, and $\mathrm{Co}^{++}$ions. The nature of the interaction of this acid with 
metal ions was interpreted from the curves obtained by titration of various ligand-metal mixtures with stardard base. The formation or stability constants of the 1-1 and 2-1 ligand-metal species can be calculated using a direct algebraic method outlined originally by Schwarzenbach and co-workers $(21,25)$. It should be noted that this algebraic treatment of the data is only approximate. Certain assumptions are made which are not strictly accurate and the true values can be obtajned unly through the use of a series of approximaticns (26). Employing this algebraic technique, Schwarzenbach and co-workers $(23,27$, 28) have determined the chelating tendencies of several alkaline earth metals.

Bjerrum (29) introduced a method of calculating formation constants which relies on the experimental determination of free ligand concentrations at various points during the titration of a ligand-metal mixture. He also introduced the function $\bar{n}$ which is defined as the average number of ligand molecules bound per mole of metal. This $\bar{n}$ function may be expressed mathematically as follows:

$$
\bar{n}=\frac{\left(M L+2\left(M_{2}\right)+\ldots \ldots+n\left(M L_{n}\right)\right.}{(M)+(M L)+\left(M L_{2}\right)+\ldots . .+\left(M L_{n}\right)}
$$

With a plot of $\bar{n}$ versus the negative log of free ligand concentration, the formation constants may be obtained directly (see Experimental). However, this method is also approximate unless the numerical difference between the successive corstants 
is large. If the numerical difference is small, the true values for the successive formation corstants may be determired by an iteration procedure (see Appendıx A)。

As previously mentioned, the iritial purpose of this series of investigrations was to observe the eifects ol metalloorganic chelate compouras on tre avetylcholinesterase-acetylcholine system. To this end, Bclton and Beckett (30) prepared $\mathrm{Cu}^{++}$chelates of pynidine-z-aldaxime. In this preliminary stidy, it was felt that metal chelates, having a positive charge, would bind directly to the active anionic sites on the enzyme surface and inhibit enzyme activity in a "oompetitive" namer. Further, if the enzyme was poisoned with orgaric phosphates such as DFP, the chelated species might act as an encyme reautivator by displacing the poison through a competitive process. Also, certain chelates have been reported which, in fact; increase the rate of decomposition of organic phosphate poisons $(31,32)$ and pyridine-2-aldoxime metriodide has been shown by wilson ( $5 ;$ : to reactivate the phosphate poisoned acetylcholinesterase enzyme. Thus the choice of pyridine-2-aldoxime chelates as potential enzyme reactivators seemed reasonable.

The results of this preliminary stidy showed that metal chelates of pyridine-2-aldoxime were pcor reactivaturs of phosphate poisored acetylcholiresterase. The abserce of gond rteactivation properties was attributed to steric factors. In other words, the confingration of the alduxime chelates appar- 
ently was not as stereospecific for the active sites on the enzyme surface as the aldoxime-methiodide structure. Nevertheless: an interesting observation recorded was that the aldoxime-copper chelate species, ir some way, exerted an inhibitory effect on the activity of acetylcholinesterase. Unfortunately, the exact composition of the pyridine-2-aldoxime$\mathrm{Cu}^{++}$chelate is in doubt (34). Repeated efforts to elucidate the exact ratio or ligand to metal in the chelated species were unsuccessful.

Since one of the main purposes of this investigation was to correlate chelate charge and configuration with infibitory activity, it was essential that the nature of the ligand-metal interactions be known. Because of this requirement regarding the nature of the ligand-metal interaction, simple, well defined chelate systems were sought. In the first of a series of papers concerning inhibition of acetylcholinesterase by metal chelates, Bolton (35) used the $\mathrm{Cu}^{++}$chelates of siycine and ethylenediamine. The choice of these two licrands was prompted by the fact that the chelation properties of these ligands have been extensively studied (36). Using a set of derived equations (34), Bolton was able to determine the precise concentrations of all species present in the ligand-metal mixture at specific pH values. On the basis of his observations, Bolton concluded that: (1) Both 1-1 ligand-metal species and free cupric ior may act as inhibitors; (2) 2-1 ligand-metal species did not 
inhibit significantly, possibly due to steric factors; (3) the exact site of birding could not be determined on the basis of data obtained, but the anionic site or some other negatively charged site is probably involved; (4) the inhibitory influence of the chelate mixture is greater at $\mathrm{pH} 8.0$ than $\mathrm{pH} 7.0$, indicating a poseible approach to the $\mathrm{pK}$ value of the dissuciable group at the birding site (10).

In the secord paper of this seryos, Bolton (37) extended his study to include $\mathrm{Ni}^{++}$chelates of ciycine and ethylenediamine. Further, the data concermed witr the irihibition of the enzyme by the 1-1 cupric shelates were analyzed according to the method described by Friedenwald and Maengwyn-Davies (18). The conclusions reached in this second paper were as follows: (1) Both 1-1 and 2-1 ligand-metal species of $\mathrm{Ni}^{++}$chelates exhibit inhibitory activity and the 1-1 species is a stronger inhibitor than the 2-1 species; (2) the $3-1 \mathrm{Ni}^{++}$chelate spectes does not inhibit the enzyme significantly, probably because ali the coordination sites of the metal ion are saturated; (3) the inhibitory mechanism of the $1-1 \mathrm{Cu}^{++}$chelates of both glycine and ethylenediamine appears to be primarily "non-competitive" in nature, indicating that binding is not occurring at the active anionic sites; (4) the inhibitory inf'luence of free metal ion can be eliminated by working at higher pH values provided the chelate remains stable; and (5) the inhibition is more pronounced at elevated $\mathrm{pH}$ values with those chelate 
species having an overall pusitive charge, irdicating a greater affinity for charged sites available to the otelates at hign $\mathrm{pH}$ values.

The information available at tho begining of this study could be surmarized as follows: (1) Me al chelatos inhiuit the acetylcholinesterase-acetylcholine literaction; (2) available coordination sites or the metal icr are recesssey prerequisites ton inhinition; (3) gerall relate rarge has a significant effect at elevated pH valwos; (4) tho 1-1 chelate species of $\mathrm{Cu}^{++}$appears to inhibit the eruyme in a primarily "non-competitive" marmer; and (5) the irhikitory effects of free metal ion may be elimirated if the chelate stability constant is large or high pH values are used. As a continuation of the above study, we were interested in finding additional chelate systems with well-defired properties and examining their effects on the acetyloholinesteraseacetylcholine system. In viow of previons results and vur objectives, the choice of suitable lizand speeies was restricted as follows: (a) The chelate formation constants of the ligand must be of sufficient magnitude to preclude ariy interference by free metal ion; (b) a large pH range of stability is reeessary to aid in observing the relatiunship between pH and inhibition; and (c) the chelate should be completely soluble throughout the pH range employed. Approximately ter potentially useful ligand molecules were examined prior to the inhibition 
studies. In all but three cases, the compounds studied were found to be unsuitable. For example, kujic acix helates proved to be too insoluble in aqueous systems; tetramethylethylenediamine formed very woak $1-1$ ard 2-1 chelate species; and several other ethylenediamine derivatives proved to to sterically hinderea when interacted with cupwic ion, resulting in weak ligand-metal interactions. The trree ligards wrich seemed suitable for this study were 1,3 diaminuproparol-2-(AOH), 1, ; diaminopropane $(A H)$, and hydroxy-L-proline(HP). All three compounds formed water soluble chelate species with substantially large $\mathrm{pH}$ rarges of stability and formation constants of suf'ficient magriltude to preclude free metal ion interference. The nature of the interaction of $\mathrm{AOH}$ with $\mathrm{Cu}^{++}$was iri dout $(38,39)$, and the interaction was studied in some detail. Attempts to duplicate previously published results were unsuccessful. It was found, from on studies, that the interaction of $\mathrm{AOH}$ and $\mathrm{Cu}^{++}$resulted in a stable 1-1 ligand.metal species with a terdertale attachment (40). The stability constants of the interaction of $\mathrm{AH}$ with $\mathrm{Cu}^{++}$as reported by Schwarzenbach and co-workers (41), were reproduced, within experimental error, in our laboratory. The inhibition caused by the two homologues ( $\mathrm{AOH}$ and $\mathrm{AH}$ ) could be compared at identical $\mathrm{pH}$ values because they were both stable and soluble within the limits of our studies and the contribution of charge and cocrdination site vacansies to inhibitoly activity could be observed. 
The interactions of the (HP)-Cu+ ${ }^{++}$helate were determined and compared favorakly with published results $(42,43)$. This ligand was chosen because of the prestrce of a free hydroxyl group in the chelated molecule. A three dimensional scale model showing the approximate positions of the active sites ch acetylcholinesterase was prepared usirét available infermation (8), and the model was compared with the possible configurations

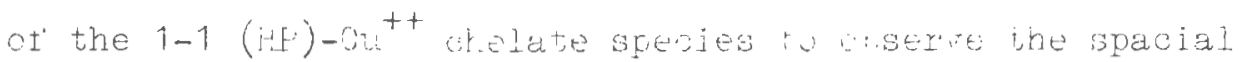
allignment and direction of the fres hydroxy roup. It appeared that the hydroxy group was directed towards the esteratio site on the enzyme ard it was felt that this potentially significant stereospecificity might result in increased zribibition. 


\section{EXPERTMENTAL}

\section{Reagents}

Analytical reagent grade $\mathrm{Cu}\left(\mathrm{NO}_{3}\right)_{2}$ was used as the source of metal ion and the solutions prepared were standardized according to the chelatometric titration method described by Wilson and Wilson (44) using murexide as an indicator. The substrate, acetylcholine iodide, was obtained in pure form from Nutritional Biochemicals Corporation. The unbuffered physiological solution used as the diluent in all experiments, was prepared by dissolving 0.9 per cent analytical reagent grade sodium chloride and 0.0567 per cent magnesium nitrate in double distilled water. Acetylcholinesterase was obtained from Nutritional Biochemicals Corporation and a stock solution of $60 \mathrm{mg}$ of the enzyme in $100 \mathrm{mls}$ of diluent was used for the experimental runs. It was not essential to know the precise purity of the enzyme material since comparative velocity studies were made at the beginning and end of each series of runs. The enzyme solution, stored in a refrigerator, was allowed to stand for three days, after which time its activity remained relatively constant for at least three weeks.

The 1,3 diaminopropanol-2(AOH) and 1,3 diaminopropane (AH) ligands were obtained in the free amine state from Aldrich Chemical Corporation ${ }^{2}$. Since the di-HCl salts of these two

1Nutritional Biochemicals Corporation, Cleveland, Ohio.

${ }^{2}$ Aldrich Chemical Corporation, 2371 North 30th Street, Milwaukee, Wisconsin. 
ligands were used in the chelation studies, metheds were sought to obtain these salts in pure form. The di-HCl salt of AOH was prepared by dissolving the impure dianire species in exsess concentrated hydrochloric acid, reagent prade, ilash evaporating to dryness, and recrystallizing several times from methanolethanol mixtures. The di-HCl salt of $A H$ was prepared ir. a similar manner, but the recrystallization step required a methanol-ethanol-water mikure tor hest reslits. The hydraxy-Lproline(HP) ligand was obtained ir pure form tam liatritional Biochemical Corporation and the mon-hydrowioride salt of this ligand was prepared in a marter Identical to that for ihe $\mathrm{AH}$ ligand. The melting poirts of these salts is accompanied by decomposition and, therefore, their pur.ty was cheoked by tit.rations with standard base and subsequent comparisons of literature $\mathrm{pK}_{\mathrm{a}}$ vlaues, wher available (see Results).

\section{Description of $\mathrm{pH}$ STAT Instrumentation}

Because ore of the primary purposes of thjs sthdy was tin effect of $\mathrm{pH}$ on inhibitior, an accurate means of measuring $\mathrm{pH}$ throughout the reaction process was sought. Furthermore, it was essential to the success of the experiments that a predetermined $\mathrm{pH}$ value be held relatively constant when measurementos were taken. The importance of this requirement will become more apparent when the general procedure is described. Suftive it to say, at this point, that an extremely sensitive pH-STAI 


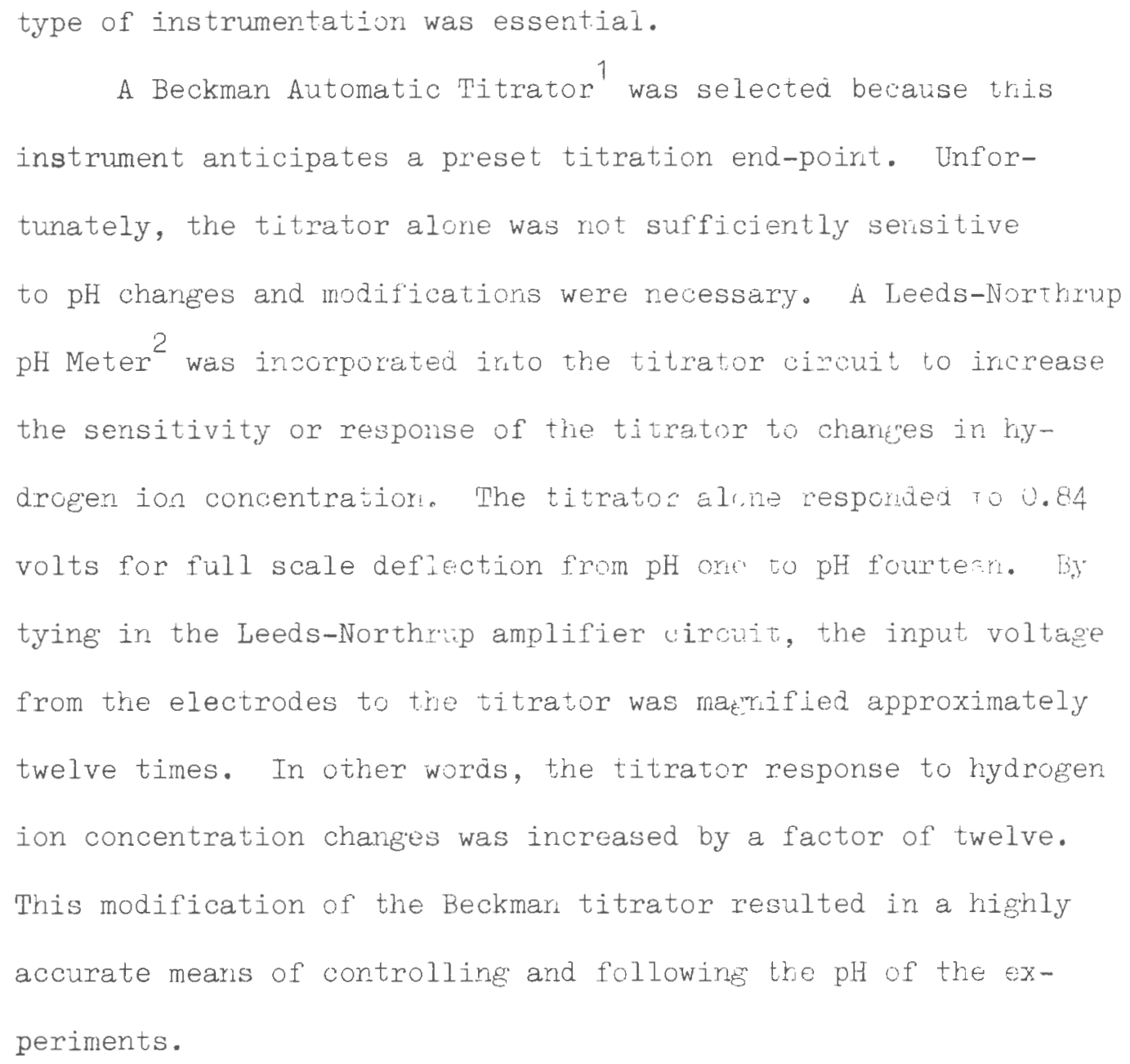

${ }^{1}$ Beckman Instruments Ine., 2500 Harbor Boulevard, Fullert...., California.

2Leeds-Northrup Company, 4901 Stentor Avenue, Fhiladelpina, Pennsy Ivania. 
Initially, an attempt, was made to determine tre precise amount of cupric ion that would bird tu a fixed conentration of enzyme. A Sargent Polarograph, model XV ${ }^{1}$, was used to prepare a calibration curve for various free cupric ion concentrations (i.e., a plot of diffusion current versus $\mathrm{Cu}^{++}$). A ten per cent solution of enayme stock solutuch. (ideatical with the stock solution used in the jnhibition studies) was treated with

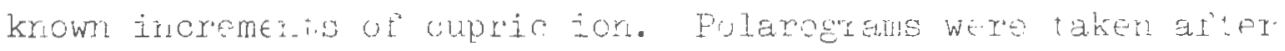
each adition writ the $i_{\text {D }}$ valies ralculated. We tura (Cu ${ }^{++}$) added was calculated after each addition takine intu conside:ation any volume charges. The concentrations of $\mathrm{Cu}^{++}$added and the anounts obtained from the calibration curve were then compared. It was anticipated that any reduction in free vut+ in the enzyme mixture could then be attribited to enzyme attachment.

Another analytical approach to the determinatin of $\mathrm{Cu}^{+i}$, described by Jenkins (45), entails the use of sodicm diethyl-dithiocarbamate as a complexing agent specific for $\mathrm{Cu}^{++}$. The complex formed in this method is colored and is fumid tu absurb in the ultraviolet rarge of the spectrum. A valibration curve was prepared by plotting absorption versus concentration of $\mathrm{Cu}^{++}$. Then, solutions of known concentration of enzyme were dialyzed for various lengths of time at constant temperature

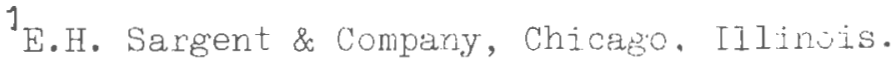


and the dialysate analyzed spectrophotometrically for free $\mathrm{Cu}^{++}$. To detect possible absorption of the metal ion on the dialysing membrane, dialysis studies were made using cupric ion solutions of known concentration in the absence of enzyme.

\section{Chelation Studies}

The acid dissociation constants for all three ligands were determined potentiometrically according to the method of Chaberek and Martell (23). To be consistent with subsequent inhibition studies, these constants were determined at $30^{\circ} \mathrm{C}$. $\pm 0.1^{\circ} \mathrm{C}$. in solutions of 0.162 ionic strength adjusted with sodium chloride, with a stream of nitrogen passing over the solution to exclude carbon dioxide. A Beckman Zeromatic pH Meter $^{1}$ was used to follow the titrations. The dissociation constants were determined directly from the titration curves taking mid-point values in the usual manner.

The extent of chelation of $\mathrm{AOH}, \mathrm{AH}$, and $\mathrm{HP}$ with $\mathrm{Cu}^{++}$ was followed potentiometrically by recording equilibrium $\mathrm{pH}$ values after addition of increments of standard base to the ligand-metal mixtures. The conditions for these determinations were the same as those described for the determination of dissociation constants. The ratio of ligand to metal in the chelate was analyzed by titration of ligand-metal solutions of various ratios (i.e., 1-1, 2-1, 3-1, etc.)--see Results.

${ }^{1}$ Beckman Instmuments Inc., 2500 Harbor Boulevard, Fullerton, Califormia. 
Enzyme Inhibition Studies

In al. inklibition studies, we $m l$ of the e.zyme stouk solution was added to a sulution of the chelate preset to the $\mathrm{pH}$ of the experiment. The adjustment of $\mathrm{pH}$ before the addition of the enzyme was essertial since the somposition of the chelate mixture is pH dependert. If, for example, tro iritial pH of the chelate solution were low, exirssive amout of free bipl.

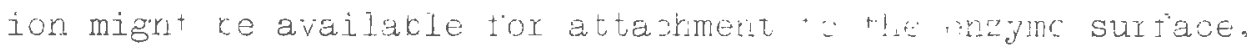

A glass, jacketed vessel of approxinately 20 mil volume: was used to contain the reaction mixture and the temperature of the system was contrulled with a Labline oirculating water bath $^{1}$. The reaction mixture was corstantly stirred using a Magnestir. A plexiglass cover, fitted to the top of the reaction vessel, contaired openirgs for the Beckman combination electrodt. the nitrogen gas inlet, and the plastic extension from the titrator buxette. The final volume of the reaction mixtures was adjusted to nine $\mathrm{ml}$ with diluent.

The enzyme and chelate were allowed to romain ir. cortaw for fifteen minutes at the preset $\mathrm{pH}$ of the experiment (except during time dependence studies) before the sunstrate (acetylcholine) was added. The firal mrentration st acotyluhtirk was $1.22 \times 10^{-3} \mathrm{M}$ for all experimerts except thise concerwed with the determination of the "competitiveress" of the inhibition (see Results).

\footnotetext{
${ }^{1}$ Labline Instruments Iru, Chjcaro, Illabis.
} 
The values of $\mathrm{Vo} / \mathrm{V}$, (velocity with no inkibitor)/(velocity with inhibitor), were taken as the relative t.jmes necessary to consume $0.30 \mathrm{ml}$ of base during which the hydrulysis was linear as a function of time.

The velocity of the rydrolysis reantion corresponded to the time required to use $0.30 \mathrm{ml}$ of base, provlded the relationship between base used and time remained Iinear. Tn certain cases, where the relucity was vely sliw, it was necessary to extrapolate the line to $0.30 \mathrm{ml}$ of base. Irie value of Vo was checked at the begiming and end of each series of experiments to ensure that enzyme activity remained constant.

Derivations and Calculations

The dissociatior: cunstants for all three ligands, wj th the exception of the dissociation of the ethanolic hydrogen in $\mathrm{AOH}$, were obtained direotly from the titration data. Ghe

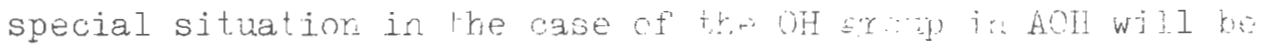
discussed in detail in the Results.)

By titrating solutions containing vari we ligand-metal ratios with standard base, it was possible tr calculate the chelate stability constants for all three livands accorlirec to the method described by Bjerrum (29). A brief description of this method for a diprctio ligand-metal interaction. with successive formation constants correspondirng to 1-1 and 2-1 chelate species, is as follows (disredardirg the charge of the species). The acid dissuciatron constants ard the cne lat." 
stability constants are defined as fillows:

$$
\begin{aligned}
& \mathrm{H}_{2} \mathrm{~L} \rightleftharpoons \mathrm{HL}+\mathrm{H} \quad, \quad \mathrm{ka}_{1}=\frac{(\mathrm{HL})(\mathrm{H})}{\left(\mathrm{H}_{2} \mathrm{~L}\right)} \\
& \mathrm{HL} \rightleftharpoons \mathrm{L}+\mathrm{H} \quad, \quad \mathrm{ka}_{2}=\frac{(\mathrm{H})(\mathrm{L})}{(\mathrm{HL})} \\
& \mathrm{M}+\mathrm{L}_{+} \Longrightarrow \mathrm{NI}_{1} \quad, \quad \mathrm{~K}_{1}=\frac{(\mathrm{ML})}{(\mathrm{M})(\mathrm{L})} \\
& \mathrm{ML}+\mathrm{I} \rightleftharpoons \mathrm{ML}_{2} \quad, \quad \mathrm{~K}_{2}=\frac{\left(\mathrm{ML}_{2}\right)}{(\mathrm{ML})(\mathrm{L})}
\end{aligned}
$$

where $\mathrm{H}_{2} \mathrm{~L}_{\text {r }}$ represents undissociated ligand and $M$ represents meta]. ion.

Also,

$$
\mathrm{L}_{\mathrm{T}}=(\mathrm{L})+(\mathrm{HL})+\left(\mathrm{H}_{2} \mathrm{~L}\right)+(\mathrm{ML})+2\left(\mathrm{ML}_{2}\right)
$$

and $M_{\mathrm{P}_{1}}=(M)+(M L)+\left(M L_{2}\right)$

where $\mathrm{L}_{\mathrm{T}}$ represents total ligand in the system ara

$$
\mathrm{M}_{\mathrm{T}} \text { represents total metal in the system, }
$$

Let a represent moles of $\mathrm{OH}$ added/mole of ligand. Tiker a $\left(\mathrm{L}_{\Gamma \Gamma}\right)$ will equal the number of moles of base added ard $(2-a)\left(L_{\mathrm{F}}\right)$ will equal the number of moles of titratable $\mathrm{If}^{+}$remaining in solution. Thus, $(2-\mathrm{a})\left(\mathrm{L}_{\mathrm{T}}\right)=\left(\mathrm{H}^{+}\right)+(\mathrm{HL})+2\left(\mathrm{H}_{2} \mathrm{~L}\right)-\mathrm{OH}$

Substituting Equations 1 and 2 into Equation 7, yields:

$$
(2-\mathrm{a})\left(\mathrm{L}_{\mathrm{T}}\right)=\left(\mathrm{H}^{+}\right)-(\mathrm{OH})+\frac{(\mathrm{H})(\mathrm{L})}{\mathrm{ka}_{2}}+\frac{2(\mathrm{H})^{2}(\mathrm{~L})}{\mathrm{ka}_{1} \mathrm{ka}_{2}}
$$


Solving Equation 8 for (L) yields:

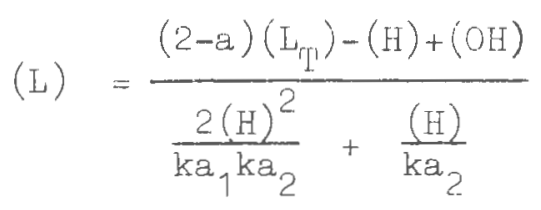

The use of Equation 9 allows the calculation of Iree ligand species present in solution (at a knowts pH after a krown addition of base) during the itratiwt.

Now, let $\bar{n}$ represent the averape nuniter is ligard moltules bound per mole of metal.

Then,

$$
\bar{n}=\frac{M L+2\left(M_{2}\right)}{M_{T}}
$$

Rearranging Equation 5 yields:

$$
(\mathrm{ML})+2\left(\mathrm{ML}_{2}\right)=\mathrm{L}_{\mathrm{T}}-(\mathrm{L})+(\mathrm{HL})+\left(\mathrm{H}_{2} \mathrm{~L}\right)
$$

Substituting Equations 1 and 2 into Equation 11 and dividin. both sides by $\mathrm{M}_{\mathrm{T}}$ yields:

$$
\frac{(\mathrm{ML})+2\left(\mathrm{ML}_{2}\right)}{\mathrm{M}_{\Gamma}}=\frac{\mathrm{L}_{\mathrm{T}^{-}}-\left[1+\frac{(\mathrm{H})}{\mathrm{ka}_{2}}+\frac{(\mathrm{H})^{2}}{\mathrm{ka}_{1} \mathrm{ka}_{2}}\right]\left(\mathrm{I}_{2}\right)}{\mathrm{M}_{\mathrm{T}}}
$$

The left side of Equation 12 is equal to $\bar{n}$.

Therefore,

$$
\overline{n_{1}}=\frac{L_{\mathrm{T}}-\left[1+\frac{(\mathrm{H})}{k a_{2}}+\frac{(\mathrm{H})^{2}}{\mathrm{ka}_{1} \mathrm{ka}_{2}}\right](\mathrm{L})}{\mathrm{M}_{\mathrm{T}}}
$$


It is possible to obtain the values of the consecutive formation constants by plotting $\bar{n}$ versus $-10 g(L) . K_{1}$ is approximately equal to the $-\log$ ( $(L)$ value at $\bar{n}=0.5$ and $K_{2}$ approximately equal to the $-\log (\mathrm{L})$ value at $\bar{n}=1.5$. It should be noted that this method is only valid if the numerical difference between $\mathrm{K}_{1}$ and $\mathrm{K}_{2}$ is large. In the case of a small difference, an iteration procedure is required (see Appendix A).

The problems involved in a study of this type are formidable since the chelation solutions contain an equilibrium mixture of several species, i.e., free ligand, free metal, 1-1 and 2-1 chelate species. It was possible to measure the inhibitory effects caused by free ligand and free cupric ion by using the pure components. However, it was not possible to prepare chelate solutions containing either of the two chelate species in the absence of the other (except in the case of AOH where only a 1-1 species formed). It was necessary, therefore, to design an experiment which would identify the species present in the equilibrium chelate mixtures which was responsible for inhibition. The first step in this approach was to calculate the concentration of individual species present in the equilibrium mixture of ligand and metal under fixed conditions of concentration and $\mathrm{pH}$. The following is a description of these calculations.

In the AOH system, where only a 1-1 chelate species formed, the following expression was derived. The symbols have the same 
meaning as those described in the explanation of Bjerrum's $\overline{\mathrm{n}}$ function.

$$
\begin{aligned}
& \mathrm{M}+\mathrm{L} \quad, \quad \mathrm{K}_{1}=\frac{(\mathrm{ML})}{(\mathrm{M})(\mathrm{L})} \\
& \mathrm{H}_{3} \mathrm{ML} \mathrm{H}_{2} \mathrm{~L}+\mathrm{H}, \mathrm{ka}_{1}=\frac{\left(\mathrm{H}_{2} \mathrm{~L}\right)(\mathrm{H})}{\left(\mathrm{H}_{3} \mathrm{~L}\right)} \\
& \mathrm{H} \mathrm{L}, \mathrm{kg}_{2}=\frac{\left(\mathrm{HL}_{2}\right)(\mathrm{H})}{\left(\mathrm{H}_{2} \mathrm{~L}\right)} \\
& \mathrm{HL}+\mathrm{H}, \mathrm{ka}_{3}=\frac{(\mathrm{L})(\mathrm{H})}{(\mathrm{HL})} \\
& \mathrm{L}_{\mathrm{T}}=\mathrm{H}_{3} \mathrm{~L}+\mathrm{H}_{2} \mathrm{~L}+\mathrm{HL}+\mathrm{L}+\mathrm{ML}
\end{aligned}
$$

Combining Equation 5 with Equations 1 to 4 yields:

$$
\mathrm{I}_{\mathrm{T}}=(\mathrm{L})\left[1+\frac{\mathrm{H}}{\mathrm{kg}_{3}}+\frac{\mathrm{H}^{2}}{\mathrm{ka}_{2} \mathrm{~kg}_{3}}+\frac{\mathrm{H}^{3}}{\mathrm{ka}_{1} \mathrm{ka_{2 }} \mathrm{ka}_{3}}\right]+\mathrm{K}_{1}(\mathrm{M})(\mathrm{L})
$$

And,

$$
M_{T}=M+M L
$$

Setting $\left[1+\frac{H}{k a_{3}}+\frac{H^{2}}{k a_{2} k a_{3}}+\frac{H^{3}}{k a_{1} k a_{2} k a_{3}}\right]$ equal to $\propto$

And combining Equation 6 with Equations 7 and 1 yields:

$$
\mathrm{L}_{\mathrm{T}}=\mathrm{L} \alpha+\frac{\mathrm{K}_{1} \mathrm{IM}_{\mathrm{T}}}{1+\mathrm{K}_{1} \mathrm{~L}}
$$


Rearranging terms to obtain the quadratic form yields:

$$
L^{2}+L\left[\frac{K_{1} M_{T}-K_{1} I_{T}+\alpha}{\alpha K_{1}}\right]-\frac{I_{T}}{K_{1} \alpha}=0
$$

With a knowledge of $\left(\mathrm{M}_{\mathrm{T}}\right),\left(\mathrm{L}_{\mathrm{T}}\right), \mathrm{K}_{1}, \mathrm{ka_{1 }}, \mathrm{ka_{2 }}, \mathrm{ka} a_{3}$, and (H), Equation 6 and 9 could be solved for ( $\mathrm{L}$ ) and (M) with the aid of a computer ${ }^{1}$. The concentration of (ML) could then be obtained from Equation 7 and $\mathrm{K}_{1}$ solved from Equation 1.

In the AH and HP systems, the calculations were further complicated because of the presence of a 2-1 chelate. The following expression was derived following the original method outlined by Bolton (34).

$$
\begin{aligned}
& \mathrm{M}+\mathrm{I} \rightleftharpoons \mathrm{ML} \quad, \quad \mathrm{K}_{1}=\frac{(\mathrm{ML})}{(\mathrm{M})(\mathrm{L})} \\
& \mathrm{ML}+\mathrm{I} \rightleftharpoons \mathrm{ML}_{2} \quad, \quad \mathrm{~K}_{2}=\frac{\left(\mathrm{ML}_{2}\right)}{(\mathrm{ML})(\mathrm{I})} \\
& \mathrm{H}_{2} \mathrm{~L}=\mathrm{HL}+\mathrm{H} \quad, \quad \mathrm{ka}_{1}=\frac{(\mathrm{HL})(\mathrm{H})}{\left(\mathrm{H}_{2} \mathrm{I}\right)} \\
& \mathrm{HL} \rightleftharpoons \mathrm{H}+\mathrm{I} \quad \mathrm{ka}_{2}=\frac{(\mathrm{H})(\mathrm{L})}{(\mathrm{HL})} \\
& \mathrm{L}_{\mathrm{T}}=\mathrm{H}_{2} \mathrm{~L}+\mathrm{HL}+\mathrm{L}+\mathrm{ML}+2 \mathrm{ML}_{2}
\end{aligned}
$$

${ }^{1}$ IBM 1410; Fortran IV Language. 
Combining Equation 5 with Equations 1 to 4 yields:

$$
\mathrm{I}_{\mathrm{T}}=(\mathrm{L})\left[1+\frac{\mathrm{H}}{\mathrm{ka_{2 }}}+\frac{\frac{2}{\mathrm{H}^{2}}}{\mathrm{ka}_{1} \mathrm{ka}_{2}}\right]+\mathrm{K}_{1}(\mathrm{M})(\mathrm{L})+2 \mathrm{~K}_{1} \mathrm{~K}_{2}(\mathrm{M})(\mathrm{L})^{2}
$$

And,

$$
\begin{gathered}
M_{T}=M+M L+M L_{2} \\
\text { Setting }\left[1+\frac{H}{\mathrm{ka}_{2}}+\frac{H^{2}}{\mathrm{ka}_{1} \mathrm{ka}_{2}}\right] \text { equal to } \propto
\end{gathered}
$$

And combining Equation 6 with Equations 1,2, and 7 yields:

$$
I_{T}=L \propto+\frac{K_{1} I M_{T}}{1+K_{1} I+K_{1} K_{2} L^{2}}+\frac{2 K_{1} K_{2} L^{2} M_{T}}{1+K_{1} L+K_{1} K_{2} L^{2}}
$$

Rearranging to obtain the cubic form yields:

$$
\mathrm{L}^{3}+\mathrm{L}^{2} \quad\left[\frac{\alpha+2 \mathrm{~K}_{2} \mathrm{M}_{\mathrm{T}}-\mathrm{K}_{2} \mathrm{I}_{\mathrm{T}}}{\mathrm{K}_{2} \alpha}\right]+\mathrm{L}\left[\frac{\alpha+\mathrm{K}_{1} \mathrm{M}_{\mathrm{T}}-\mathrm{K}_{1} \mathrm{I}_{\mathrm{T}}}{\mathrm{K}_{1} \mathrm{~K}_{2} \alpha}\right]-\frac{\mathrm{I}_{\mathrm{T}}}{\mathrm{K}_{1} \mathrm{~K}_{2} \alpha}=0
$$

With a knowledge of $\left(\mathrm{M}_{T}\right),\left(\mathrm{I}_{\mathrm{T}}\right), \mathrm{K}_{1}, \mathrm{~K}_{2}, \mathrm{k} \mathrm{a}_{1}, \mathrm{ka} \mathrm{a}_{2}$, and (H), Equations 6 and 9 could be solved for (L) and (M) by a method of approximations. The computer programs used for the solution of these expressions are shown in the Appendix, (see Appendix $B$ and $C$ ). 


\section{RESULTS AND DISCUSSION}

\section{Free Cupric Ion Determinatiors}

In the polarographic studies, a calibration curve of ditfusion current $\left(i_{D}\right)$ versus cupric ion was prepared (Figure 1). It was anticipated that very small concentrations of $\mathrm{Cu}^{++}$could be detected by extrapolating the calibraticn curve tu very low $\mathrm{Cu}^{++}$values. Unfortunately, the total concentration of $\mathrm{Cu}^{++}$

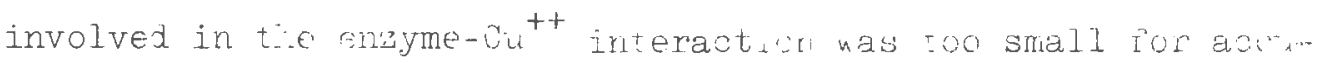
rate measurement by this method. Repea+ed efforts to detect

these small $\mathrm{Cu}^{++}$concentrations were urisuccessful.

The colorimetric method for cupxic ion determinations (see Experimental) also presented problems. It was found that although a suitable calibration curve could be made by plottirs, absorption versus concertration at relatively high concentrations of metal (Figure 2), attempts to analytically reproduce the minute quantities of $\mathrm{Cu}^{++}$apparertly associatert with enzyme binding were unsuccessful. Several modificatiuns of the litentture procedure were tried including dialysis of large volumes and subsequent evaporation techniques to increase the per cent concentration of $\mathrm{Cu}^{++}$. The major difficulty encountered was color fading. The colored complex formed vetween tile emplexint agent and $\mathrm{Cu}^{++}$was found to be relatively unstable. Attemptis were made to carry out the complexation directly in the spectr.... photometer cuvette, but the results obtained using this technigite proved to be unreprodicible. 


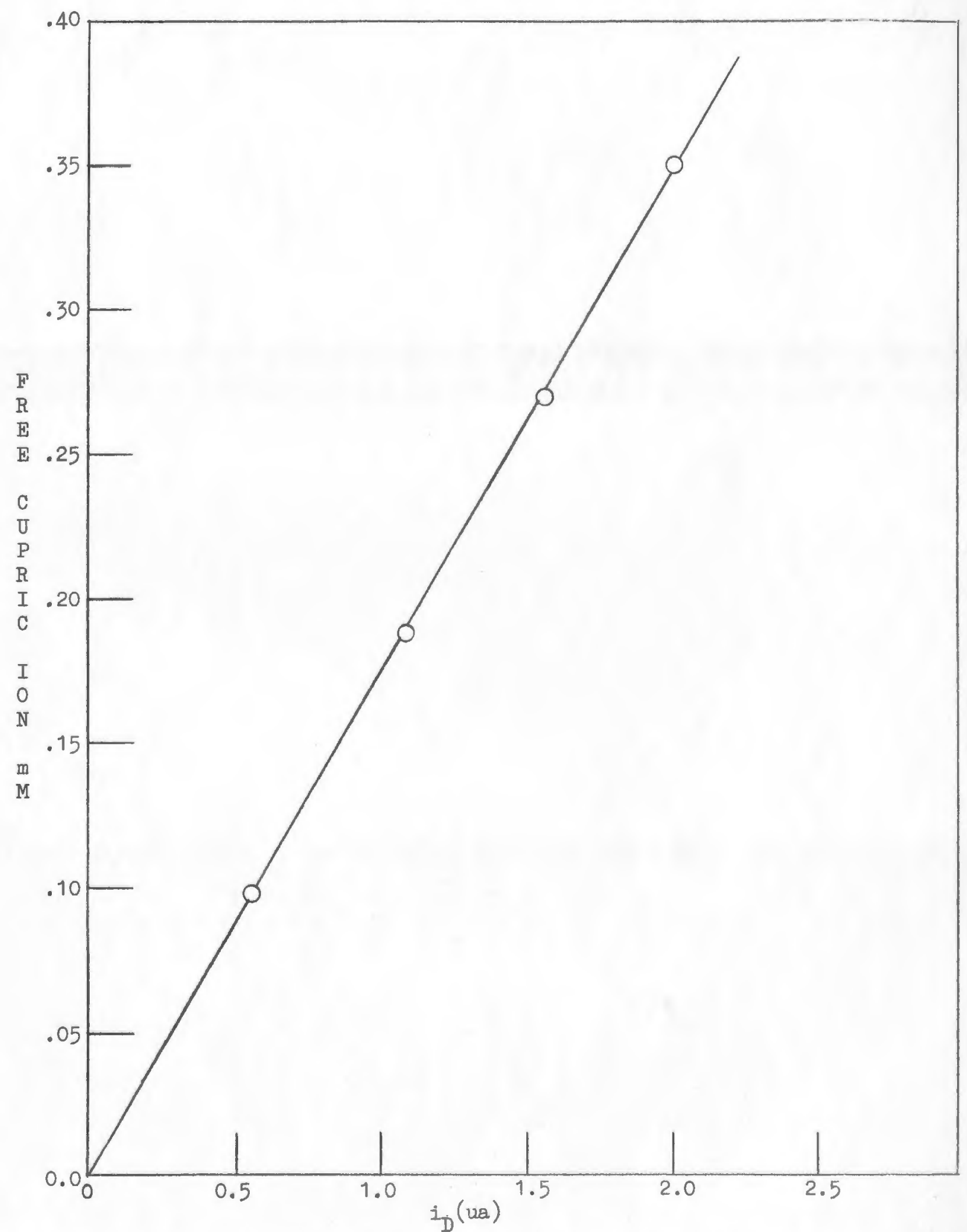

Figure 1. Calibration curve for free cupric ion versus diffusion current ( $i_{D}$ ) 


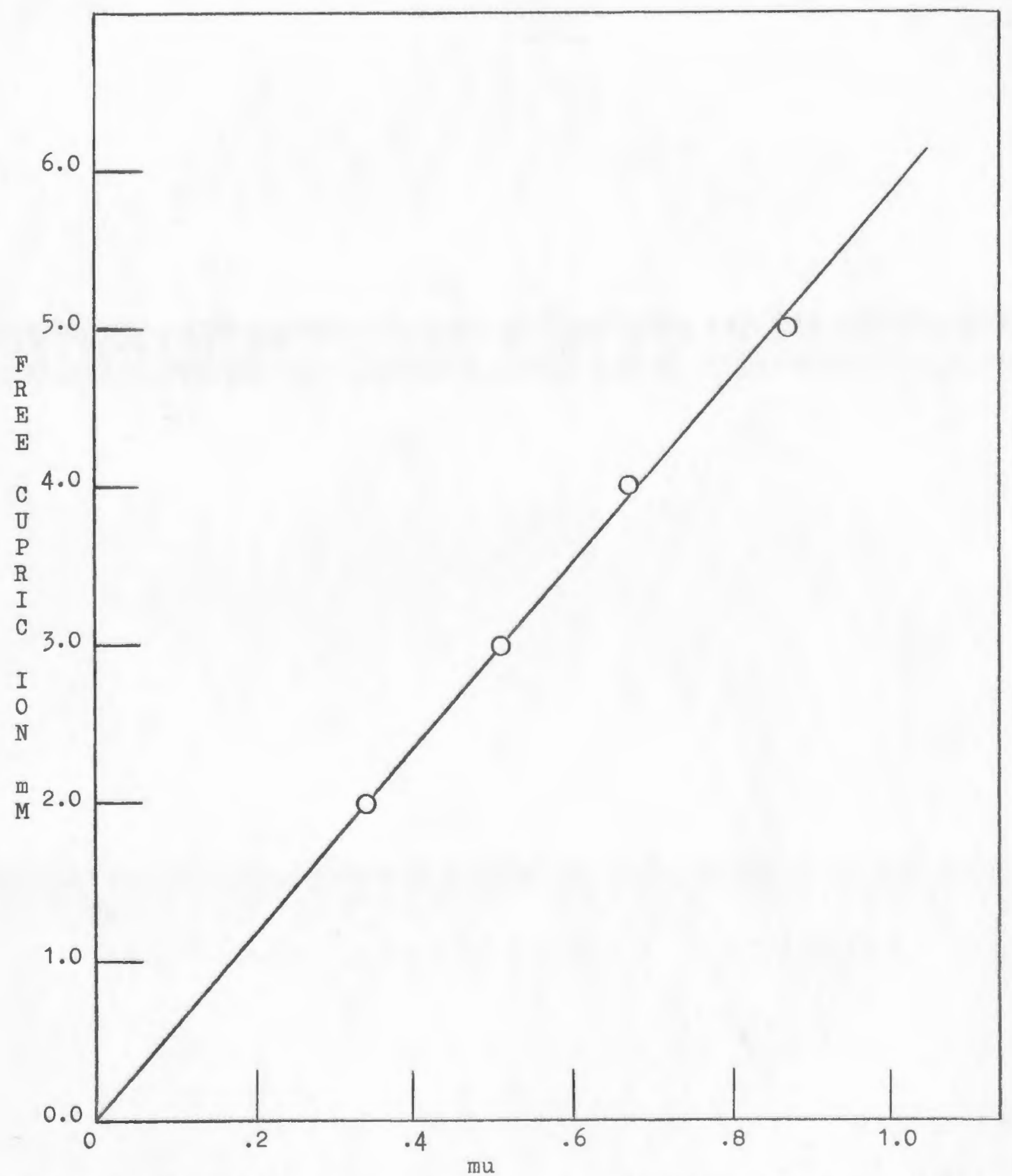

Figure 2. Calibration curve for free cupric ion versus absorbance (mu). 
Although the results of these studies were iroorclusive, certain observations of interest were noted. It appeared that the amount of cupric ion bound to the erzyme or capable of birding was extremely small. Although the actual quantities of metal ion involved were not determined, they were fourd to be less than $1 \times 10^{-6} \mathrm{M}$. Further, wher relatively large amounts of cupric ion were added to the enzyme and the mixture dialysed, analyses for $\mathrm{Cu}^{++}$were nut reproducible. linis lak or rep?ducibility could have been due to metal adsibance on the di.alysing membrane, but attempts to decermine the actual concentration of $\mathrm{Cu}^{++}$capable of adsorbing on the membrane were ursuccessful.

\section{Ligand Dissociation Constants}

The dissociation corstants for all three limands determined by potentiometric titrations with standard base are shrw' in Table I. Literature values are irdicated wher available. Differences between the literature values and expirimental values may be attributed to differences in ionic strength and the temperature at which the determinations were made. With the exception of $\mathrm{AOH}$ (soe bolow), the acid diswnia.

tions were determined from the pH at the mid-points in the titration curves for each ligand.

\section{Stability Constants}

A summary of the chelate stabiluty constants to all three ligands appears in Table II. I.iterature values are ju 
TABLE I

LIGAND DISSOCIATION CONSTANTS

\begin{tabular}{lcccccc}
\hline \hline Ligand & ${ }^{\mathrm{pKa}}{ }_{1}$ & $\mathrm{pKa}_{2}$ & $\mathrm{pKa}_{3}$ & $\begin{array}{c}\text { Ionic } \\
\text { Strength }\end{array}$ & $\begin{array}{c}\text { Temp. } \\
{ }^{\circ} \mathrm{C}\end{array}$ & Reference \\
$\mathrm{AOH}$ & 8.01 & 9.58 & 14.20 & 0.162 & 30 & $\ldots$ \\
$\mathrm{AH}$ & 8.50 & 10.24 & $\ldots$ & 0.162 & 30 & $\ldots$ \\
$\mathrm{HP}$ & 2.20 & 9.36 & $\ldots$ & 0.162 & 30 & $\ldots$ \\
& & & & & & $\ldots$ \\
$\mathrm{AOH}$ & 8.23 & 9.68 & $\ldots$ & 0.100 & 20 & 39 \\
$\mathrm{AH}$ & 8.88 & 10.64 & $\ldots$ & 0.100 & 20 & 46 \\
$\mathrm{HP}$ & 1.92 & 9.73 & $\ldots$ & 0.100 & 20 & 47 \\
& & & & & & \\
\hline
\end{tabular}




\section{TABLE II}

STABILITY CONSTANTS FOR LIGAND INTERACTIONS WITH $\mathrm{Cu}^{++}$

\begin{tabular}{|c|c|c|c|c|c|}
\hline Ligand & $\log \mathrm{K}_{1}$ & $\log \mathrm{K}_{2}$ & $\begin{array}{c}\text { Ionic } \\
\text { Strength }\end{array}$ & $\begin{array}{c}\text { Temp. } \\
{ }^{\circ} \mathrm{C}\end{array}$ & Ref. \\
\hline $\mathrm{AOH}$ & 18.40 & ... & 0.162 & 30 & $\ldots$ \\
\hline $\mathrm{AH}$ & 9.29 & 6.96 & 0.162 & 30 & $\ldots$ \\
\hline HP & 8.88 & $7 \cdot 21$ & 0.162 & 30 & $\ldots$ \\
\hline \multicolumn{6}{|c|}{ Literature Values } \\
\hline $\mathrm{AOH}$ & $\cdots$ & $\cdots$ & $\cdots$ & $\cdots$ & $\cdots$ \\
\hline $\mathrm{AH}$ & 9.62 & 7.00 & 1.000 & 30 & 53 \\
\hline $\mathrm{HP}$ & ... & ... & ... & .. & $\ldots$ \\
\hline
\end{tabular}


dicated when available. In general, the formation constants for all three ligand-metal interactions were determined by titrating several ligand-metal ratios with standard base. Because each ligand exhibited different chelating properties, their interactions with $\mathrm{Cu}^{++}$will be discussed separately.

$\underline{\mathrm{AOH}}$. Titrations of $\mathrm{Cu}^{++}-\mathrm{AOH}(\mathrm{HCl})_{2}$ mixtures as well as free amine di-HCl are shown in Figure 3. $\mathrm{AOH}-\mathrm{Cu}^{++}$ratios of 1-1 and greater, all yielded exactly three equivalents of $\mathrm{H}^{+}$ per metal ion (Figure 4). This could only be explained on the basis of formation of a 1-1 terdentate chelate with simultaneous release of the ethanolic proton. That a 2-1 chelate did not form was evident from a comparison of curves $A, B$ and $C$ in Figure 3; curve $\mathrm{C}$ was found to be a summation of curves $\mathrm{A}$ and B. Since a 2-1 chelate did not form, the possibility that the third proton came from $\mathrm{Cu}^{++}$-bound water was excluded.

The system was also analysed according to the method of Job (48), utilizing the peak at $623 \mathrm{mu}$ exhibited by the $\mathrm{Cu}^{++}$ chelate. Unfortunately, mixtures containing a mole fraction of amine less than 0.5 precipitated at the $\mathrm{pH}$ of the experiment. Therefore, no maximum could be observed in a 1-1 ratio system, but solutions containing larger ratios of amine (at constant total concentration) showed decreasing absorption which is corroborative evidence of only 1-1 chelate formation. 


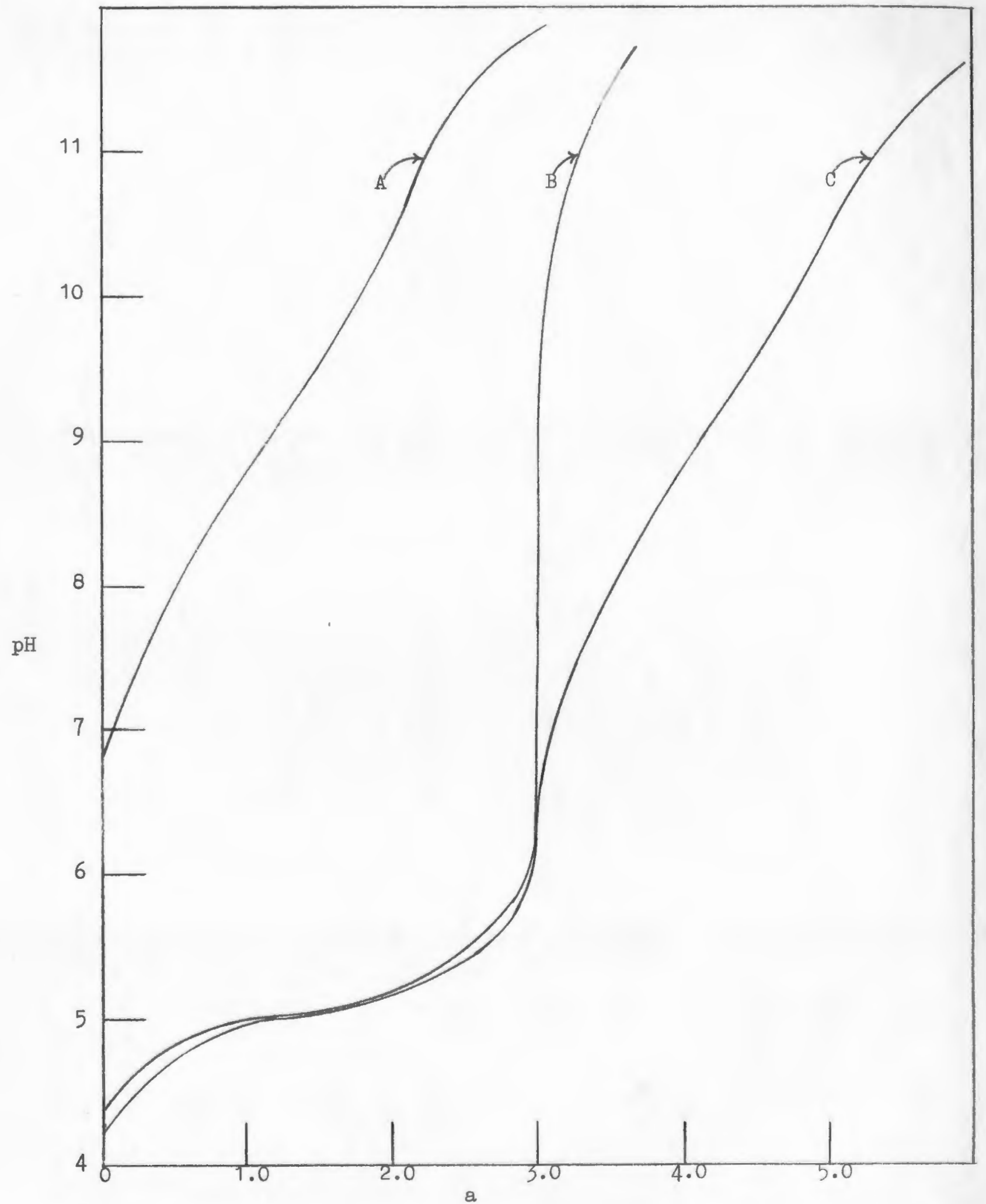

Figure 3. Titration of 1,3 diaminopropanol-2(diHCl) in the absence of, and in the presence of, $\mathrm{Cu}^{++}$. A, titration of $1 \times 10^{-2} \mathrm{M} \mathrm{AOH}$ with $\mathrm{NaOH}$; $\mathrm{B}$, equimolar amounts of $\mathrm{Cu}^{++}$and $\mathrm{AOH} ; \mathrm{C}, 100$ per cent excess of AOH; a denotes moles of base added per mole of $\mathrm{AOH}$. 


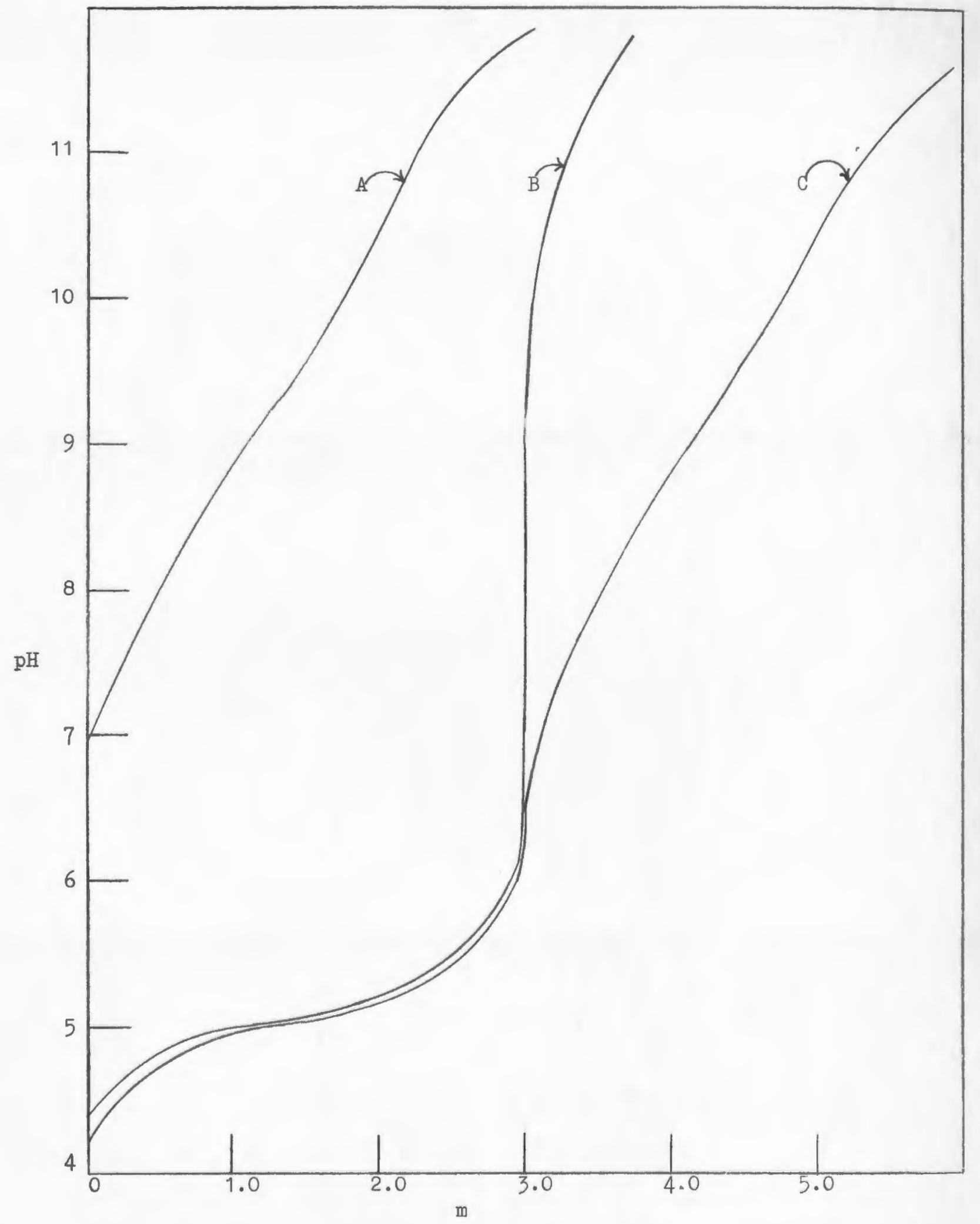

Figure 4. Titration of 1,3 diaminopropanol-2(diHCl) in the absence of, and in the presence of, $\mathrm{Cu}^{++}$. A, titration of $1 \times 10^{-2} \mathrm{M} \mathrm{AOH}$ with $\mathrm{NaOH}$; $\mathrm{B}$, equimolar amounts of $\mathrm{Cu}^{++}$and $\mathrm{AOH} ; \mathrm{C}, 100$ per cent excess of $\mathrm{AOH}$; $m$ denotes moles of base added per mole of metal. 
Since the ethanolic hydrogen was released during the chelation of $\mathrm{AOH}$ and $\mathrm{Cu}^{++}$, evaluatiur of the stability constant for this 1-1 species required the evaluation of the ka of this ethanolic group. It seemed reasonable to believe that this ka value could be determined spectrophotometrically. Ideally: two distinct peaks corresponding to the dissociated and undissociated species would appear.

$$
\text { Triforturately, the necessity of us nger systems of very }
$$
high pH introduced solvert effects why prevented elear-ant. resolution of the peaks. Instead one peak appeared which, witinually shifted toward higher wavelengths with a correspr.liding lowering of absorption as the $\mathrm{pH}$ was increased. Then at plI 14.06 the absorption began to increase while the peak continued to shift as before. This increase in absorption was attributed to $(-0)^{-}$formation and the $\mathrm{pH}$ of the solution when this was first observed was considered to be the $\mathrm{pK}_{\mathrm{a}}$ of the ethanolic hydrogen.

Admittedly, the method was only an appruximation and some corroborative evidence was needed. A theoretical calculation of the $\mathrm{pk}_{\mathrm{a}}$ of the ethanolic hydrogen was made using: the method of inductive effects outlined by Hine (49). For a series of substituted acetic acids (5o), $\gamma$, the measure of electron donation or acceptance, was +3.651 . When this value was used in the expression derıved fur substituted alcohols and currections were made for carbon chain length: 
and the presence of two positively charged nitrogens (51), the $\mathrm{pK}_{\mathrm{a}}$ was calculated to be 14.35. The estimated $\mathrm{pK}_{\mathrm{a}}$ value of 14.06 found in the spectrophotometric method appears, therefore, to be of the correct order of magnitude.

Our calculation of the stability constant for the (CuAO) ${ }^{+}$ chelate $\left(\mathrm{K}_{1}\right)$ agreed well with the $\log \mathrm{K}_{\mathrm{s}}$ value of $3.57 \pm 0.17$ obtained by Bertsch, Fernelius, and Block $(52,53)$, if the following relationships are considered:

$$
\mathrm{Cu}^{++}+\mathrm{AOH} \rightleftharpoons \mathrm{CuAO}^{+}+\mathrm{H}^{+}
$$

Then,

$$
\mathrm{K}_{\mathrm{B}}=\frac{(\mathrm{CuAO}+)\left(\mathrm{H}^{+}\right)}{\left(\mathrm{Cu}^{++}\right)(\mathrm{AOH})}
$$

but

$$
\mathrm{K}_{1}=\frac{\left(\mathrm{CuAO}^{+}\right)}{\left(\mathrm{Cu}^{++}\right)\left(\mathrm{AO}^{-}\right)}
$$

And, because

$$
\mathrm{ka}_{3}=\frac{\left(\mathrm{H}^{+}\right)\left(\mathrm{AO}^{-}\right)}{(\mathrm{AOH})}
$$

then,

$$
\mathrm{K}_{1}=\frac{\mathrm{k}_{\mathrm{s}}}{\mathrm{ka}_{3}}
$$

the value of $\mathrm{K}_{1}$ is depencent on the ka. Using our estimated ka we found an average value of $2.5 \times 10^{18}$ for $\mathrm{K}_{1}$.

AH. Preliminary examination of the titration curves of several ligand-metal ratios of $\mathrm{AH}$ and $\mathrm{M}^{++}$indicated the for- 
mation of both a stable 1-1 and a stable 2-1 chelate (Figure 5).

As can be seen, in Figure 6, four protons were titrated per mole of metal corresponding to 2-1 chelate formation. The numerical values for the two successive stability constants $\left(\mathrm{K}_{1}\right.$ and $\left.\mathrm{K}_{2}\right)$ were calculated using the $\bar{n}$ relationship derived earlier in this thesis. Table III contains the results of calculated free ligand species at various $\bar{n}$ values. Since the $\mathrm{K}_{1}$ and $\mathrm{K}_{2}$ constants exhibited a large numerical difference, the log values of free ligand species at $\bar{n}=0.5$ and 1.5 were taken as the actual values of $\mathrm{K}_{1}$ and $\mathrm{K}_{2}$ respectively.

프. Potentiometric titrations of the ligand salt and 2-1 $\mathrm{HP}-\mathrm{M}^{++}$mixtures with standard base are shown in Figure 7 . Titration curves of ratios greater than 2-1, indicated no higher chelates and preliminary examination of these curves indicated the formation of a 1-1 chelate and a relatively stable 2-1 chelate. Further, the absence of a strong inflection corresponding to 1-1 formation appeared to indicate a close proximity between the stability constants for the 1-1 and 2-1 chelate species. Further evidence supporting 2-1 formation was noted when $\mathrm{pH}$ was plotted versus moles of base per mole of metal in Figure 8. The end-point occurred when two protons were titrated per mole of metal ion indicating the attachment of two ligand molecules per metal ion. Calculations of free ligand species at various $\bar{n}$ values is shown in Table IV and preliminary eval- 


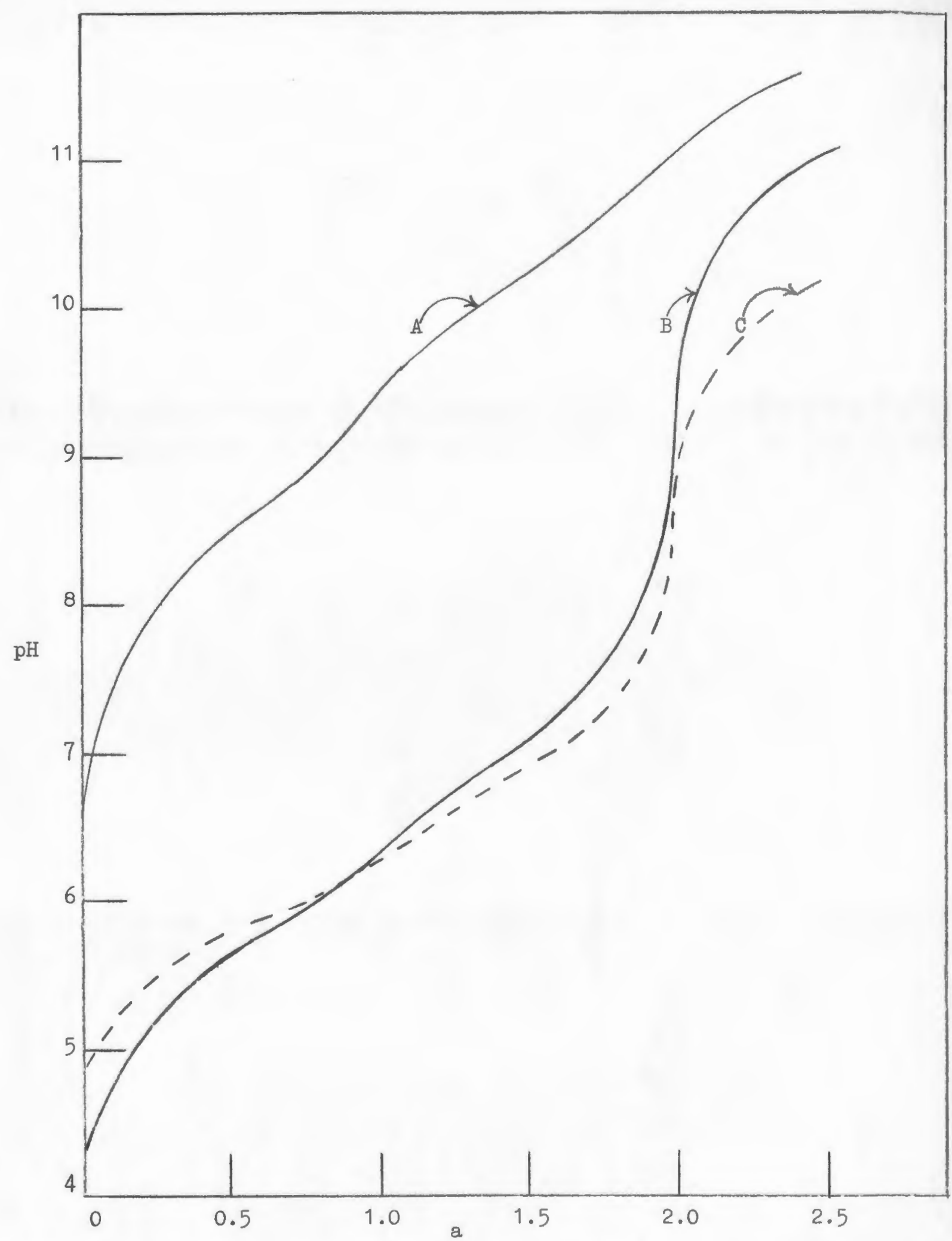

Figure 5. Titration of 1,3 diaminopropane(diHCl) in the absence of, and in the presence of, $\mathrm{Cu}^{++}$ion. A, titration of $1 \times 10^{-2} \mathrm{M} \mathrm{AH}$ with $\mathrm{NaOH} ; \mathrm{B}$, ligand-metal ratio of $2-1$; $\mathrm{C}$, ligand-metal ratio of 3-1; a denotes moles of base added per mole of $\mathrm{AH}$. 


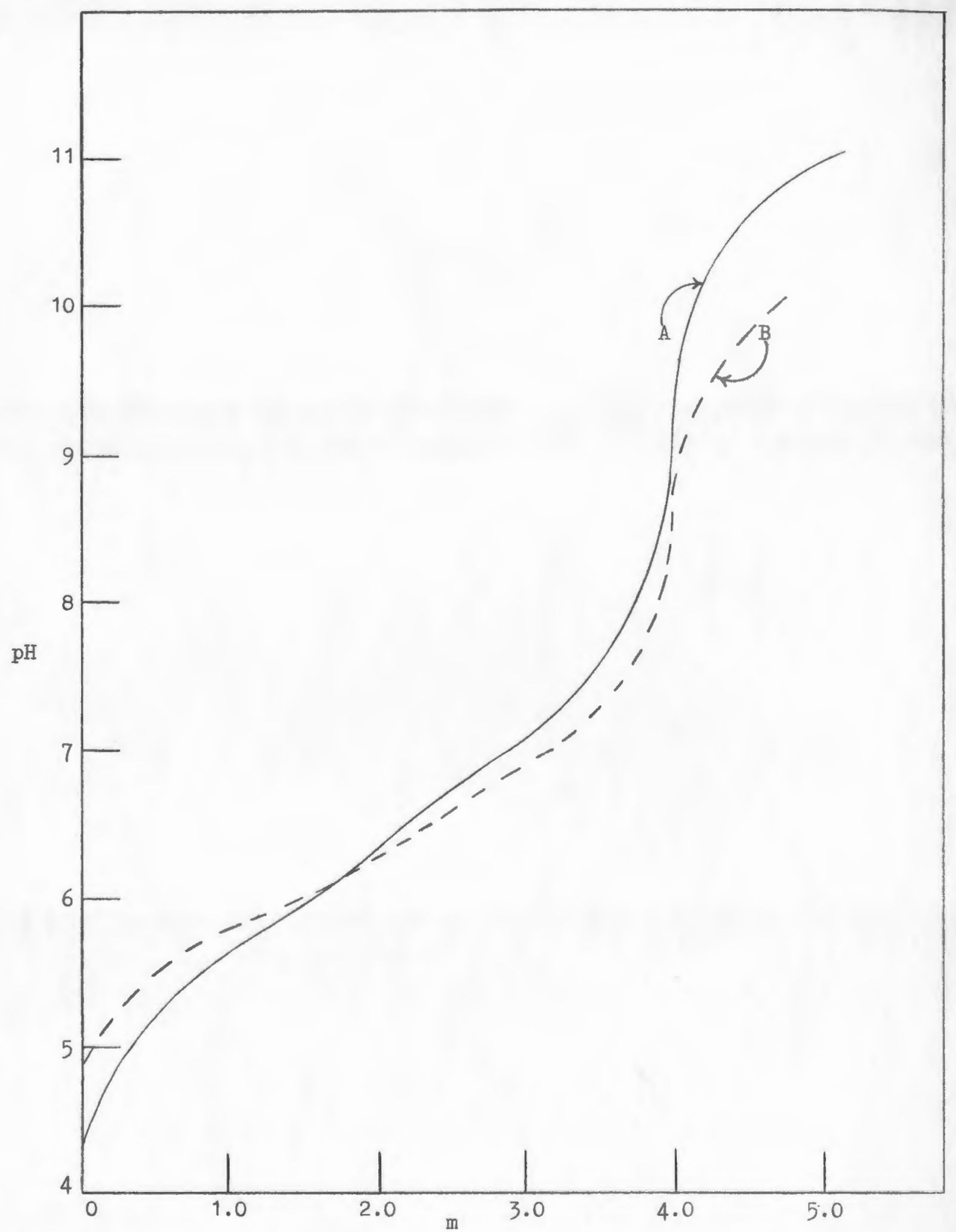

Figure 6. Titration of 1,3 diaminopropane (diHCl) in the presence of $\mathrm{Cu}^{++}$ion. A, ligand-metal ratio of 2-1; B, ligand-metal ratio of $3-1 ; m$ denotes moles of base added per mole of metal. 
TABLE III

CALCULATED FREE LIGAND SPLCIES AT VARIUJS $\bar{n}$ VALUES FOR THE AI-C INTERACTION $^{++}$

\begin{tabular}{|c|c|c|c|}
\hline $\mathrm{pH}$ & $\left(\mathrm{I}^{-}\right)$ & $\because$ & $-1 \mathrm{ge} \quad(.1)$ \\
\hline 5.39 & $1.85 \times 10^{-10}$ & $C .250$ & 9.73 \\
\hline 5.55 & $3.70 \times 10^{-10}$ & 0.402 & 9.45 \\
\hline 5.66 & $5.18 \times 10^{-10}$ & 0.500 & 9.23 \\
\hline 5.81 & $9.17 \times 10^{-10}$ & 0.650 & 9.04 \\
\hline 6.75 & $3.62 \times 10^{-8}$ & 1.250 & $7 \cdot 44$ \\
\hline 6.88 & $5.54 \times 10^{-8}$ & 1.360 & 7.26 \\
\hline 7.08 & $1.08 \times 10^{-7}$ & 1.472 & 6.97 \\
\hline 7.33 & $2.28 \times 10^{-7}$ & 1.640 & 6.62 \\
\hline
\end{tabular}




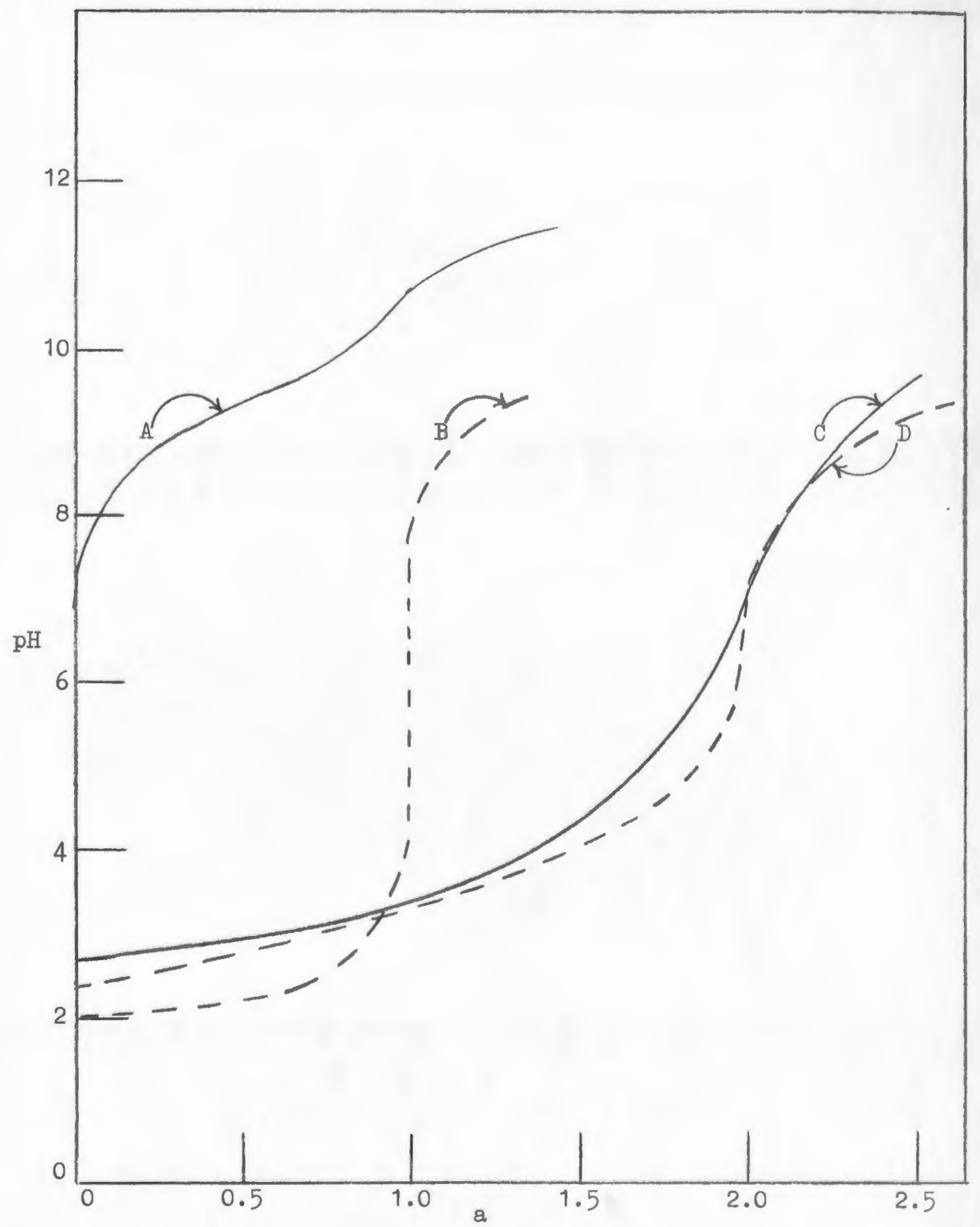

Figure 7. Titration of hydroxy-L-proline(HCl) in the absence of, and in the presence of $\mathrm{Cu}^{++}$ion. A, titration of $1 \times 10^{-2} \mathrm{M}$ free amine with $\mathrm{NaOH} ; \mathrm{B}$, titration of $1 \times 10^{-2} \mathrm{M}$ mono-HCl salt with $\mathrm{NaOH} ; \mathrm{C}$, ligand-metal ratio of 2-1; $D$, ligand-metal ratio $3-1$; a denotes moles of base added per mole of HP. 


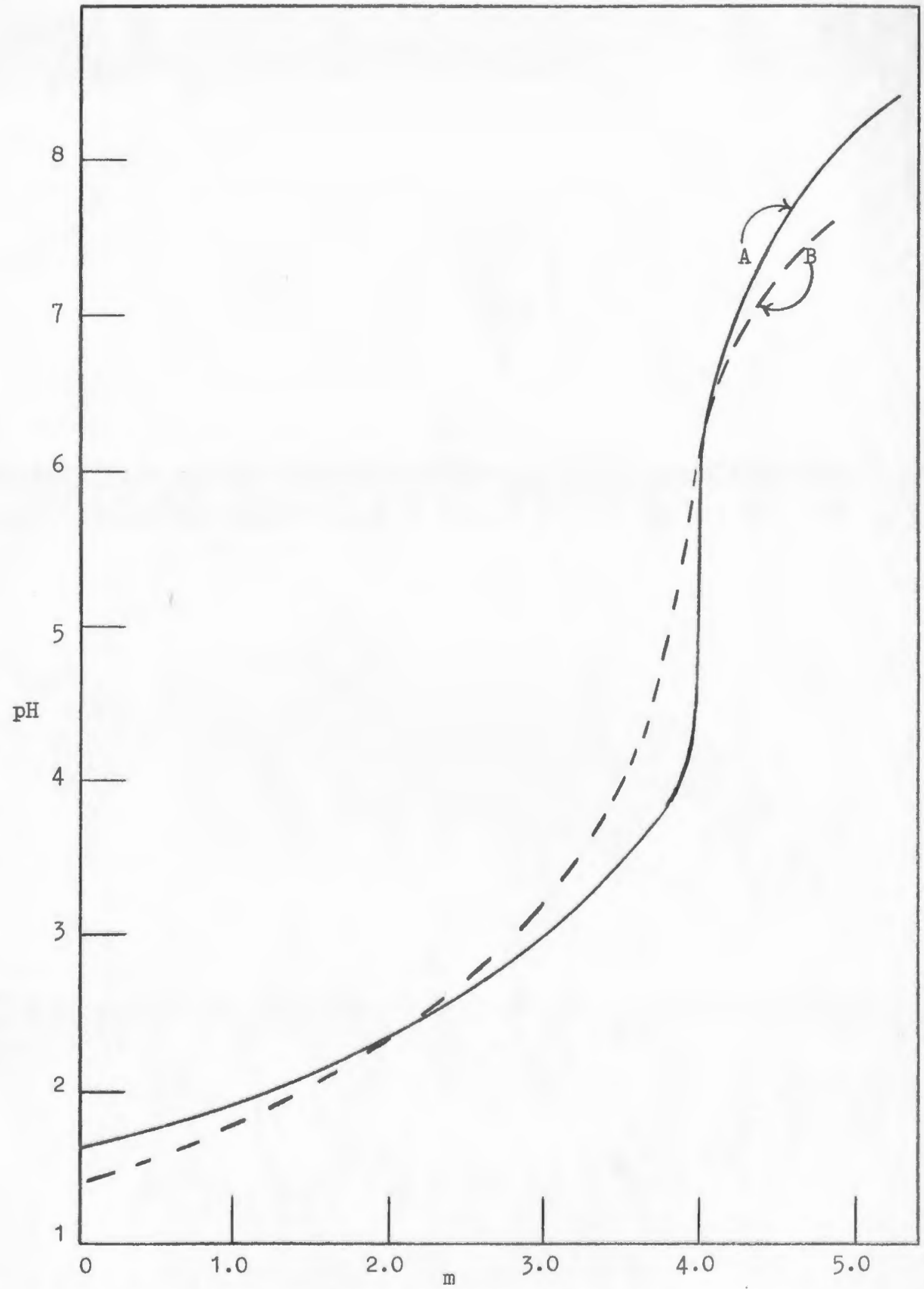

Figure 8. Titration of hydroxy-L-proline(HCl) in the presence of Cutt ion. A, ligand-metal ratio of 2-1; B, ligand-metal ratio of $3-1$; m denotes moles of base added per mole of metal. 
TABLE IV

CALCULATED FREE LIGAND SPECIES AT VARIOUS $\bar{n}$ VALUES FOR THE HP-Cu ${ }^{++}$INTERACTION

\begin{tabular}{cccc}
\hline $\mathrm{pH}$ & $\left(\mathrm{L}^{-}\right)$ & $\overline{\mathrm{n}}$ & $-\log (\mathrm{L})$ \\
\hline 2.04 & $6.67 \times 10^{-10}$ & 0.303 & 9.18 \\
2.12 & $8.31 \times 10^{-10}$ & 0.383 & 9.08 \\
2.21 & $1.07 \times 10^{-9}$ & 0.461 & 8.97 \\
2.31 & $1.39 \times 10^{-9}$ & 0.539 & 8.86 \\
3.36 & $1.51 \times 10^{-8}$ & 1.061 & 7.82 \\
3.88 & $3.72 \times 10^{-8}$ & 1.314 & 7.43 \\
4.28 & $6.75 \times 10^{-8}$ & 1.504 & 7.17 \\
4.52 & $9.37 \times 10^{-8}$ & 1.602 & 7.03 \\
\hline
\end{tabular}


uation of $K_{1}$ and $K_{2}$ at $\bar{n}=0.5$ and 1.5, respectively, indicated a small numerical difference between the two successive formation constants. In order to obtain more accurate values for $\mathrm{K}_{1}$ and $\mathrm{K}_{2}$, it was necessary to use the iteration procedure referred to in the introduction of this thesis. A brief description of this procedure, using actual values necessary for the evaluation of $\mathrm{K}_{1}$ and $\mathrm{K}_{2}$ for the interaction of $\mathrm{HP}_{-} \mathrm{Cu}^{++}$, is shown in the Appendix. Figure 9 shows the results of plotting $\bar{n}$ versus the negative log of free ligand concentration (pL) for the $\mathrm{AH}$ and $\mathrm{HP}$ syrtems.

Inhibition Studies

As was mentioned earlier, the chelate solutions contained an equilibrium mixture of several species. The questions to be resolved were which species acted as inhibitors and how did they exert their inhibition. In the case of the $\mathrm{AOH}$ ligand, free ligand, free metal and/or 1-1 chelate could be responsible for inhibition. With the $\mathrm{AH}$ and HP compounds, the additional possibility of inhibition by the 2-1 chelate species was also considered.

Inhibition by Free Cupric Ion. The influence of free cupric ion on the hydrolysis of acetylcholine by acetylcholinesterase, has been reported by Bolton (34). The results of this study indicated that concentrations of free cupric ion below $2 \times 10^{-5} \mathrm{M}$ did not exert a significant inhibitory action 


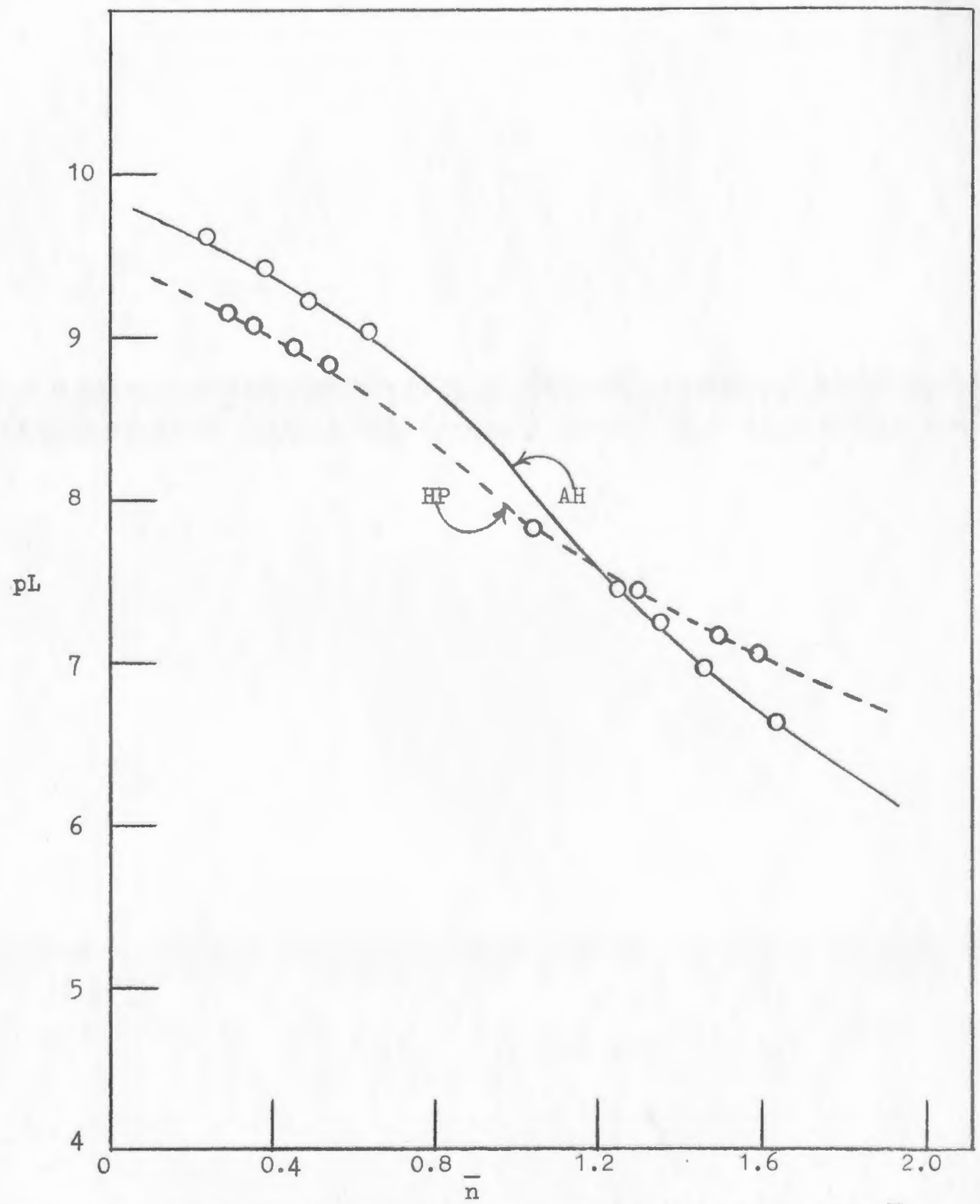

Figure 9. Formation functions of copper chelates of $\mathrm{AH}$ and $\mathrm{HP} ; \overline{\mathrm{n}}=$ average number of ligands bound per mole of metal ion; $\mathrm{pL}=$ negative logarithm of $\mathrm{I}$. 
on the acetylcholinesterase system, although this value was somewhat dependent on the concentration of enzyme. Further, it was found that inhibition by free cupric ion was usually accompanied by a time dependence. When the concentration of free cupric ion was relatively large, the measured velocity of the inhibited enzyme-substrate reaction changed as a function of time, whereas, when the concentration of free cupric ion was relatively small, the observed velocity remained constant for periods of time up to one hour. Because of this possible interference from cupric ion, all chelate solutions used contained less than $1 \times 10^{-6} \mathrm{M}$ free cupric ion at the experimental $\mathrm{pH}$ values used in this thesis. The concentration of cupric ion was controlled by a careful choice of the $\mathrm{pH}$, the concentration of chelate solution, and the ratio of ligand to metal. The individual effects of these three experimental conditions will be discussed separately for each ligand. As a further check for possible $\mathrm{Cu}^{++}$interference, time dependence studies were performed initially on all systems. Whenever cupric ion interference was suspected, the data could not be analysed and has been omitted.

Inhibition by Free Ligand. The contribution of free ligand to the inhibition of the acetylcholinesterase system was examined by Bolton $(34,36)$. Results showed that within the concentrations used in these experiments, free ligand exhibited no inhibitory 
effects. Studies run with $\mathrm{AOH}, \mathrm{AH}$, ard $\mathrm{HP}$ also showed that these ligand molecules exhibited $\gamma_{1}$; intibitory properties ever when concentrations of total ligand used were far in excess of the concentrations normally encountered in our inhibition studies.

Inhibition by the AOH System. The resilts of enzyme inhibition by a 2.1-1 lisara-metal ratio solution af $\mathrm{AOH}-\mathrm{Cu}{ }^{++}$ at several $\mathrm{pH}$ values, are shown in Table $\mathrm{V}$. The chuice of lypardmetal ratio was not criticil with thlas bystem lecaus tue turmation constart resulting from the terdentwte a tachme 1, was very large. Because of the very large 1-1 formation constant, the concentration of free cupric ion was very low over a $\mathrm{pH}$ range from 7.5 to 9.0. The kinetic data obtained for this system was found to be independent of time. Examination of Figure 4 shows a large $\mathrm{pH}$ change at the end-point of the tithation, corresponding to 1-1 chelate formation. Aralysis of the equilibrium chelate solution at pH values from 7.5 to 9.0 usire the computer approximation method described in the Apperidix: revealed no change in the cuncentration of 1-1 chelate species throughout the $\mathrm{pH}$ range used. Also, when the ligand-metal ratio was changed to $2.2-1$ and the equilibrium chelate solution analysed, it was found that the concentiation of cupric ion was lowered, but the concentration of 1-1 species did nut change. 


\section{TABLE V}

INHIBITION BY 1-1 AOH CHELATES IN A 2.1-1 LIGAND-METAL RATIO SOLUTION

\begin{tabular}{|c|c|c|c|c|}
\hline $\mathrm{pH}$ & $\begin{array}{l}\text { Molar } \\
\text { Conc. } \\
\text { Chelate } \\
\times 10^{-3}\end{array}$ & $\begin{array}{l}\text { Molar } \\
\text { Conc. 1-1 } \\
\text { Chelate } \\
\times 10^{-3}\end{array}$ & $\begin{array}{l}\text { Molar } \\
\text { Conc. } \\
\text { Free } \mathrm{Cu}^{++} \\
\times 10^{-10}\end{array}$ & Vo/T \\
\hline 7.5 & $\begin{array}{l}1 \\
2 \\
3 \\
4\end{array}$ & $\begin{array}{l}0.9 \\
1.9 \\
2.9 \\
3.9\end{array}$ & $\begin{array}{l}9.3 \\
9.3 \\
9.3 \\
9.3\end{array}$ & $\begin{array}{l}1.074 \\
1.091 \\
1.104 \\
1.111\end{array}$ \\
\hline 8.0 & $\begin{array}{l}1 \\
2 \\
3 \\
4\end{array}$ & $\begin{array}{l}0.9 \\
1.9 \\
2.9 \\
3.9\end{array}$ & $\begin{array}{l}0.45 \\
0.45 \\
0.45 \\
0.45\end{array}$ & $\begin{array}{l}1.021 \\
1.048 \\
1.072 \\
1.096\end{array}$ \\
\hline 8.25 & $\begin{array}{l}1 \\
2 \\
3 \\
4\end{array}$ & $\begin{array}{l}0.9 \\
1.9 \\
2.9 \\
3.9\end{array}$ & $\begin{array}{l}0.11 \\
0.11 \\
0.11 \\
0.11\end{array}$ & $\begin{array}{l}1.020 \\
1.037 \\
1.058 \\
1.080\end{array}$ \\
\hline 8.50 & $\begin{array}{l}1 \\
2 \\
3 \\
4\end{array}$ & $\begin{array}{l}0.9 \\
1.9 \\
2.9 \\
3.9\end{array}$ & $\begin{array}{l}0.031 \\
0.031 \\
0.031 \\
0.031\end{array}$ & $\begin{array}{l}1.016 \\
1.034 \\
1.057 \\
1.070\end{array}$ \\
\hline 8.75 & $\begin{array}{l}1 \\
2 \\
3 \\
4\end{array}$ & $\begin{array}{l}0.9 \\
1.9 \\
2.9 \\
3.9\end{array}$ & $\begin{array}{l}0.028 \\
0.028 \\
0.028 \\
0.028\end{array}$ & $\begin{array}{l}1.019 \\
1.039 \\
1.060 \\
1.080\end{array}$ \\
\hline 9.0 & $\begin{array}{l}1 \\
2 \\
3 \\
4\end{array}$ & $\begin{array}{l}0.9 \\
1.9 \\
2.9 \\
3.9\end{array}$ & $\begin{array}{l}0.003 \\
0.003 \\
0.003 \\
0.003\end{array}$ & $\begin{array}{l}1.042 \\
1.089 \\
1.134 \\
1.184\end{array}$ \\
\hline
\end{tabular}


Since the concentration of free cupric ion throughout the $\mathrm{pH}$ range used, apparently, was too low to cause inhibition and since the concentration of $1-1$ chelate species did not change when the $\mathrm{pH}$ of the equilibrium mixture was changed, any variation of inhibition could reasonably be attributed to charge changes on the enzyme surface. It was anticipated that if inhibition changed as a function of $\mathrm{pH}$, an optimum $\mathrm{pH}$ value would appear corresponding to the $\mathrm{pK}_{\mathrm{a}}$ of the group on the enzyme surface involved in the binding.

With the 2.1-1 ligand-metal ratio solution, the inhibition of the enzyme system at all $\mathrm{pH}$ values except $\mathrm{pH} 7.5$ followed a straight line relationship, passing through zero, when $\mathrm{Vo} / \mathrm{V}$ was plotted against $1-1$ chelate species concentration (Figure 10). At $\mathrm{pH} 7.5$, the resultant straight line did not pass through the origin but yielded, instead, a positive y-intercept. This odd behavior at pH 7.5 could possibly be attributed to a different mechanism inhibition or the presence of significant amounts of cupric ion in equilibrium with the enzyme. (It should be noted, however, that no time dependence was observed). $\mathrm{pH}$ values above and below the range of 7.5 to 9.0 could not be used, since the system was too highly buffered at low $\mathrm{pH}$ values and the chelate dissociated at high $\mathrm{pH}$ values. As can be seen in Figure 10, the inhibition appears to decrease as the $\mathrm{pH}$ is increased above 7.5 . In the $\mathrm{pH}$ range of 8.5 to 8.75 , the inhibition increases, possibly due to the fact that the $\mathrm{pK}_{\mathrm{a}}$ value 


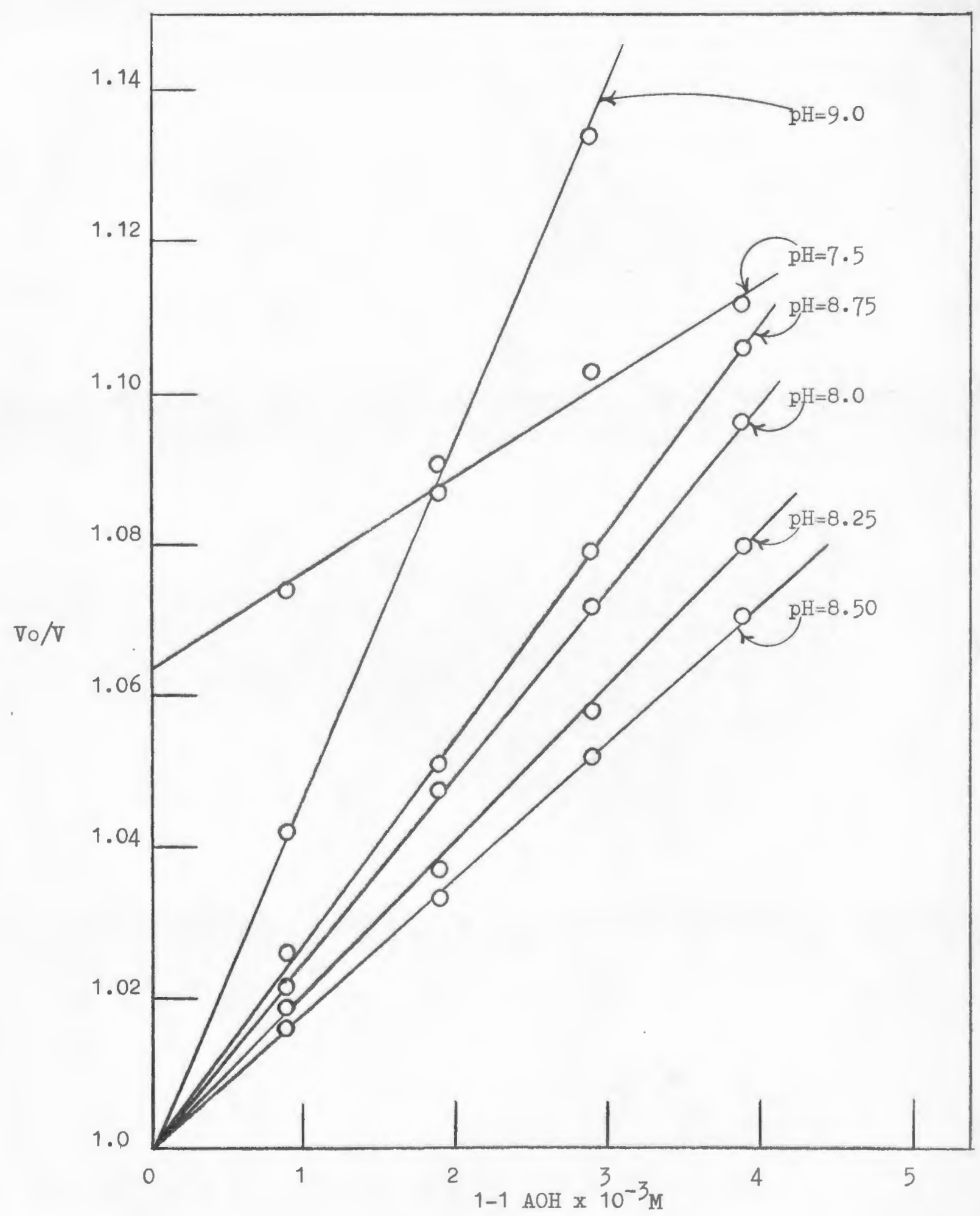

Figure 10. Comparison of inhibition by 1-1 AOH chelate at various $\mathrm{pH}$ values. The ratio of ligand-metal is 2.1-1. 
of the ionizing group on the enzyme surface involved in inhibitor binding, had been reached.

In order to substantiate these results, a 2.2-1 ligandmetal ratio solution was used as the inhibitor. This solution. has less free cupric ion but the concentration of 1-1 chelate species was the same as that present in the 2.1-1 mixture. It seemed reasonable to expect less inhibition with this ratio compared to the 2.1-1 ratio, if free cupric ion was contributing to the inhibition. The results of the inhibition studies at $\mathrm{pH}$ 8 and 8.5 are shown in Figure 11. The inhibition, expressed as $\mathrm{Vo} / \mathrm{V}$, was found to be the same, within experimental error, as the data obtained using the 2.1-1 ratio, under the assumption that the 1-1 species is the inhibitor. Thus, the possibility that free copper ion is contributing to the inhibition, seems unlikely.

In an attempt to elucidate the nature of the inhibition by the 1-1 chelate species, the $2.2-1$ ratio solution (at $\mathrm{pH}$ 8.5) was used to observe the inhibition of the enzyme at various substrate and inhibitor concentrations. (The choice of both the ratio of ligand to metal and the pH were arbitrary in this system, since the conoentration of 1-1 species did not change throughout the $\mathrm{pH}$ range under consideration, and free cupric ion concentration was negligible.) This procedure followed the general method of Michaelis and Menten (13) and the numerical results appear in Table VI. Graphical analysis of this data 


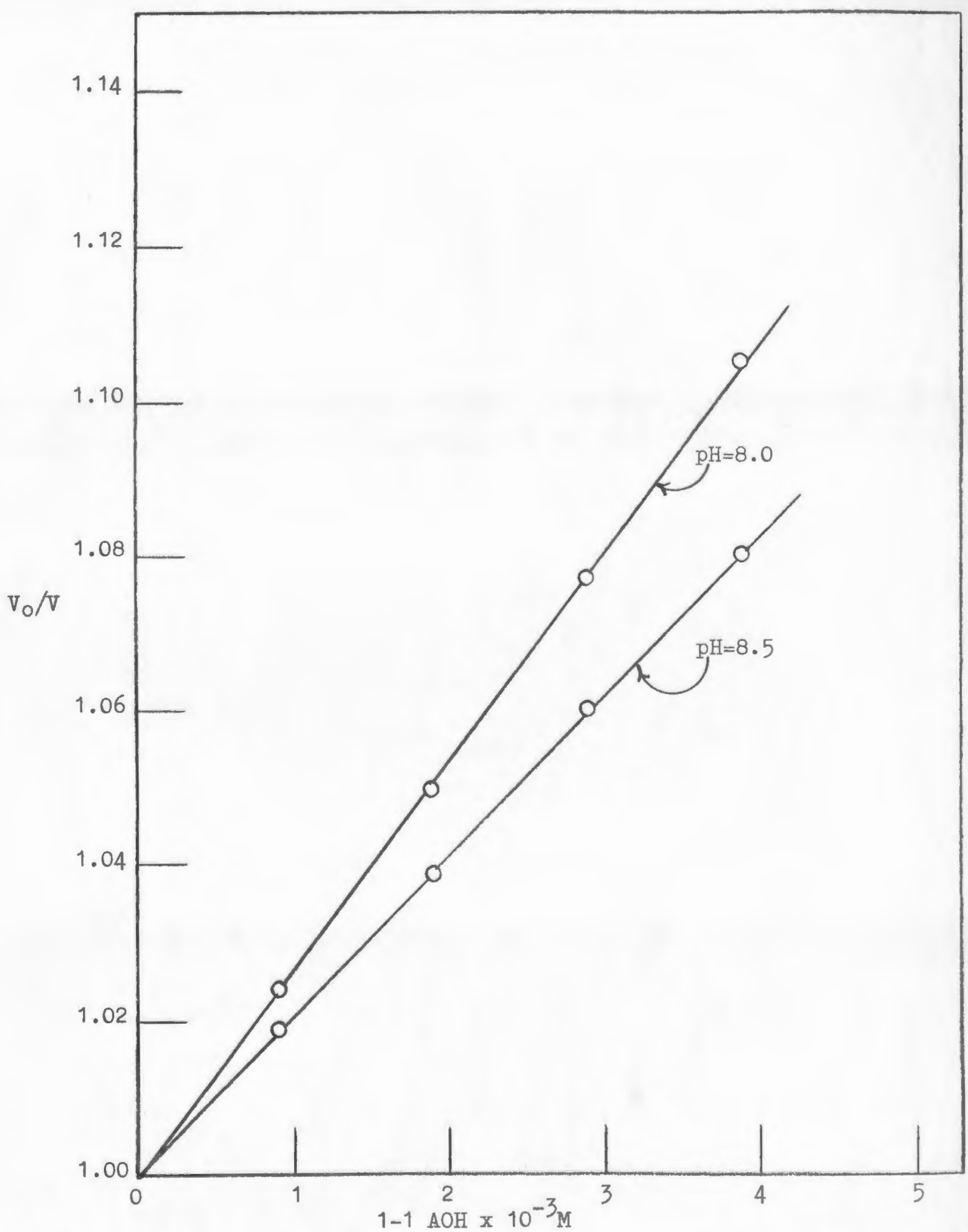

Figure 11. Comparison of inhibition by $1-1 \mathrm{AOH}$ chelates at pH. 8.0 and 8.5. The ratio of ligand-metal is $2.2-1$. 
TABLE VI

INHIBITION BY 1-1 AOH CHELATE IN A 2.2-1 LIGAND-METAL RATIO SOLUTION AT $\mathrm{pH} 8.5$ WITH VARYING SUBSTRATE CONCENTRATIONS

\begin{tabular}{|c|c|c|c|}
\hline $\begin{array}{l}\text { Molar } \\
\text { Conc. of } \\
\text { Substrate } \\
\times 10^{-3}\end{array}$ & $\begin{array}{l}\text { Molar Conc. } \\
\text { of Chelate } \\
\text { Mixture } \\
\times 10^{-3}\end{array}$ & $\begin{array}{l}\text { Molar Conc. } \\
\text { of } 1-1 \\
\text { Species } \\
\times 10^{-3}\end{array}$ & $\begin{array}{c}\text { Reaction } \\
\text { Velocity } \\
(1 / \mathrm{N})\end{array}$ \\
\hline \multirow[t]{5}{*}{1.22} & 0 & 0.0 & $49 \frac{1}{4}$ \\
\hline & 1 & 0.9 & $493 / 4$ \\
\hline & 2 & 1.9 & 51 \\
\hline & 3 & 2.9 & 52 \\
\hline & 4 & 3.9 & $53 \frac{1}{4}$ \\
\hline \multirow{6}{*}{0.99} & + & & \\
\hline & 0 & 0.0 & $50 \frac{\frac{\pi}{4}}{4}$ \\
\hline & 1 & 0.9 & 52 \\
\hline & 2 & 1.9 & 53 \\
\hline & 3 & 2.9 & $54 \frac{1}{4}$ \\
\hline & 4 & 3.9 & 57 \\
\hline \multirow[t]{5}{*}{0.73} & 0 & 0.0 & $533 / 4$ \\
\hline & 1 & 0.9 & $55 \frac{1}{4}$ \\
\hline & 2 & 1.9 & $57 \frac{1}{4}$ \\
\hline & 3 & 2.9 & $58 \frac{1}{4}$ \\
\hline & 4 & 3.9 & 62 \\
\hline \multirow[t]{5}{*}{0.49} & 0 & 0.0 & $58 \quad 3 / 4$ \\
\hline & 1 & 0.9 & $61 \frac{1}{4}$ \\
\hline & 2 & 1.9 & $63 \frac{1}{2}$ \\
\hline & 3 & 2.9 & 66 \\
\hline & 4 & 3.9 & 69 \\
\hline
\end{tabular}


according to the general procedure cutlired by Firiedenwald, et al. (18) appears in Figures 12 and 13. In this methud, values of $K_{I}, K_{S}$ and $\propto$ can be determiried (see Appendix $A$ ). When $\alpha$ is equal to infinity, the inhibition is termed completely "competitive" and when $\alpha$ equals unity, the inklbition is termed completely "non-competitive". Intermediate values of $\alpha$ indiats a combination or mixture u' both types of inhibition. The

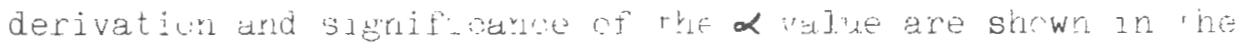
Appendix.

A multiple regression approach was used to fit the dat. This approach was used in all $\alpha$ determination studies and the: mathematical equations used appear in Appendix $A$. Analysis of Figures 12 and 13 indicates that the $1-1$ chelate of $\mathrm{AOH}$ inhibits the enzyme in a "competitive" marmer. Unfortunately, the overall inhibltion by this $1 \ldots 1$ chelate spectes

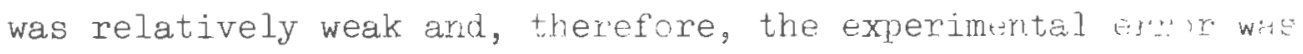
relatively large. Possible reason for this weak inhluthon are: (1) The 1-1 chelate species has orly a single plus rharge and (2) the terdentate attachuent j.nvolved in the formaticn of the 1-1 chelate species leaves only one available coordination site on the metal. The lack uf avalability of coordunation sites is probably an important factor, account nn for the weak inhibition properties; it had been previcusly reportod $(34,36)$ that 2-1 chelate species of $\mathrm{Cu}^{++}$, where there are no. coordination vacancies, did not appreciahly inhibit the enzyme. 


\section{5}

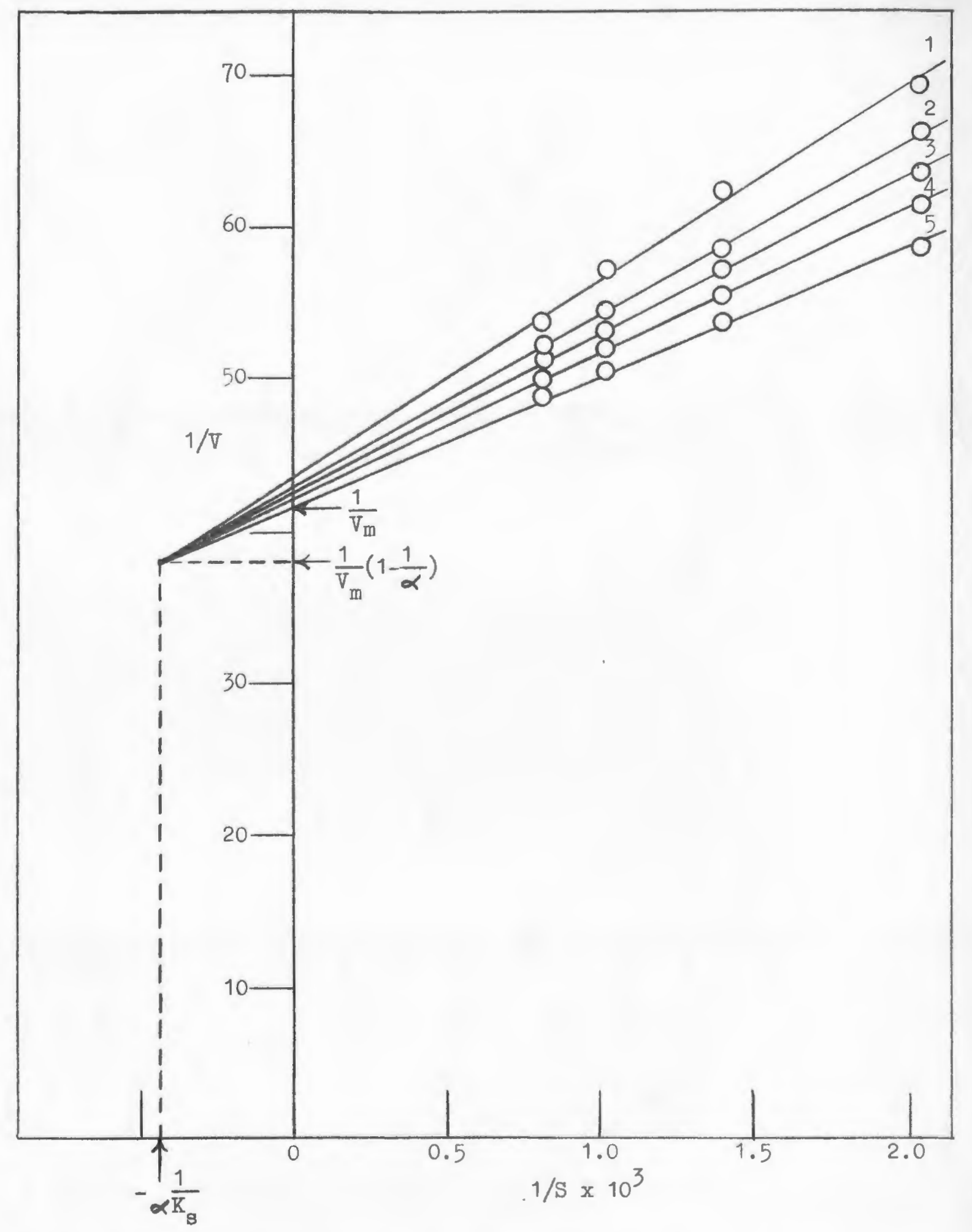

Figure 12. Analysis of inhibition by $1-1 \mathrm{AOH}$ chelate at $\mathrm{pH} 8.5$ using
$1 / \mathrm{s}$ values. Key: $1,(\mathrm{I})=3.9 \times 10^{-3} ; 2,(\mathrm{I})=2.9 \times 10^{-3}$; $3,(I)=1.9 \times 10^{-3} ; 4$, (I) $=0.9 \times 10^{-3} ; 5,(I)=0$. 


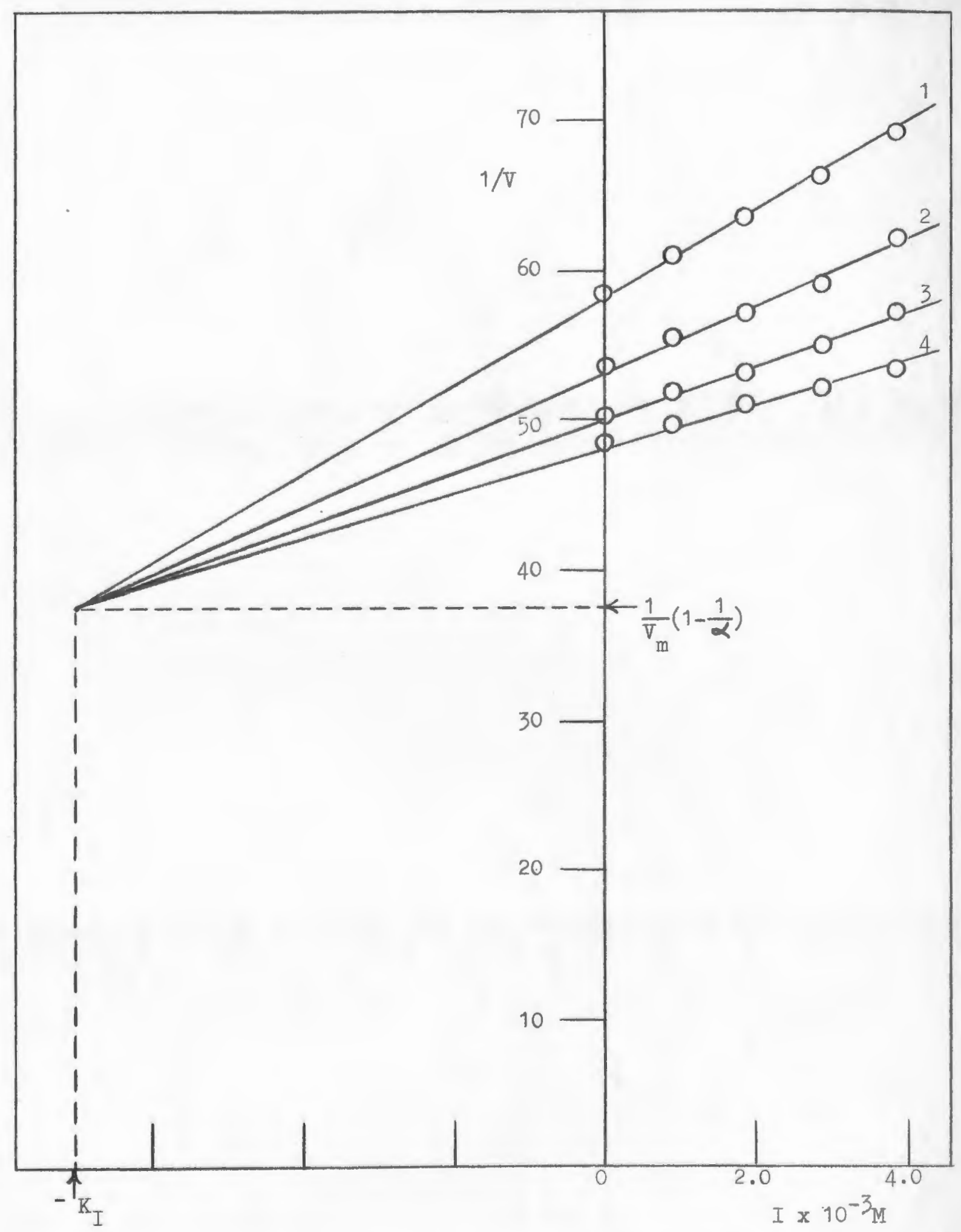

Figure 13. Analysis of inhibition by 1-1 AOH chelate at pH 8.5 using (I) values. Key: $1,(\mathrm{~S})=4.90 \times 10^{-4} \mathrm{M} ; 2,(\mathrm{~s})=7.30 \times 10^{-4} \mathrm{M}$; $3,(S)=9.90 \times 10^{-4} \mathrm{M} ; 4,(\mathrm{~s})=1.22 \times 10^{-3} \mathrm{M}$. 
Inhibition by the AH System. Analysis of the A.H syst.em was more complicated than the $\mathrm{AOH}$ system because of the presence of a stable 2-1 chelate species. Furthermore, the ligand-metal interaction of this chelate was much weaker than the AOH system (compare Figures 4 and 6), and, consequently, the selection of ligand-metal ratios and equilibrium $\mathrm{pH}$ values was restricted. Initially, $\mathrm{pH} 8.0$ was selected as the equilibrium $\mathrm{pH}$ for inhibition studies becarse a significant concentration of $1-1$ species was present at this pH. It was found that ligand-rietal ratios of 2.0-1 or less, could not be used at pH 8.0 because of the presence of relatively high concentrations of fref cupra: ion. In fact, at lower ratios, supric hydroxide precipitatuch was observed when the solations were allowed to stand for several days. When the ligand-metal ratio was raised to $2.1-1$ at $\mathrm{pl}$ 8.0, it was found that no precipitation occlurred and no time dependence was observed during inhibitory studies. For the above reasons, a 2.1-1 equilibrium chelate solution at, $\mathrm{pH} 8.0$ was chosen for the initial inhibition analysis of the AH system.

It was found that the concentration of 1-1 chelate spewies could be linearly correlated to inhibition, by plotting $\mathrm{V}_{u} / \mathrm{V}$ versus 1-1 concentration at pH 8.0. Figure 14 shows the results of this analysis. The 2-1 speczes did not seem ti contribute to the inhibition.

Because of the fact that the 1-1 chelate species seemed to be solely responsible for unhibition, under the abve con- 


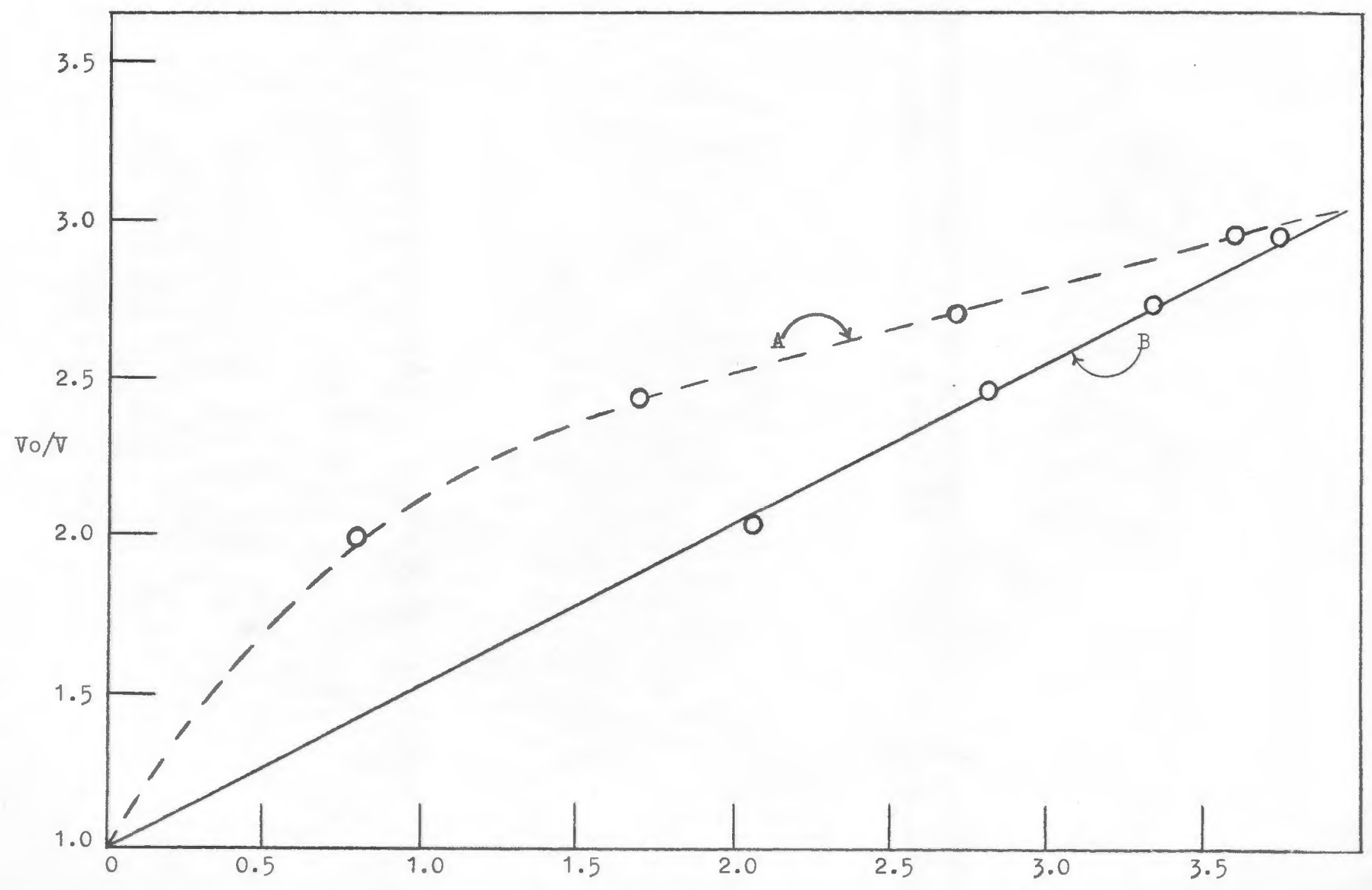

Figure 14. Inhibition by $1-1$ and 2-1 $\mathrm{AH}$ chelates at $\mathrm{pH} 8.0$. Abscissa taken as $10^{-3} \mathrm{M}$ for $2-1$ species and $10^{-4} \mathrm{M}$ for $1-1$ species. $\mathrm{A}, 2-1$ species; $\mathrm{B}, 1-1$ species. The ligand-metal ratio is $2.1-1$. 
ditions, an analysis to determine values of $K_{1}$ and $\alpha$ was attempted in a manrer sumilar to that described for the AOH system. The graphical results of this study appear in Figures $1 b$ and 16 and the concentrations of all species present in the equilibrium mixtures are shown in Table VII. Analyses of this data appeared to indicate a primarily "nor-competituve" type cf lraibiticr. To further elwidate the nature of irhibiticn by the 1-1 AH chelate, the inhibitin by solute ns containire l tand-metal ratios of $2.2-1$ and 2.7 was examined at $\mathrm{pH} 8.0$. A these nigher ratios, less free upric ion and smalles sil wh of $1-1$ species were present but the concentration of $2-$ ? species increased. The results of these studies, including concentrations of species present in the equilibrium mixture, are shown in Table VIII. The correlation of inhibition with 1-1 chelate species was quite good, over if the very low concentratiun of i-1 species is taken into account (Figure 17). At pH values higher tharı 8.0, it was not pussıle correlate either 1-1 or 2-1 chelate concentraikns witi jult:bition (see Figure 18). At elevated pH values, the expected straight line relationship was not obtained when either the 1-1 or 2-1 chelate concentration was plotted arainst Vo/V. It was found, however, that plots of the ratio of $1-1 / 2-1$ versis Vo/V yielded straight lines. Some possible explailations for this behavior are: (1) The double charge present m $\mathrm{Cu}^{++}$orslates of $\mathrm{AH}$ changes either the site on mechanism (i.e., the 


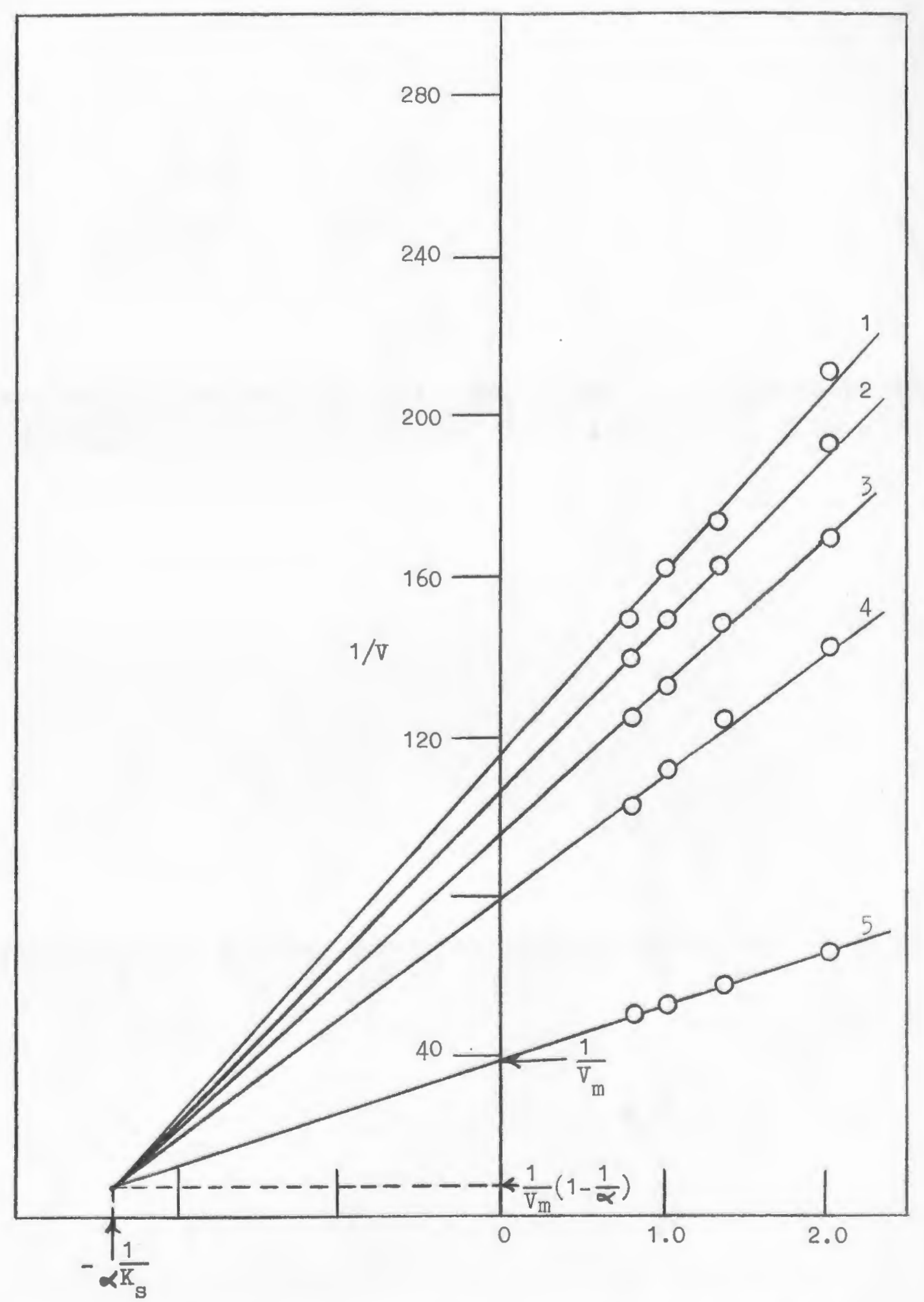

Figure 15. Analysis of inhibition by 1-1 $\mathrm{AH}$ chelate at $\mathrm{pH} 8.0$ using $1 / \mathrm{s}$ values. Key: $1,(I)=3.73 \times 10^{-4} \mathrm{M} ; 2,(\mathrm{I})=$ $3.34 \times 10^{-4} \mathrm{M} ; 3$, (I) $=2.82 \times 10^{-4} \mathrm{M} ; 4,(I)=2.06 \times 10^{-4} \mathrm{M}$; $5,(I)=0$. 


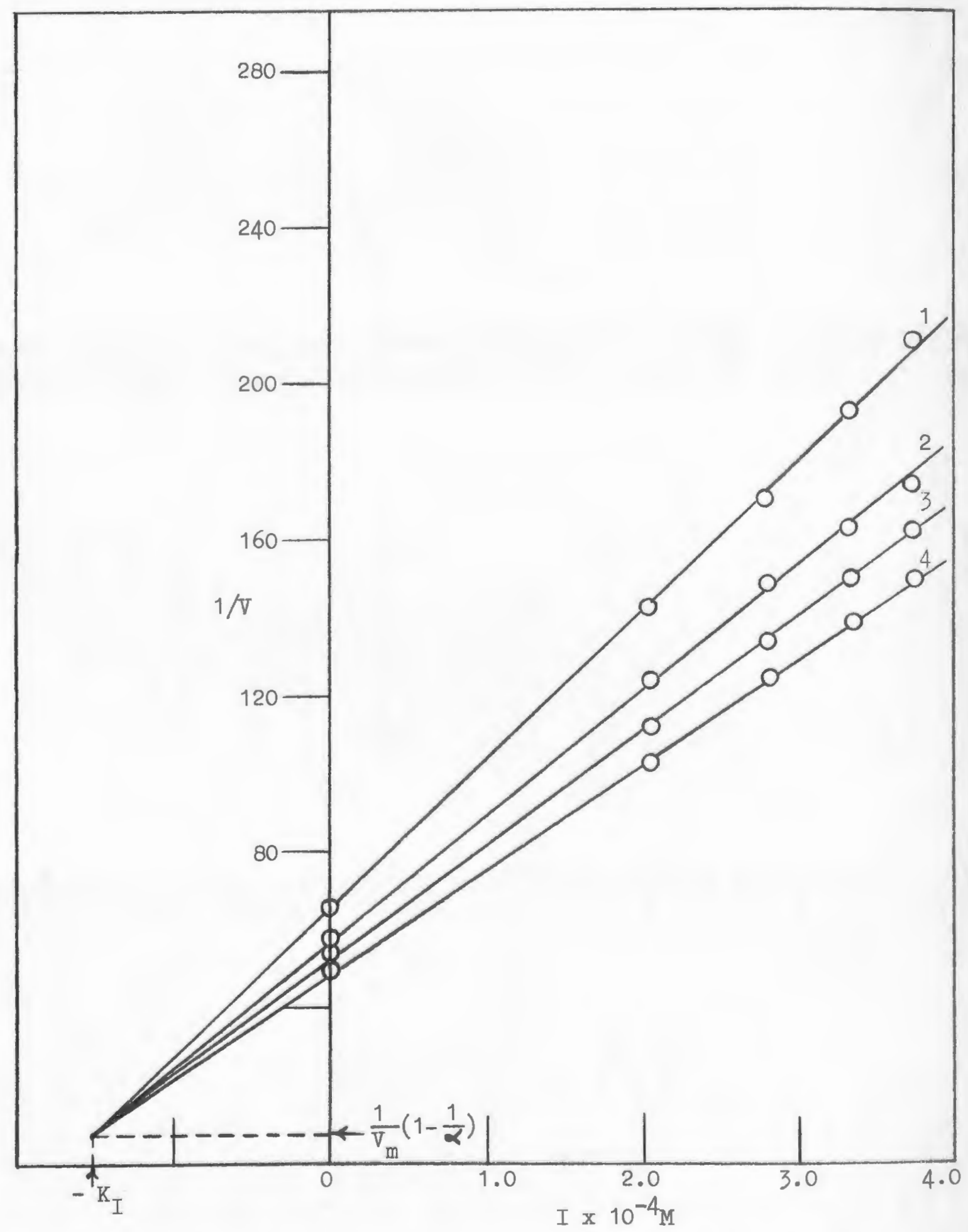

Figure 16. Analysis of inhibition by 1-1 AH chelate at $\mathrm{pH} 8.0$ using (I) values. Curves 1-4 have the same meanings as in Figure 13. 


\section{TABLE VII}

TNHIBITION BY 1-1.AH CHELATES IN A 2.1-1 LIGAND-METAL RATIO SOLUTION AT pH 8.0 WITH VARYING SUBSTRATE CONCENTRATIONS

\begin{tabular}{|c|c|c|c|c|c|}
\hline $\begin{array}{l}\text { Molar } \\
\text { Conc. of } \\
\text { Substrate } \\
\times 10^{-3}\end{array}$ & $\begin{array}{l}\text { Molar Conc. } \\
\text { of Chelate } \\
\text { Mixture } \\
\times 10^{-3}\end{array}$ & $\begin{array}{l}\text { Molar Conc. } \\
\text { of Free } \\
\text { Cupric Ion } \\
\times 10^{-7}\end{array}$ & $\begin{array}{l}\text { Molar Conc. } \\
\text { of } 1-1 \\
\text { Species } \\
\times 10^{-4}\end{array}$ & $\begin{array}{l}\text { Molar Conc. } \\
\text { of } 2-1 \\
\text { Species } \\
\times 10^{-3}\end{array}$ & $\begin{array}{l}\text { Reaction } \\
\text { Velocity } \\
\qquad(1 / \mathrm{V})\end{array}$ \\
\hline \multirow[t]{5}{*}{1.22} & 0 & 0.00 & 0.00 & 0.00 & $50 \frac{1}{2}$ \\
\hline & 1 & 2.50 & 2.06 & 0.79 & 101 \\
\hline & 2 & 2.17 & 2.82 & 1.72 & $124 \frac{1}{2}$ \\
\hline & 3 & 1.96 & 3.34 & 2.67 & 138 \\
\hline & 4 & 1.79 & 3.73 & 3.63 & . 149 \\
\hline \multirow[t]{5}{*}{0.99} & 0 & 0.00 & 0.00 & 0.00 & 53 \\
\hline & 1 & 2.50 & 2.06 & 0.79 & 111 \\
\hline & 2 & 2.17 & 2.82 & 1.72 & 133 \\
\hline & 3 & 1.96 & 3.34 & 2.67 & 148 \\
\hline & 4 & 1.79 & 3.73 & 3.63 & 161 \\
\hline \multirow[t]{5}{*}{0.73} & 0 & 0.00 & 0.00 & 0.00 & $57 \frac{1}{2}$ \\
\hline & 1 & 2.50 & 2.06 & 0.79 & 125 \\
\hline & 2 & 2.17 & 2.82 & 1.72 & $148 \frac{1}{2}$ \\
\hline & 3 & 1.96 & 3.34 & 2.67 & 162 \\
\hline & 4 & 1.79 & 3.73 & 3.63 & $170 \frac{1}{2}$ \\
\hline \multirow[t]{5}{*}{0.49} & 0 & 0.00 & 0.00 & 0.00 & $65 \frac{1}{2}$ \\
\hline & 1 & 2.50 & 2.06 & 0.79 & 142 \\
\hline & 2 & 2.17 & 2.82 & 1.72 & 169 \\
\hline & 3 & 1.96 & 3.34 & 2.67 & 192 \\
\hline & 4 & 1.79 & 3.73 & 3.63 & 211 \\
\hline
\end{tabular}




\section{TABLE VIII}

INHIBITION BY 1-1 AH CHELATE IN 2.2-1 and 2.3-1 LIGAND-METAL RATIO SOLUTIONS AT pH 8.0 WITH A SUBSTRATE CONCENTRATION OF

$$
1.22 \times 10^{-3} \mathrm{M}
$$

\begin{tabular}{|c|c|c|c|c|}
\hline $\begin{array}{l}\text { Molar Conc. } \\
\text { of Chelate } \\
\text { Mixture } \\
\times 10^{-3}\end{array}$ & $\begin{array}{l}\text { Molar Conc. } \\
\text { of Free } \\
\text { Cupric Ion } \\
\times 10^{-7}\end{array}$ & $\begin{array}{l}\text { Molar Conc. } \\
\text { of } 1-1 \\
\text { Species } \\
\text { x } 10^{-4}\end{array}$ & $\begin{array}{l}\text { Molar Conc. } \\
\text { of } 2-1 \\
\text { Species } \\
\times 10^{-3}\end{array}$ & Vo/V \\
\hline \multicolumn{5}{|c|}{ Ligand-Metal Ratio=2.2-1 } \\
\hline 0 & 0.00 & 0.00 & 0.00 & 1.00 \\
\hline 1 & 1.73 & 1.75 & 0.83 & 2.09 \\
\hline 2 & 1.34 & 2.25 & 1.78 & 2.39 \\
\hline 3 & 1.11 & 2.55 & 2.75 & 2.67 \\
\hline 4 & 0.95 & 2.75 & 3.73 & 2.92 \\
\hline \multicolumn{5}{|c|}{ Ligand-Metal Ratio=2.3-1 } \\
\hline 0 & 0.00 & 0.00 & 0.00 & 1.00 \\
\hline 1 & 1.24 & 1.50 & 0.85 & 2.04 \\
\hline 2 & 0.87 & 1.84 & 1.82 & 2.37 \\
\hline 3 & 0.68 & 2.02 & 2.80 & 2.64 \\
\hline 4 & 0.56 & 2.13 & 3.79 & 2.80 \\
\hline
\end{tabular}




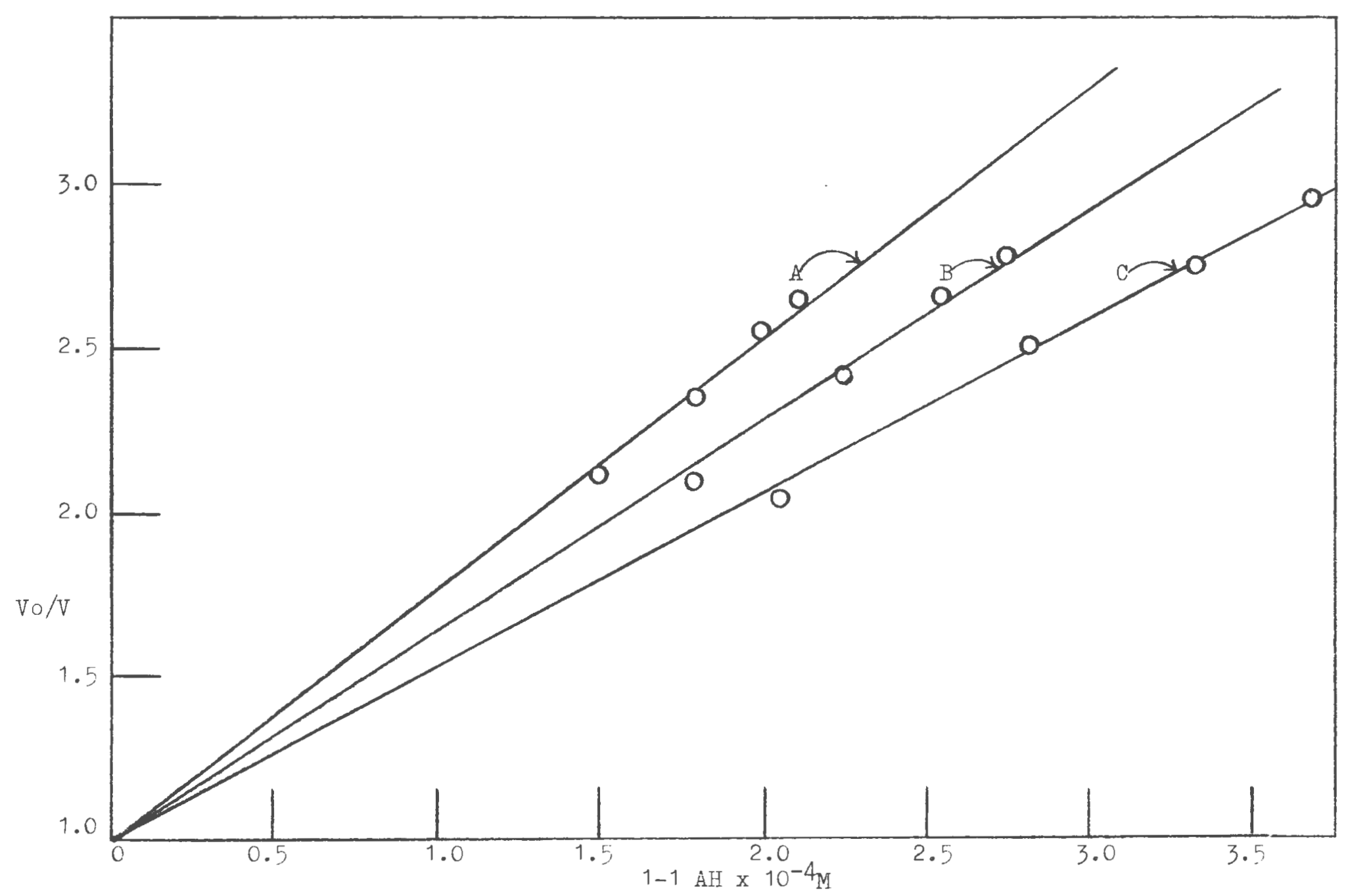

Figure 17. Inhibition by 1-1 AH chelate in several ligand-metal ratios at pH 8.0 . A, ligandmetal ratio $2.3-1$; $B$, ligand-metal ratio $2.2-1$; $C$, ligand-metal ratio $2.1-1$. 


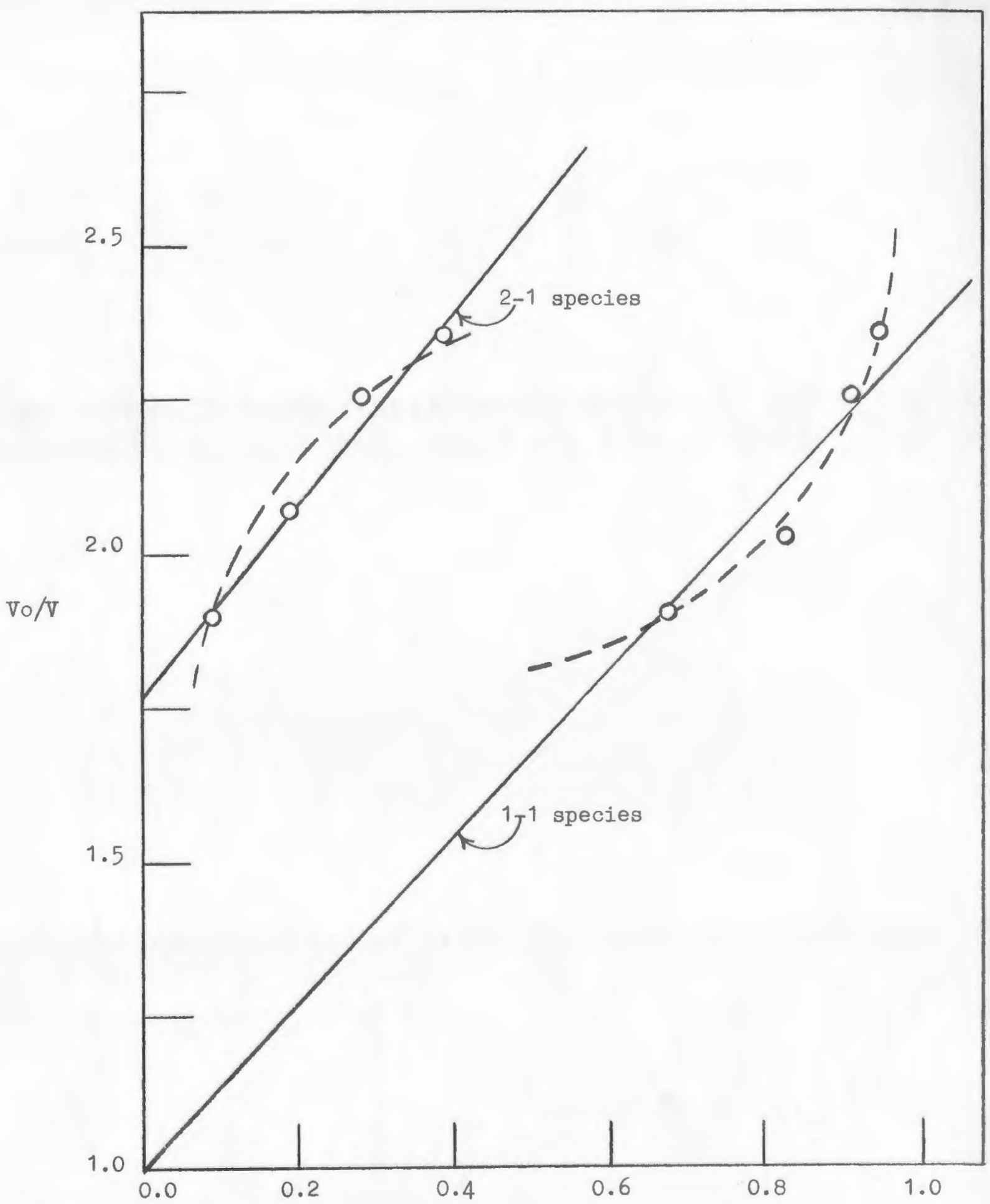

Figure 18. Inhibition by $1-1$ and 2-1 $\mathrm{AH}$ chelates at $\mathrm{pH} 8.5$. For 1-1 species, abscissa represents $10^{-4} \mathrm{M}$; for $2-1$ species, abscissa represents $10^{-3} \mathrm{M}$. 
mechanism no longer follows Michaelis and Menten kinetics) of binding on the enzyme surface at elevated $\mathrm{pH}$ values and/or (2) the concentration of 1-1 chelate species was so small compared to 2-1 chelate that an equilibrium was achieved between the enzyme and the chelate solution according to the following scheme:

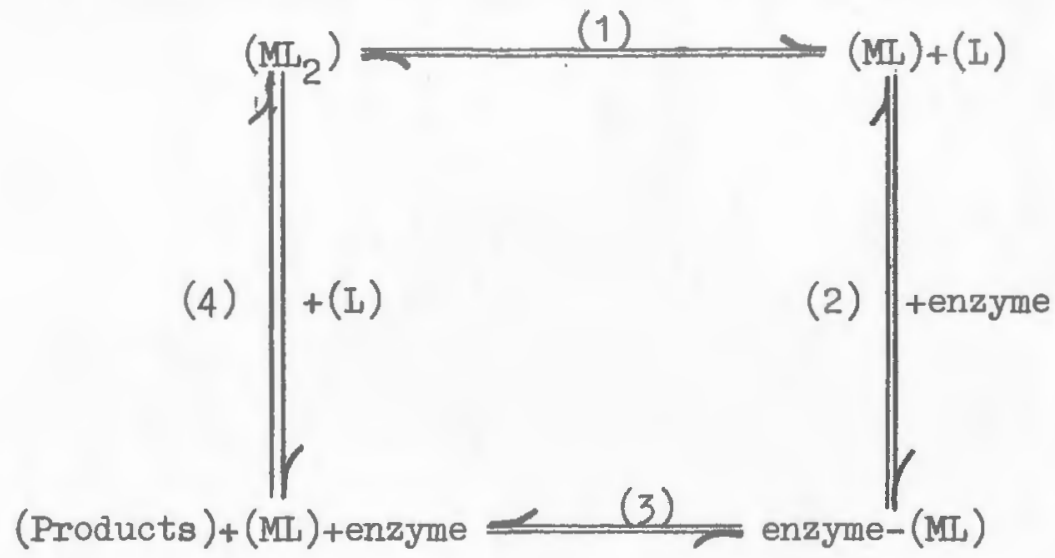

Because of this behavior, it was not possible to determine $\alpha$ and $\mathrm{K}_{\mathrm{I}}$ values for the $\mathrm{AH}$ system at elevated $\mathrm{pH}$ values. Inhibition by the HP System. Analysis of the HP system was conducted in a manner similar to that úsed for the $\mathrm{AH}$ system. Here, again, both a 1-1 and 2-1 chelate species were formed with stability constants much weaker than the $\mathrm{AOH}$ interaction, (compare Figures 4 and 8 ). Consequently, the selection of ligandmetal ratios and equilibrium $\mathrm{pH}$ values were again restricted. 
Initially, a ligand-metal ratic of 2.0-1 was examined at $\mathrm{pH}$ 8.0. This ratio and $\mathrm{pH}$ resulted in rather large cuncentrations of 1-1 species and apparently insignificarıt amounts of tree cupric ion in the equilibrium mixture. It was found, however, that although the equilibriun mixture at this pH exhibited no time dependenct, a plot of 1-1 chelate species versus Vo/v yielded a straight line with a positive $y$-irtercept. The "extra" ir.hirj: zor, rut accunted for by the 1-1 species, acald possibly be attributed to tree cupric ion present at pH 8.0 . Since possible interference by fret cuprac ion was suspected at pH 8.0, the 2.0-1 ligand-metal rat lo wis oxdmined at pH 8.25. At this slightly higher pH, the influerce of free cupric ion might be eliminated.

The results of the experiment at pH 8.25 with a ligandmetal ratio of 2.0-1 are shown in Figure 19. Examination of this data revealed that, apparently, a critical concentiation of 1-1 species was necessary before any inklbit lon cocurred. Once this critical concentration was reached, the lnhibiticn followed a straight line relatiurship tur 1-1 concentration versus Vo/v.

In order to substantiate this unusual observatior, Ii gandmetal ratios of $2 \cdot 1-1$ and $2 \cdot 3-1$ were prepared. These mixtures contained less free cupric ion and less $1-1$ chelate species but more 2-1 chelate species at equlibrium. The result of this study, including all pertinent concentrations, appears in 


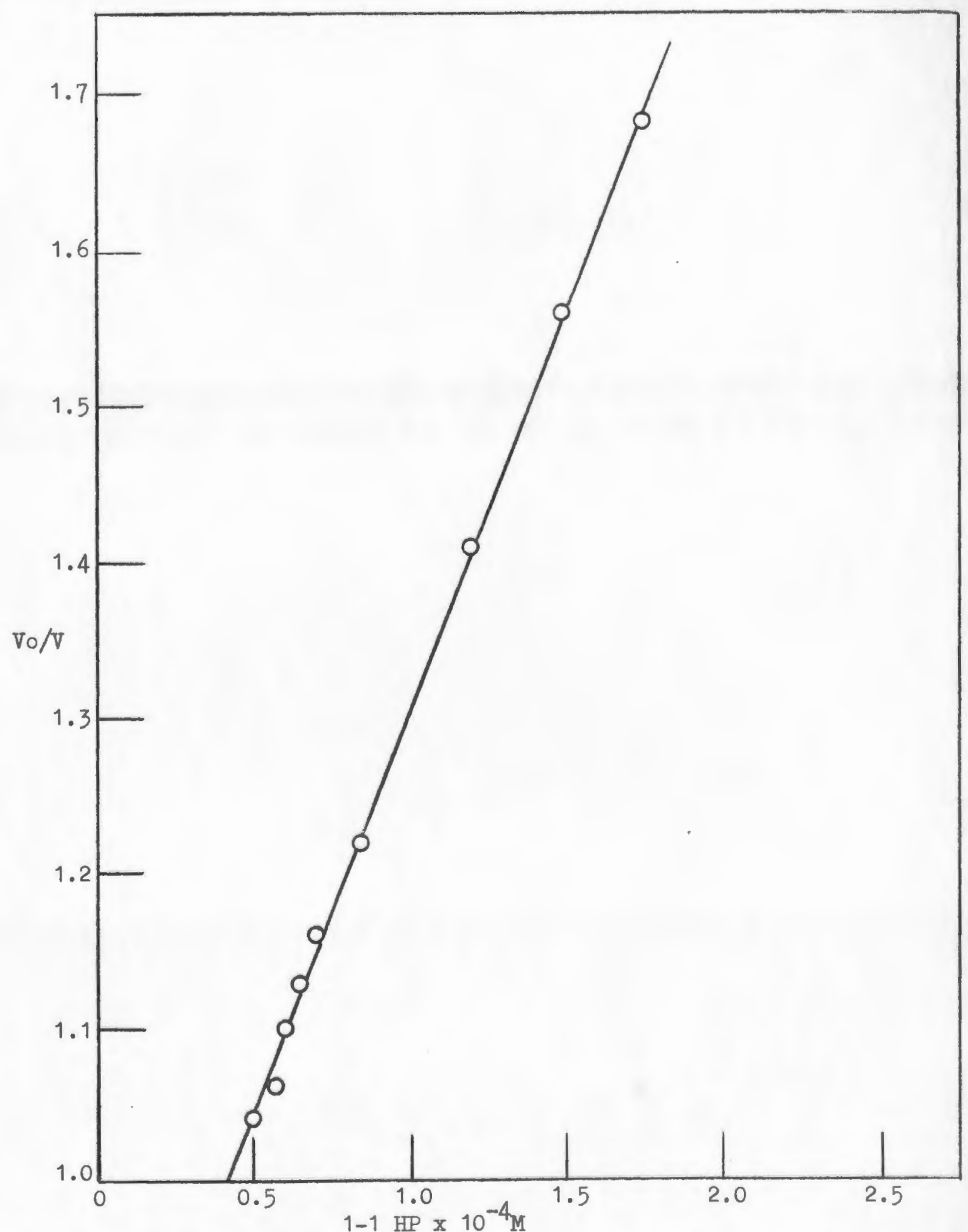

Figure 19. Inhibition by 1-1 HP chelate in several ligand-metal ratios at $\mathrm{pH}$ 8.25. 
Table IX (see also Figmre 19). Aralysis of this data indicated a consistent correlation between 1-1 chelate concentration and Vo/V among the solutions of different ligand-metal ratios. For example, low concentrations of the 2.3-1 Ligand-metal ratio solution, which contairsed, at equilibrium, amounts of the 1-1 chelate species almost identrcal with the "yield value" or critical concentration, showed practically no inhibitory activity. When the $\mathrm{pH}$ was incressed to 8.5, not crily did the "yıld value" disappear, but, as in the case of $\mathrm{AH}$, correlation of $1-$ ! species and inhibition could not be made. Possibly another mechanism of binding to the enzyne surface or an actual physiochemical change of the er:zyme was responsible for this odd behavior. It should be noted that previous studies of the acetylcholinesterase system by Bolton $(34,36)$ were conducted at $\mathrm{pH}$ values of 7.0 and 8.0 and, consequently, none of the unusual behavior observed in our studies at equilıbrium pH values of 8.5 and higher, had been encounteited. Although the reasun for the occurrence of a "yleld vilue" in this study is not known, ore possible explanatıor could be made on the basis of steric hindrance. The IH ligand was the only ring compound studied and the chelates formed were dokkle ring structures. Possibly the relatively large size of the: 1-1 chelate prevented easy attachment to the enzyme site involved. in binding. At higher pH values the charge of the binding site on the enzyme surface might have changed, thereby elininating" 
TABLE IX

INHIBITION BY $1-1$ HP CHEIATE IN SEVERAL LIGAND-METAL RATIO SOLUTIONS AT PH 8.25 WITH A SUBSTRATE CONCENTRATION OF

$$
1.22 \times 10^{-3} \mathrm{M}
$$

\begin{tabular}{|c|c|c|c|c|}
\hline $\begin{array}{l}\text { Molar Conc. } \\
\text { of Chelate } \\
\text { Mixture } \\
\times 10^{-3}\end{array}$ & $\begin{array}{l}\text { Molar Coric. } \\
\text { of Free } \\
\text { Cuprie: Ion } \\
x 10^{-7}\end{array}$ & $\begin{array}{c}\text { Molar Cone. } \\
\text { of } 1-1 \\
\text { Species } \\
\text { x } 1:^{-4}\end{array}$ & $\begin{array}{c}\text { Molar Conc. } \\
\text { of } 2-1 \\
\text { Species } \\
x 10^{-3}\end{array}$ & $\mathrm{~V} e / \mathrm{V}$ \\
\hline \multicolumn{5}{|c|}{ Licand-Metal Ratic $=2 \cdot 0-1$} \\
\hline $\begin{array}{l}0 \\
1 \\
2 \\
3 \\
4\end{array}$ & $\begin{array}{l}0.00 \\
1.699 \\
1.701 \\
1.702 \\
1.703\end{array}$ & $\begin{array}{l}0.00 \\
0.85 \\
1.22 \\
1.50 \\
1.74\end{array}$ & $\begin{array}{l}0.00 \\
0.91 \\
1.88 \\
2.85 \\
3.83\end{array}$ & $\begin{array}{l}1.00 \\
1.22 \\
1.41 \\
1.56 \\
1.68\end{array}$ \\
\hline \multicolumn{5}{|c|}{ Ligand-Metal Riatio $=2 \cdot 1-1$} \\
\hline $\begin{array}{l}0 \\
1 \\
2 \\
3 \\
4\end{array}$ & $\begin{array}{l}0.00 \\
0.570 \\
0.391 \\
0.300 \\
0.245\end{array}$ & $\begin{array}{l}0.00 \\
0.502 \\
0.591 \\
0.641 \\
0.670\end{array}$ & $\begin{array}{l}0.00 \\
0.95 \\
1.94 \\
2.94 \\
3.93\end{array}$ & $\begin{array}{l}1.00 \\
1.05 \\
1.10 \\
1.15 \\
1.16\end{array}$ \\
\hline \multicolumn{5}{|c|}{ Ligand-Metal Ratio $=2.2-1$} \\
\hline $\begin{array}{l}0 \\
1 \\
2 \\
3 \\
4\end{array}$ & $\begin{array}{l}0.00 \\
0.242 \\
0.140 \\
0.099 \\
0.077\end{array}$ & $\begin{array}{l}0.00 \\
0.240 \\
0.250 \\
0.256 \\
0.258\end{array}$ & $\begin{array}{l}0.00 \\
2.97 \\
1.96 \\
2.96 \\
3.96\end{array}$ & $\begin{array}{l}1.00 \\
1.004 \\
0.97 \\
1.01 \\
1.05\end{array}$ \\
\hline
\end{tabular}


this steric effect, resulting in the disappearance of the "yield value."

Correlation of the Inhibition Studies. In this section, an attempt will be made to discuss various factors which may affect inhibitory activity within each ligand system. Also, any deviations from expected results, not previously discussed, will be cited.

Relation of Inhibition to Stability Constants. The chelate stability constants for the three ligands under consideration, appear in Table $X$. It is difficult to make a complete comparison of the extent of inhibition with formation constants because of the yield value encountered with the HP system. The $\mathrm{AOH}$ system exhibited the weakest inhibitory action among the three ligands and it had the largest formation constant. If the availability of the metal ion is essential for inhibition, the weak inhibitory properties of the AOH ligand might be expected because of the (1) high stability constant and (2) shielding of the metal in the terdentate attachment. Table X also contains the formation constants for the ethylenediamine and glycine ligand systems reported by Bolton $(34,36)$. It would have been convenient if all systems could have been examined at the same $\mathrm{pH}$, but because of various factors previously discussed, this was not possible. Examination of Table $X$ reveals a possible relationship between the formation constants $\left(K_{1}\right)$ and the in- 
TABLE X

RELATION OF CHELATE STABILITY CONSTANTS $\left(\mathrm{K}_{1}\right)$ TO INHIBITION CONSTANTS $\left(K_{I}\right)$

\begin{tabular}{|c|c|c|c|c|c|c|}
\hline Ligand & $\log \mathrm{K}_{1}$ & $\mathbf{K}_{\mathbf{I}}$ & $\mathrm{K}_{\mathrm{s}}$ & & $\mathrm{pH}$ & Charge \\
\hline $\mathrm{AOH}$ & 14.20 & $6.95 \times 10^{-3}$ & $1.91 \times 10^{-4}$ & 10.8 & 8.5 & $(+)$ \\
\hline $\mathrm{AH}$ & 9.29 & $1.5 \times 10^{-3}$ & $3.39 \times 10^{-4}$ & 1.25 & 8.0 & $(++)$ \\
\hline $\mathrm{HP}$ & 8.00 & $\cdots \cdots$ & $\ldots$ & $\ldots$ & $\cdots$ & $(+)$ \\
\hline \multicolumn{7}{|c|}{ Literature (34) } \\
\hline $\begin{array}{c}\text { Ethylene- } \\
\text { diamine }\end{array}$ & $10 \cdot 34$ & $1.9 \times 10^{-4}$ & $\cdots \cdots$ & 1.0 & 8.0 & $(++)$ \\
\hline Glycine & 8.20 & $1.9 \times 10^{-4}$ & $\cdots$ & 1.3 & 8.0 & $(+)$ \\
\hline
\end{tabular}


hibitory constants $\left(K_{I}\right)$. (The calculation of $K_{I}$ values is discussed in the Appendix, in the section dealing with $\alpha$ determinations.) It appears that high $K_{1}$ values resilt in low $K_{I}$ values. Bolton, however, calculated identical values for $K_{I}$ when he compared ethylen-diamne and slycine, although the chelate stability corstants are quite diflerent. Trus, althourh there appears to be some rulationship between $K_{1}$ ardd $K_{I}$, ct.ter factors are urdoubtedly lriviluad.

Relation of Inhibition to Charge. Althourh the charge associated with the chelate suecies nay have an effect on binding, it is not possible to measure this effect at a given equilibrium pH. Also, comparisons of charge and inhilition among all three ligands at pH 8.0 may not he meaningful, since the mechanism of chelate attachmert to the enzyme surface may be different for each system. It will be demonstrated that char : may become a very sionfficant factor in the extent of birding at elevated pH values.

pH Effects on Inhibition. When equilibrium pH was altered, the extent of irhibition changed in all systems studied. In the $\mathrm{AOH}$ system, where the concentration or 1-1 speries did not change over a large pH range, studies were made at several equilibrium pH values. These results appear i.r. Fispre 10 and indicate a strong dependence of inhibitior wn equilibram pH. The data shows a dramatic change in inhibitory actuvity betwen 
$\mathrm{pH} 8.50$ and 8.75. Possibly the $\mathrm{pK}$ a of the group on the enzyme surface involved in the binding process ouurs ir this pH ranto The overall inhibition noted by the AOH system was quite low until elevated $\mathrm{pH}$ values were ixed. Conseivably, the charge effect becomes a predominant factor at nigher pll values and supercedes other mechanisms of attachment which nay occur at lower pH valizes.

It is of iriterest to r. te that tre 1-1 AH clielata Is doubly chared and the system was tound to be very pH deperidert. At pH 8.0, a correlation of 1-1 specres wath lihibition seemed evident, but at slightly higher pH values this relationshlp did not exist. For example, plots of 1-1 AH chelate concentration versus Vo/V at $\mathrm{pH} 8.5$ resulted in curved Iines. Because of this result, the inhibition data obtained under these ourditions could not be analyzed. As was mentioned earlier, attempts to run studies at lower equllibrıum pH values resulted jr. free cupric ion interference.

The possibility that a dif'erent merharism of irstibitson or a change of binding site us involved at elevated pei values seems reasonable. The fact that this curvatures was rot obst rvid in the $\mathrm{AOH}$ system, at elevated pH values, may possirly be atributed to the single positive charge on the 1-1 AOH chelates as compared to the doubly positive charge on the 1-1 Af chelates. Furthermore, the fact that the concertration ri $1-1$ species is quite small in comparisor to the $2-1$ species at eltvated 
$\mathrm{pH}$ values may cause a significart equilibrium shift (see page 66. .)

Examination of the HP systen at different $\mathrm{pH}$ values was not possible. At $\mathrm{pH}$ values below 8.2b, free cixpric ion interfered and at pH values of 8. , or hipher the stability of the chelates was questicnable. The results obtainf at pH 8.5 have not been included because they were not reproducible.

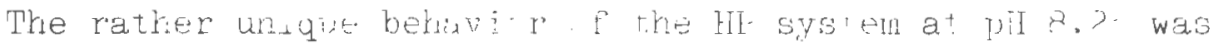
reproducible and will be discussed later.

Relation of Coordination Vacancies and Inhibiticn. Whe fact that coordination vacancies must be present on the metal ion in order to observe inhibition, was observed in al? three systems. The weak inhibitory activity of the $\mathrm{AO}^{\mathrm{COCu}}{ }^{+}$chelate could be attributed to the presence of only one courdination vacancy on the $\mathrm{Cu}^{++}$. The absence of inmibltury activity $\mathrm{C}, \mathrm{f}$ the 2-1 AH and HP chelates may be attributed th the ansentet of any coordination vacarcies. It is possible, however, that 1 t the metal ion itself is attaching to the enzyme surface, the 2-1 chelates present a sterically blucked cuprio icn arıd privent the attachment f'rom occurrirtés (except at elovated pH vai a., with doubly charged chelates, sic AH systen).

Relation of Configuration and Inhibition. I'le straingl. terdentate attachment of the $\mathrm{AO}-\mathrm{Cu}^{+*}$ chelate has beer descrived. The large formation curstart calculated for this ohelate would 
probably result in very little rotation within the molecule and, consequently, the metal ion would not be readily available for attachment to the enzyme surface.

The AH system presented an unstrained six member chelate ring in the 1-1 species. Thus, the copper ion in this compound was available for attachment to the binding site on the enzyme surface. However, this availability of copper ion was superceded at elevated $\mathrm{pH}$ values, probably because of the double charge on the chelate molecule.

The HP system was interesting in that it is the only ligand examined which contained a ring. This ring configuration may be the basis of a possible explanation for "yield" value (or critical concentration requirement) observed at $\mathrm{pH} 8.25$. When the 1-1 HP chelate forms, a double ring compound results which could present a steric hindrance in attaching to the enzyme surface. Possibly, a critical concentration of the 1-1 HP species was necessary to overcome this steric effect, before any inhibition could be observed. Initially, the configuration of the hydroxy group in HP was thought to be of possible value in increasing inhibition because it could be directed towards the esteratic site on the enzyme. Unfortunately, the limited pH range in which this compound could be studied, prevented the design of experiments which could possibly have elucidated effects of this hydroxy group. 


\section{IV . SUMMARY}

An attempt at the systematic aralysis of acetylinslinesterase inhibition by copper chelates, is presented. Frevious analyses of enzyme-chelate interactions have been limited ta $\mathrm{pH}$ values of 7.0 and 8.0 , resulting in "ncn-ounpetitive" inhibition by 1-1 chelate spocies.

It is shown that, tro 1-1 crelate species of 1,3 dianinpropare di-HCi inhiojts in a "nor-oompe + i ive" máne at, pH 8.0. At highter pH ralues, the relatuorshzp between enzyme reaction velocity and concentration of 1-1 species is no longer linear, indicating a different mechanism of inhibition is occurring.

It is shown that the 1-1 chelate spevies of 1,3 diaminopropanol-2 inhibits in an essentially "competitive" manner at. pH 8.5. Further, a relationship between inhibition and plI is developed for the 1,3 diaminopropanol-2 eystem resiltin. i. increased inhibition in the $\mathrm{pH}$ rarge 8.010-8.75. Aralys 150. data indicates a change in charge at tre binding sites on tie enzyme surface in this $\mathrm{pH}$ rarge.

It is shown that 1-1 copper chelates of hydroxy-L-proliye inhibit the enzyme at $\mathrm{pH} 8.25$, after a critical concentratin of 1-1 species is reached. At lower pH values, tree cuprid it. interfers and the chelate speuies dissociates at pH values anve 8.25. The yield value encountered in the bydroxy-l-pioline system precludes the use of ijost-onder enzyme kiretid trieory 
to analyse the data. The yield value may be attributed to steric factors resulting from the formaticr of a double ring system in the 1-1 chelate.

The effects of tree cupris icr are examined in all systems. Results indicate the oncertration of free copric ion is depertdent on the formation constant and the pH if the equilibrium mixture. It is further show that conentrations of expric ion below $1 \times 10^{-6} \mathrm{M}$ extibit $n=$ irkisht ry propties.

The relationship between intibit, on an coordination vacancies is examined in all systems. In agreemert with previous results, the presence of vacarcies or the metal ion is essential for inhibition. The $\mathrm{AOH}$ chelate, with cnly une wo.. ordination vacancy on the metal ion, is a weak irhibitor. 2-1 chelates of both AH ard HP, with no coordination vacancies on! the metal ion, did not appear to inhinit the enzyme sigrificarity.

The effect of chelate charge is examined in all three systems. The charge on the 1-1 AOH chelate, (a sirele positive charge) is analysed as a furction of $\mathrm{pH}$ and the data has been discussed earlier. The instability of the 1-1 HP chelate (alss with a single positive charge) did not allow equilikrium $\mathrm{pH}$ changes and consequently ro correlation ketweer intitition and charge car be made. The 1-1 AH chelate (with a doukle positive charge) is shown to exhibit ron-ideal heravior at elevated $\mathrm{pH}$ values. The presence of the dcuble positive harde or a change in the mechanism of hinding to the enzyme surface may be factors responsible for this behavicr. 


\section{BIBLIOGRAPHY}

1. Wilson, I.B., Biochem. et Biophys. Acta, I. 466 (1951).

2. Brecher, A.S., and Baker, B.S., Biochem. Fharmacol., 14, 638 (1956).

3. Salas, M.L., Vinuela, E., Salas, M., and Sols, A., Biochem. et Biophys. , 19, 371 (1956).

4. Ottolenghi, A., Bernheim, F., and Wilbir, K.M., Arch. Biockem. Biophys., 26, 157 (1955).

5. Barber, A.A., and Ottolenghi, A., Proc. Soc. Exptl. Biol. Med. , 96, 471 (1956).

6. Canzanelli, A., Sossen, R., and Rapport, D., Am. - Physicl. 188 , $547(1957)$.

7. Beyer, R.E., Arch. Biochem. Bioprys., 79, 269 (1959).

8. Wilson, I.B., "The Enzymes", V. 4, Edited by Boyer, P.D., Lardy, H. and Myrback, K., Academic Press, N.Y. and London, 1960 , Ch. 30.

9. Mendel, B., and Kudney, H., J, Biochem., 37, 59 (1943).

10.Wilson, I.B. and Bergmann, F., J. I3iol. Chen., 186, 683 (1450).

11. Wilson, I.B. and Bergmann, F., J. Biol. Chem., 182, $479(19,0)$.

12. Wilson, I.B., I. Biol. Chem., 197, 214 (1952).

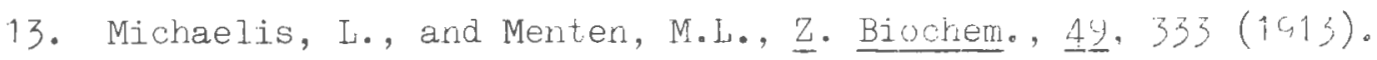

14. Lineweaver, H., and Burk, D。, J. Amər. Chem. Suc., 26, 05,8 (1974).

15. Straus, O.H., and Goldstein, A., J. Ger. Physiol., 26, 553 (194.).

16. Goldstein, A., J. Gen. Physio1., 27, 529 (1944).

17. Hunter, A., and Downs, C.E., J. Biol. Chem. 157, 427 (1945).

18. Friedenwald, J.S., and Maengwyn-Daview, G.D., "A Sympusicum on the Mechanism of Enzyme Action", McElroy, W.D., and Glass, B., Eds., Johns Hopkins Press, Baltimore, Md., 1954, p. 154 .

19. Morgan, G.T., and Drew, H.D.K. . Chem. S.e. 117, 1456 (19.0), 
20. Chaberek, S., and Martell, A.E., "Organic Sequestering Agents", John Wiley \& Sons, Inc., N.Y., 1959, Ch. 1.

21. Schwarzenbach, G., and Ackermann, H., Helv. Chim. Acta, 30, 1798 (1947).

22. Schwarzenbach, G., and Biedermann, W., Helv. Chim. Acta, 31 , 459 (1948).

23. Schwarzenbach, G., and Ackermann, H., Helv. Chim. Acta, 31 , 1029 (1948).

24. Chaberek, S., and Martell, A.E., J. Am. Chem. Soc., 74, 5052 (1952).

25. Ackermann, H., and Schwarzenbach, G., Helv. Chim. Acte, 32, 1543, (1949).

26. Carlson, G.A., McReynolds, J.P., and Verhoek, F.H., J. Am. Chem. Soc. 67, 1334 (1945).

27. Schwarzenbach, G., and Biedermann, R., Helv. Chim. Acta., 31, 331 (1948).

28. Schwarzenbach, G., Ackermann, H., and Ruckstuhl, P., Helv. Chim. Acta, 32, 1175 (1949).

29. Bjerrum, J., "Metal Ammine Formation in Aqueous Solution", P. Hasse \& Son, Copenhagen, 1942.

30. Bolton, S.M., and Beckett, A., J. Pharm. Sci., 53, 55 (1964).

31. Wagner-Jauregg, T., Hackley, B.E., Jr., Lies, T.A., Owens, O.D., and Proper, R., J. Am. Chem. Soc., 77, 922 (1955).

32. Courtney, R.C., Gustafson, R.L., Westerback, S.J., Hytiainen, H., Chabarek, S., and Martell, A.E., J. Am. Chem. Soc., 79, 3030 (1957).

33. Wilson, I.B., Ginsburg, S., and Quan, C., Arch. Biochem. Biophys., 77, 286 (1958).

34. Bolton, S.M., and Ellin, R.I., J. Pharm. Sci., 51, 533 (1962).

35. Bolton, S.M., J. Pharm. Sci., 54, 373 (1965).

36. Chaberek, S., and Marte11, A., "Organic Sequestering Agents", John Wiley \& Sons, Inc. New York, 1959.

37. Bolton, S.M., J. Pharm. Sci., 54, 583 (1965). 
38. Breckenridge, J.G., and Hodgirs, J.W.R., Carı.J. Research, 17B, 331 (1939)。

39. Gonick, E., Doctoral Dissertation, The Perınsylvania State College (1951).

40. Mario, E., and Bolton, S.M., Anal. Chen., 37, 165 (1965).

41. Schwarzenbach, G., Maissen, B., and Ackermanr, H., Helv. Chim. Acta, 35, 2333 (1952).

42. Albert, A., I. Biochem。, 50, $531(195,0)$.

43. Li, N.C., and Doody, E., J. Am. Chem. Soc., I6, 221 (1954).

44. Wilsor, C.L., and Wilson, D.W. "C mpreheneive A.telytial Chemistry", p. 351, Elsevier Co., N.Y., 1960.

45. Jenkins, E.ì., Analyst, 79, $209(10,4)$.

46. Schwarzenbach, G., Maissen, B., and Ackernan, H., Helv, Chım. Acta., 35, 2333 (1952).

47. Kirk, P.L., and Suhniat, C.L.A., J. Biol. Chem., 8i, 237 (1929).

48. Job, P., Ann. Chim., 9, 10, $113(1928)$.

49. Hine, J., "Physical Organic Chemistry". 2nd ed.: McGraw Hill, New York 1,662.

50. Cohr, E.J., Edsall, J.T., "Proteins, Amino Acıds, and Peptıdes", ACS Morıgraph, Rheinhold, New York, 1362.

51. Taft, R.W., "Steric Effects ir Organic Chenistry", Wi]ey d Sons, New York, 1956.

52. Bertsch, C.R., Fernelius, W.C., Block, B.F., J. Ehys. Crem. 62, 444-50 (1958).

53. Ibid, pp. 503-4.

54. Hares, G.B., Doctoral Dissertatıon, four, itate Coli, 14,2. 
A P P ENDIX 
APPENDIX A

Multiple Regression Approach (ACH)

The equation used to deternine the curstants describing the inhibition is of the following form:

$$
1 / V_{0}=1 / V_{m}+\frac{K_{S}}{V_{m}}(1 / S)+1 / K_{I} V_{m}(I)+\frac{K_{S}}{K_{I} V_{I n}}\left(\frac{I}{S}\right)
$$

This may be rewritten for convenience as follows:

$$
\begin{aligned}
& y=a+b x+c r+d w \\
& \text { where } a=1 / v_{m}, b=\frac{K_{s}}{V_{m}}, c=4 \quad K_{I} V_{m}, a=\frac{K_{K}}{K_{L} V_{m}} .
\end{aligned}
$$

Considering $y$ as a linear function of $x, z$, and $w$, the usual least squares multiple regression approach can be used to obtain the best estimates of $a, b, c$, and $d$.

The normal equations are:

$$
\begin{aligned}
& (y-\bar{y}) x=b(x-\bar{x})^{2}+c x(z-\bar{z})^{2}+d x(w-\bar{w})^{2} \\
& (y-\bar{y}) z=b \quad(x-\bar{x}) z+c(z-\bar{z})^{2}+d \quad(w-\bar{w}) z \\
& (y-\bar{y}) w=b \quad(x-\bar{x}) w+c \quad(z-\bar{z}) w+a \quad(w-\bar{w})^{2} \\
& (\mathrm{x}-\mathrm{x}) \mathrm{z}=0 \text { in the present case. }
\end{aligned}
$$

Using the data of Table VI, the followint: estinates were obtained:
$a=41.9$
$b=8.00 \times 10^{-3}$
$c=5.57 \times 10^{2}$
$d=1.15$

Solving for the approximate constants, we obtair;

$$
1 / \mathrm{V}_{\mathrm{m}}=41.9 \quad \mathrm{~K}_{\mathrm{S}}=1.91 \times 10^{-4} \quad \mathrm{~K}_{\mathrm{I}}=6.95 \times 10^{-3} \quad \propto=10.8
$$




\section{APPENDIX B}

Fortran IV Listing for Quadratic Solution

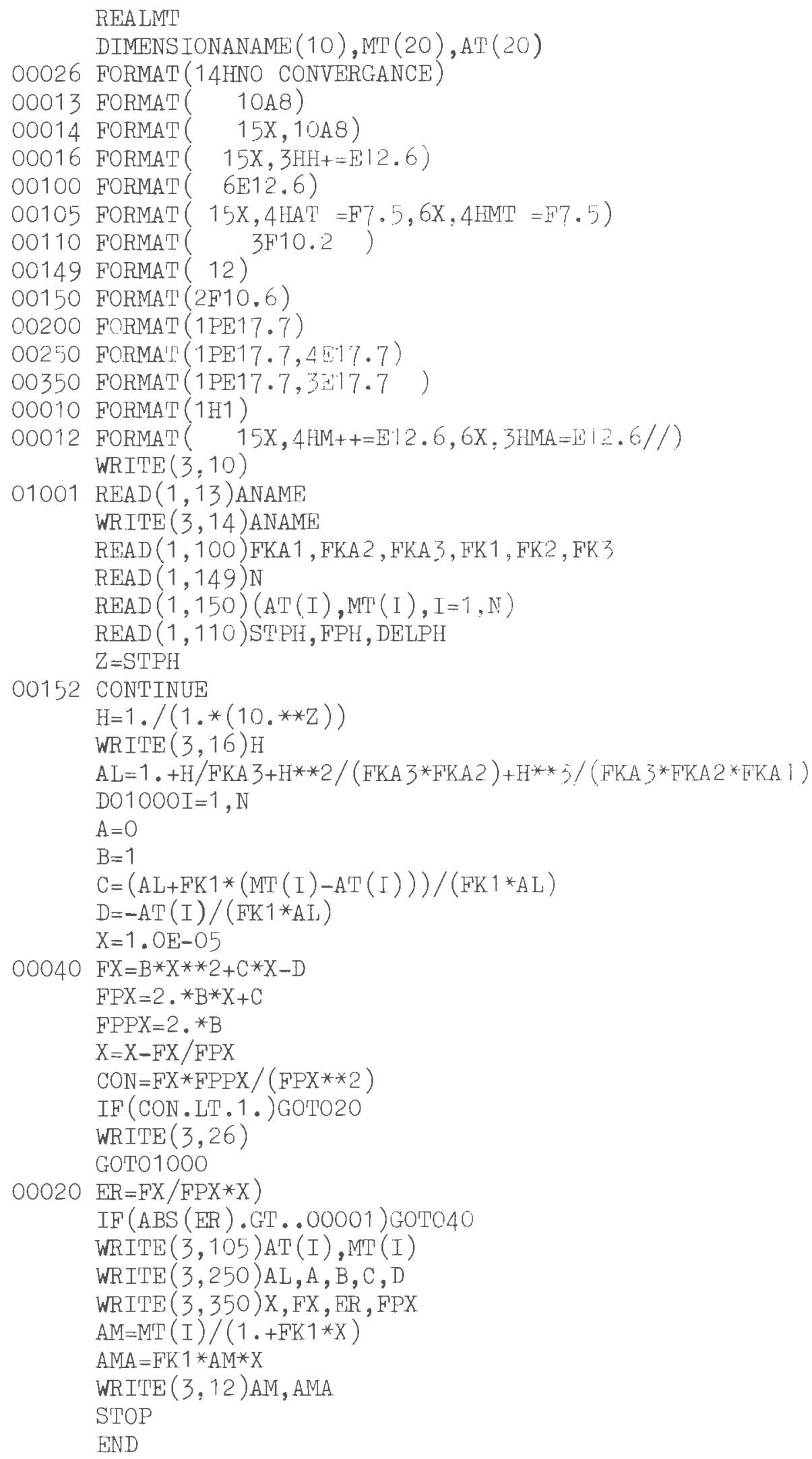




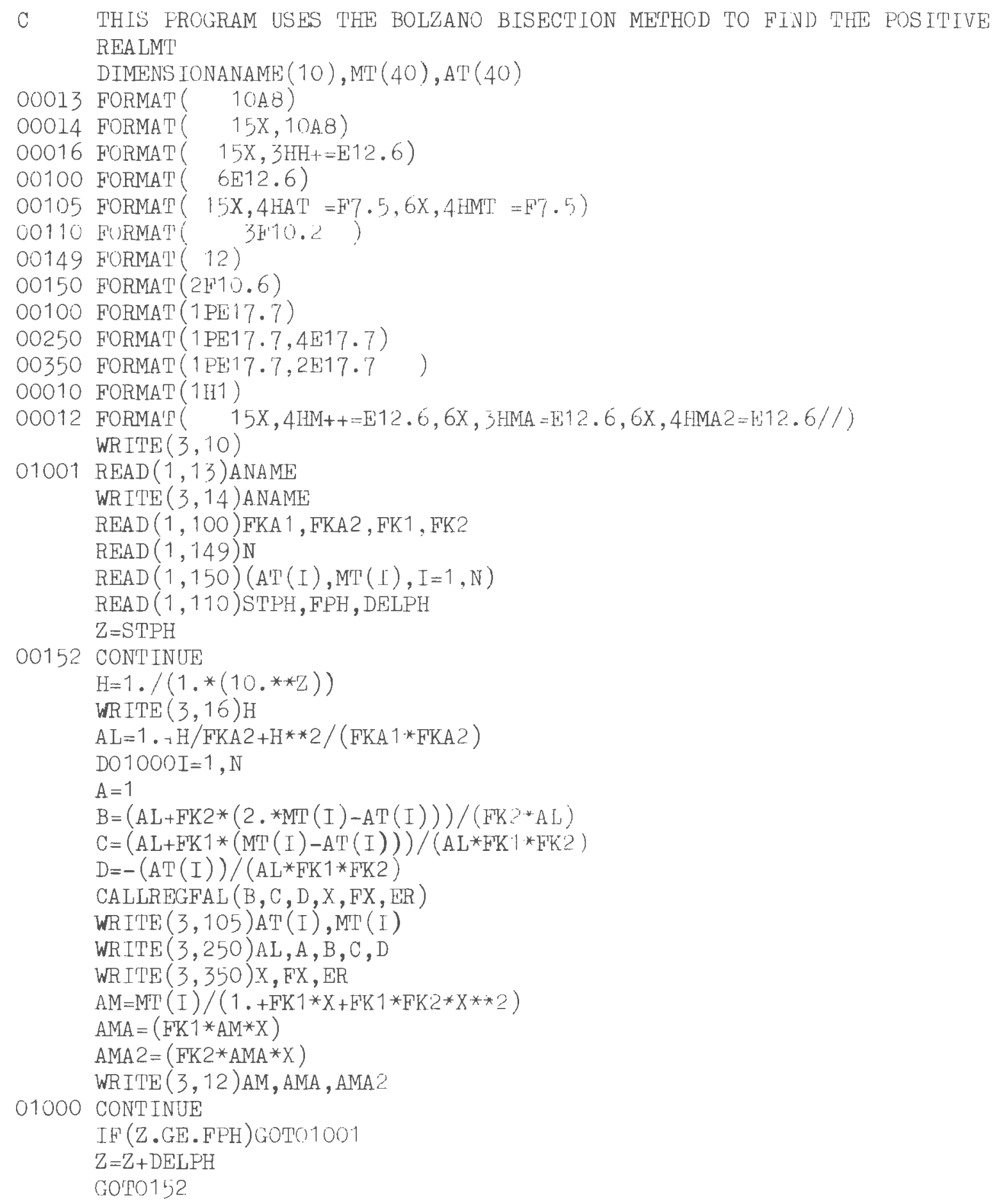




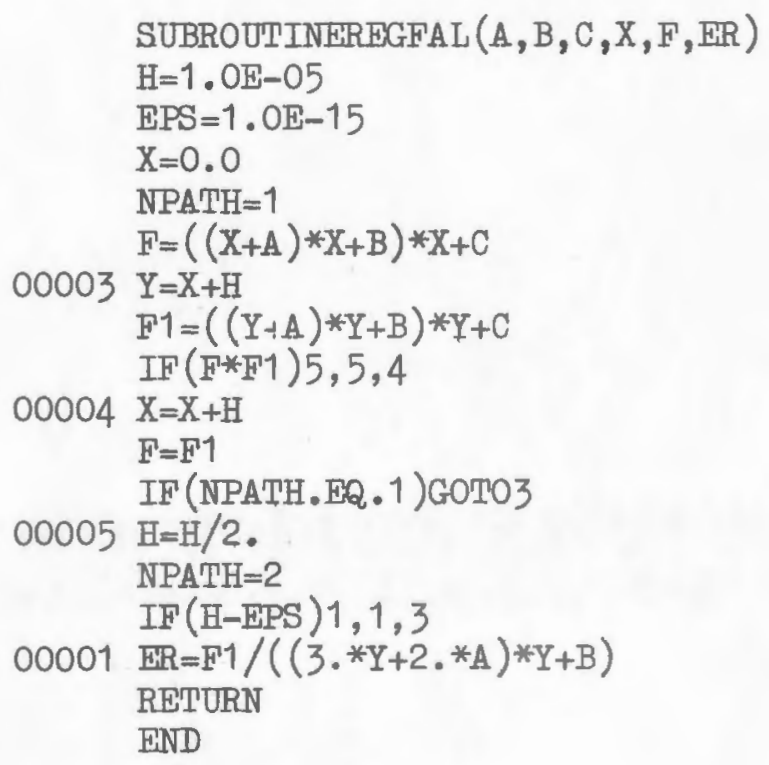


$\alpha$ Determinations According to the Method Described by MaengwynDavies and Friendenwald (18)

The Michaelis-Menten theory is based on the assumption that the enzyme forms reversibly dissociable complexes with substrate, activator, and inhibitor. Equilibrium of such complex formation is presumed to be reached instantaneously. The theory in its simplest form is established by the following argument: (a) The total concentration $\left(\mathrm{F}_{\mathrm{T}}\right)$ of potentially active enzymatic Loci for a given enzyme can be expressed as the sum of the concentrations of those Loci that are coupled with substrate (ES) and those not so coupled (E).

$$
\left(\mathbb{T}_{T}\right)=(E S)+(E)
$$

(b) The velocity $\mathrm{V}$ of enzymatic catalysis is proportional to the concentration of the enzyme-substrate complex (ES) and reaches a maximum $V_{m}$ when all available enzyme Loci are so coupled.

$$
V \sim(E S) \quad \frac{V}{V_{m}}=\frac{(E S)}{\left(E_{T}\right)}
$$

(c) The enzywe-substrate coupling is a reversible association, subject to first-order mass law equation:

$$
(\mathrm{ES}) \rightleftharpoons(\mathrm{E})+(\mathrm{S}) \quad \mathrm{K}_{\mathrm{s}}=\frac{(\mathrm{E})(\mathrm{S})}{(\mathrm{ES})}
$$

Using these assumptions, Michaelis-Menten obtained the equation: 


$$
\frac{V_{m}}{V}=\frac{(E T)}{(E S)}=1+\frac{K_{S}}{(S)}
$$

Lineweaver and Burk pointed out that this equation is linear for $1 / \mathrm{V}$ versus $1 / \mathrm{S}$ when the theory is applicable. The intercept of this line with the $1 / \mathrm{S}$ axis occurs at the point having the numerical value $-1 / \mathrm{K}_{\mathrm{s}}$.

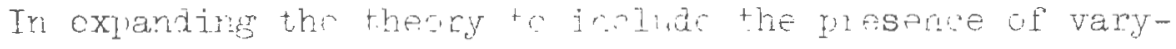
ing amounts ot a dissuciable irriltitor, t!e tital enzyme (it equals:

$$
\left(E_{\mathrm{T}}\right)=(\mathrm{E})+(\mathrm{ES})+(\mathrm{EI})+(\mathrm{EIS})
$$

Applying mass action theory to the various possuble dissociations, one obtains:

$$
\begin{aligned}
& (\mathrm{ES}) \rightleftharpoons(\mathrm{E})+(\mathrm{S}) \quad \mathrm{K}_{\mathrm{S}}=\frac{(\mathrm{E})(\mathrm{S})}{(\mathrm{ES})} \quad(\mathrm{E})=(\mathrm{ES}) \frac{\mathrm{K}}{\mathrm{S}} \\
& (E I) \rightleftharpoons(E)+(I) \quad K_{T}=\frac{(E)(I)}{(E I)} \\
& (\mathrm{EI})=(\mathrm{E}) \frac{(\mathrm{I})}{\mathrm{K}_{I}}=(\mathrm{ES}) \frac{(\mathrm{I}) \mathrm{K}_{\mathrm{S}}}{(\mathrm{S}) \mathrm{K}_{\perp}} \\
& (E I S) \Longrightarrow(E I)+(S) \quad \alpha K_{S}=\frac{(E I)(S)}{(E I S)} \quad(E I S)=(E I) \frac{(S)}{\alpha K_{S}}=E S \frac{(I)}{\alpha K_{I}} \\
& (\mathrm{EIS}) \rightleftharpoons(\mathrm{ES})+(\mathrm{I}) \quad \beta \mathrm{K}_{\mathrm{I}}=\frac{(\mathrm{ES})(\mathrm{I})}{(\mathrm{EIS})} \quad(\mathrm{EIS})=\mathrm{ES} \frac{(\mathrm{I})}{\beta \mathrm{K}_{\mathrm{I}}}
\end{aligned}
$$

The evaluation of $\alpha$ can be done as follows:

Substituting into the right-hard side of Equation b, the valuss 
indicated in Equations 6 to 9 yields:

$$
\begin{aligned}
& \frac{V_{m}}{V}=\frac{\left(E_{T}\right)}{(\mathrm{ES})}=1+\frac{K_{g}}{(S)}+\frac{(I) K_{S}}{(S) K_{I}}+\frac{1}{\alpha K_{I}} \\
& \frac{V_{m}}{V}=\frac{\left(E_{T}\right)}{(E S)}=\left[1+\frac{(I)}{\alpha K_{I}}\right]\left[1+\frac{\alpha K_{s}}{(S)} \cdot \frac{(I)+K_{I}}{(I)+\alpha K_{I}}\right] \\
& =\left[1+\frac{\mathrm{K}_{\mathrm{g}}}{(\mathrm{S})}\right]\left[1+\frac{(\mathrm{I})}{\alpha \mathrm{K}_{I}} \cdot \frac{(\mathrm{S})+\alpha \mathrm{K}_{\mathrm{S}}}{(\mathrm{S})+\bar{K}_{\mathrm{S}}}\right]
\end{aligned}
$$

When $(I)=0$, Equation 10 reduces to that of Michaelis-Menten:

$$
\frac{V_{m}}{V}=\frac{\left(E_{T}\right)}{(E S)}=1+\frac{K_{g}}{(S)}
$$

When (I) is constant, Equation 10 is linear in $1 / v$ versus $1 / \mathrm{s}$. From Equation (10b) it can be seen that for constant (S) the Equation is linear for $1 / T$ versus (I). The first test of the applicability of the theory to a particular set of data consists in the demonstration of these linearities.
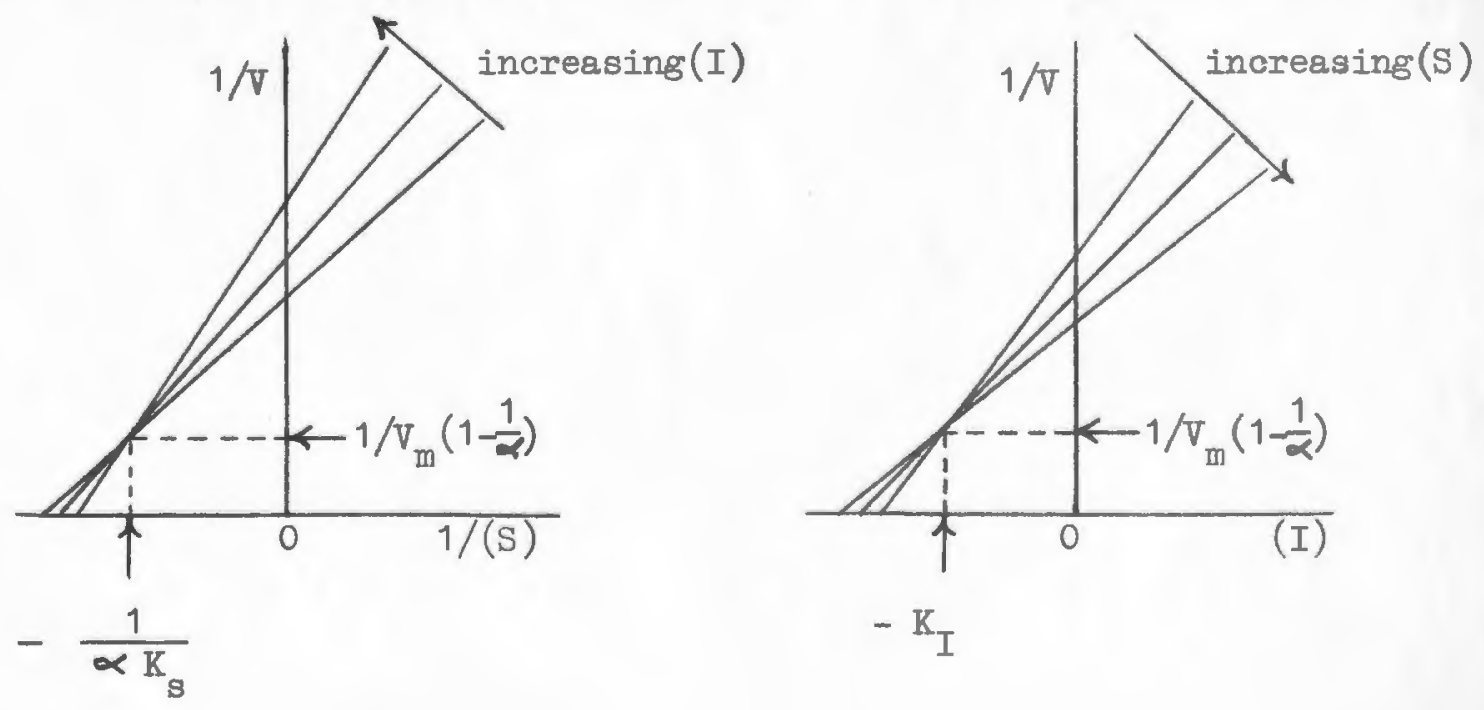
Consider two arbitrary values of inhibitor concentration $\left(I_{1}\right)$ and $\left(I_{2}\right)$. Either of these, inserted into Equation 10, yields a linear equation in $1 / \mathrm{T}$ versus $1 /(\mathrm{s})$. If we equate the righthand sides of these equations with each other and solve for (S), we will obtain the value of (S) corresponding to the intersection.

$$
\begin{aligned}
1+\frac{\mathrm{K}_{\mathrm{S}}}{(\mathrm{S})}+\frac{\left(I_{1}\right) \mathrm{K}_{\mathrm{g}}}{(\mathrm{S}) \mathrm{K}_{I}}+\frac{\left(I_{1}\right)}{\alpha \mathrm{K}_{I}}=1+\frac{\mathrm{K}_{\mathrm{S}}}{(\mathrm{S})}+\frac{\left(I_{2}\right) \mathrm{K}_{\mathrm{S}}}{(\mathrm{S}) \mathrm{K}_{I}}+\frac{\left(I_{2}\right)}{\alpha \mathrm{K}_{I}} \\
\\
\frac{\left(I_{1}\right)}{\mathrm{K}_{I}}\left[\frac{\mathrm{K}_{\mathrm{S}}}{(\mathrm{S})}+\frac{1}{\alpha}\right]=\frac{\left(I_{2}\right)}{\mathrm{K}_{I}}\left[\frac{\mathrm{K}_{\mathrm{S}}}{(\mathrm{S})}+\frac{1}{\alpha}\right]
\end{aligned}
$$

Since $\left(I_{1}\right)$ and $\left(I_{2}\right)$ are arbitrarily chosen and $K_{I}$ is not infinite, it follows that at the intersection:

$$
\frac{K_{s}}{(s)}+\frac{1}{\alpha}=0
$$

And,

$$
1 /(\mathrm{s})=-\frac{1}{\alpha \overline{\mathrm{K}}_{\mathrm{s}}} ; 1 / \mathrm{V}=1 / \mathrm{V}_{\mathrm{m}}\left[1-\frac{1}{\alpha}\right]
$$

The intersection is independent of (I), consequently, the family of lines meet in a point.

Similarly, on the $1 / \mathrm{N}$ versus (I) plot, the family of lines corresponding to different fixed values of (S) will also meet in a point $(I)=-\mathrm{K}_{I} ; 1 / V=1 / V_{m}\left(1 \frac{1}{\alpha}\right)$. From these two intersections together with a lineweaver-Burk plot in the absence of inhibitor, all four constants: $\mathrm{K}_{\mathrm{s}}, \mathrm{K}_{\mathrm{I}}, \alpha$, and $\mathrm{V}_{\mathrm{m}}$ can be evaluated. For 
the special cases $\alpha=1$ and $\alpha=\infty$, i.e., for perfectly noncompetitive and perfectly competitive inhibition, the intersections on both plots are shown in the following examples:

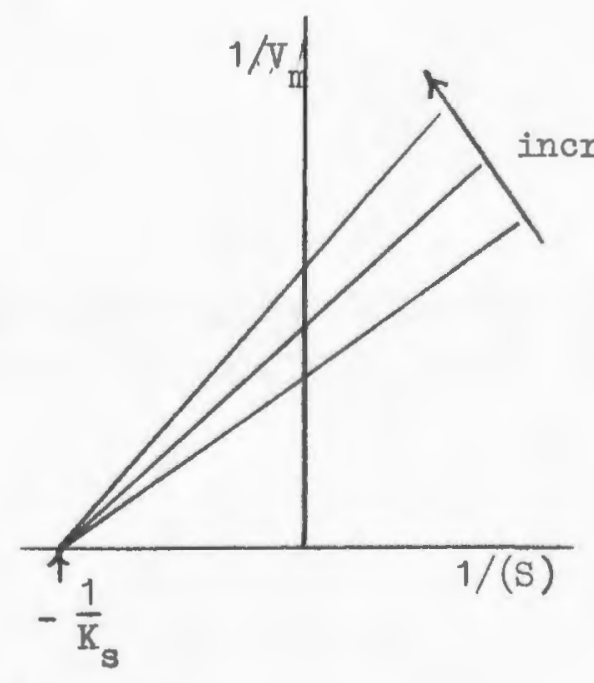

Non-competitive $\prec=1$

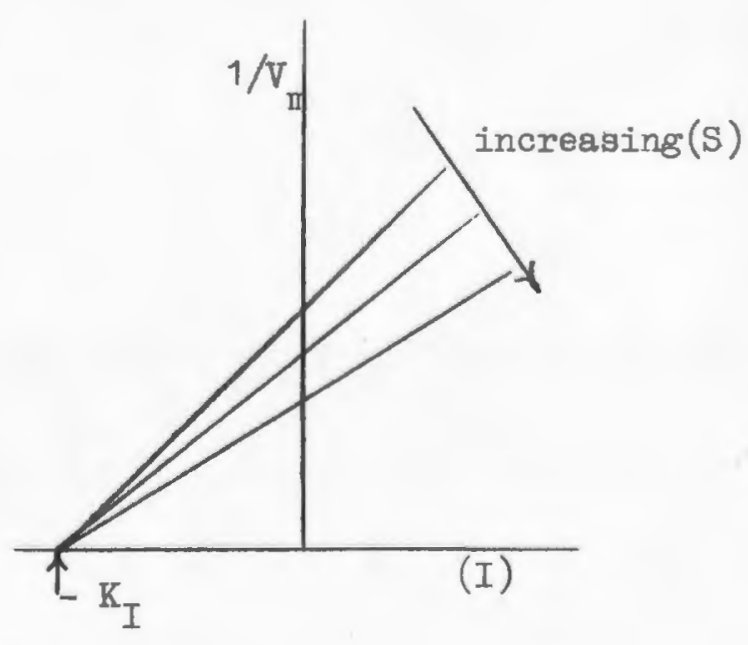

Non-competitive $\alpha=1$

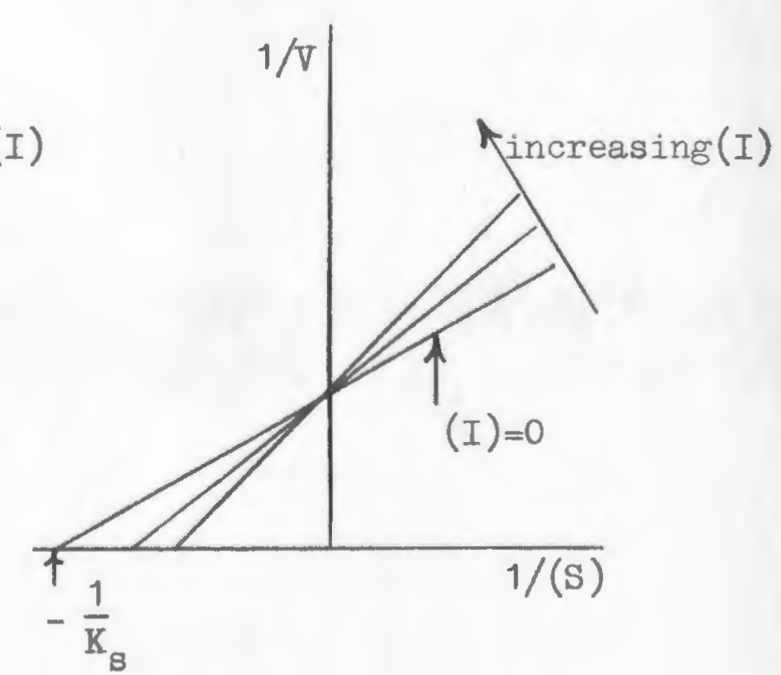

Competitive $\alpha=\infty$.

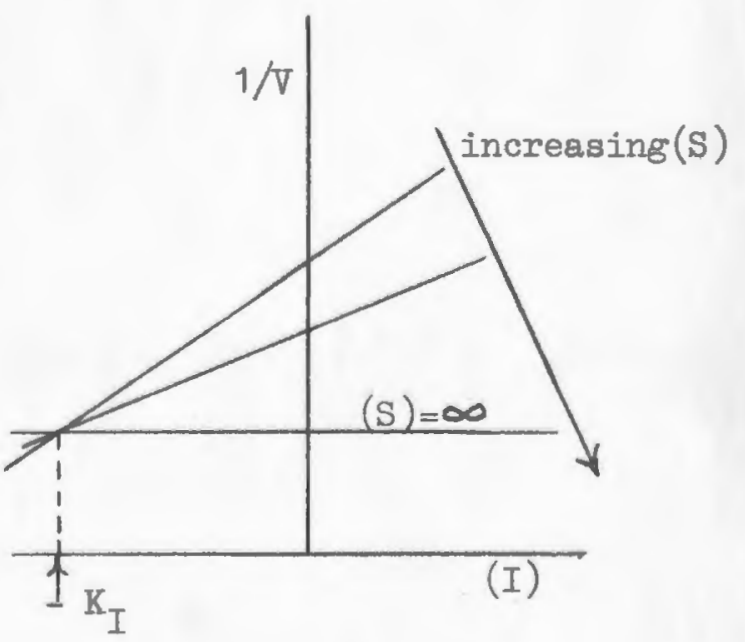

Competitive $\alpha=\infty$. 
Solving for $\mathrm{K}_{2}$ in terms of $\mathrm{K}_{1}$

$$
K_{2}=\frac{1}{(I)} \cdot \frac{(\bar{n}-1)+\frac{\bar{n}}{K_{1}(I)}}{(2-\bar{n})}
$$

Using a $\mathrm{K}_{2}$ value of $1.41 \times 10^{7}$ obtained from the data at $\bar{n}=1.5$, a value for $K_{1}$ is calculated. This $K_{1}$ value is then used to reestimate $\mathrm{K}_{2}$ and the method is continued until consistent values for $\mathrm{K}_{1}$ and $\mathrm{K}_{2}$ are obtained. After repeated calculations, $\mathrm{K}_{1}=7.60 \times 10^{8}$ and $\mathrm{K}_{2}=1.63 \times 10^{7}$ yielded fairly consistent results. Since the data is not exact, $\bar{n}$ is calculated at various free ligand values and compared to observed $\bar{n}$ values. The following tabulation contains the results of this check method and indicates that the values of $\mathrm{K}_{1}$ and $\mathrm{K}_{2}$ found are ressonably accurate.
Calculated $\bar{n}$
Observed $\bar{n}$.
Free Ligand
0.342
0.303
$6.67 \times 10^{-10}$
0.392
0.383
$8.31 \times 10^{-10}$
0.462
0.461
$1.07 \times 10^{-9}$
0.531
0.593
$1.39 \times 10^{-9}$
1.120
1.061
$1.51 \times 10^{-8}$
1.286
1.314
$3.72 \times 10^{-8}$
1.510
1.504
$6.75 \times 10^{-8}$
1.600
1.602
$9.37 \times 10^{-8}$ 